\author{
UNIVERSIDADE DE SÃO PAULO \\ ESCOLA DE COMUNICAÇÕES E ARTES \\ Mestrado em Música
}

\title{
A PESQUISA EM PRÁTICAS INTERPRETATIVAS: \\ ESTUDOS RECENTES NAS \\ UNIVERSIDADES ESTADUAIS PAULISTAS
}

\section{CLÁUDIA ELENA SISTE}

SÃO PAULO

2009 
ESCOLA DE COMUNICAÇÕES E ARTES

Mestrado em Música

\title{
A PESQUISA EM PRÁTICAS INTERPRETATIVAS:
}

\author{
ESTUDOS RECENTES NAS
}

UNIVERSIDADES ESTADUAIS PAULISTAS

\section{CLÁUDIA ELENA SISTE}

Dissertação apresentada ao Programa de PósGraduação em Música, Área de Concentração Processos de Criação Musical, Linha de Pesquisa Técnicas Composicionais e Questões Interpretativas, da Escola de Comunicações e Artes da Universidade de São Paulo, como exigência parcial para a obtenção do Título de Mestre em Música, sob a orientação do Prof. Dr. Eduardo Henrique Soares Monteiro.

SÃO PAULO 
Cláudia Elena Siste

\section{A PESQUISA EM PRÁTICAS INTERPRETATIVAS: \\ ESTUDOS RECENTES NAS \\ UNIVERSIDADES ESTADUAIS PAULISTAS}

Banca Julgadora:

Prof. Dr. Eduardo Henrique Soares Monteiro 
Aos meus pais,

Maria Neusa e Paulo.

Aos meus irmãos,

Carlos Eduardo, Maria Lúcia e Maria Laura.

Ao Sérgio. 


\section{Agradecimentos}

Ao meu orientador, Prof. Dr. Eduardo Henrique Soares Monteiro, pelo aprendizado que proporcionou-me ao orientar este trabalho e pela confiança em mim depositada desde o primeiro momento.

À Prof ${ }^{a}$ Dr $^{\mathrm{a}}$ Flávia Camargo Toni, pelo apoio e sugestões críticas.

À Prof ${ }^{a} \operatorname{Dr}^{\mathrm{a}}$ Luciana Sayure Shimabuco, pelo apoio e sugestões críticas.

Aos Professores Doutores Dorotéa Machado Kerr, Fernando Henrique de Oliveira Iazzetta e Adriana Giarola Kayama, pelas entrevistas que gentilmente concederam.

À Prof ${ }^{a}$ Deise Aparecida Martineli de Assumpção, pela revisão ortográfica e sugestões críticas. 


\section{RESUMO}

Esta pesquisa tem como objetivo investigar e traçar o perfil dos trabalhos referentes a Práticas Interpretativas, no contexto dos cursos de pós-graduação stricto sensu em Música, das universidades estaduais paulistas.

Considera a forma de inserção de Práticas Interpretativas na estrutura dos programas dos referidos cursos, bem como o histórico da implantação dos programas, e analisa uma amostragem da produção acadêmica resultante, no período de 2002 a 2007, buscando estabelecer as tendências quanto a objeto de estudo e procedimentos metodológicos. Entre os procedimentos, procura demonstrar como e até que ponto a análise do material musical está sendo utilizada como ferramenta em prol da interpretação, bem como a escolha de abordagens mais apropriadas à especificidade das Práticas Interpretativas. Faz alusão, portanto, às discussões sobre as relações que podem se estabelecer entre interpretação e análise musical.

Constata encontrar-se o segmento de Práticas Interpretativas ainda em processo de consolidação entre as áreas de concentração e linhas de pesquisa dos programas, e, por outro lado, a existência de uma produção significativa e crescente, a validar e acelerar essa consolidação.

Palavras-chave: música, práticas interpretativas, performance, programas de pós-graduação em música, interpretação. 


\begin{abstract}
The objective of this study is to examine and outline Performance Practices studies carried out in stricto sensu graduate music courses in State funded universities in the State of São Paulo.

It looks at the place attributed to Performance Practices in the curricula of such courses and the historic development thereof, analyzing a sample of the resulting research and publications between 2002 and 2007, and trying to establish existing trends between the study object and methodological procedures. Within the context of procedures, the work attempts at demonstrating how and in how far the musical material employed is being used as a tool favoring interpretation, as well as choosing more appropriate approaches considering the specificity of Performance Practices. It refers therefore to the discussion about the relationship that may exist between interpretation and musical analysis.

It can be said that the Performance Practices segment is still in a process of consolidating the main areas of studies and research, and on the other hand there is clear evidence of significant and growing production thus validating and accelerating the consolidation process.
\end{abstract}

Key words: music, performance practices, performance, graduate programs in music, interpretation. 


\section{SUMÁRIO}

INTRODUÇÃO

CAPÍTULO 1

1.1 - O início e o papel das agências de fomento

1.2 - Áreas de Concentração e Linhas de Pesquisa 06

1.3 - Implantação e Desafios 08

1.3.1 - Musicologia e Teoria Musical

1.3.2 - Educação Musical e Composição 12

1.3.3 - Práticas Interpretativas

1.4 - Áreas de Concentração e Linhas de Pesquisa nos Programas de Pós-Graduação em Música das universidades estaduais paulistas

2.1 - O registro da prática

2.2 - Registro e reconhecimento acadêmico

2.3 - O status do instrumentista

2.4 - Iniciativas e publicações

3.1 - Análises dos trabalhos selecionados

3.1.1 - Universidade de São Paulo - USP

3.1.1.1 - O Salmo 150 de Ernst Mahle questões composicionais e interpretativas 
3.1.1.2 - Radamés Gnattali: "Suíte para Quinteto de Sopros" -

Estudo Analítico e Interpretativo

3.1.1.3 - Missa Ferial de Osvaldo Lacerda -

Uma Análise Interpretativa

3.1.2 - Universidade Estadual Paulista - UNESP

3.1.2.1 - Os fundamentos da interpretação musical: aplicabilidade nos 12 Estudos para Violão de Francisco Mignone

3.1.2.2 - Análise rítmico-prosódica como ferramenta para a performance da canção: um estudo sobre as canções de câmara de Claudio Santoro e Vinícius de Moraes

3.1.2.3 - As miniaturas musicais de Nilson Lombardi

3.1.3.1 - A escrita para viola nas Sonatas com piano op. $11 \mathrm{n}^{\circ} 4$ e op. $25 n^{\circ} 4$ de Paul Hindemith: aspectos idiomáticos, estilísticos e interpretativos

3.1.3.2 - Almeida Prado: estudos para piano, aspectos técnico-interpretativos

3.1.3.3 - Questões estruturais e interpretativas na obra pianística de Ricardo Tacuchian 
ANEXOS

Anexo I

87

Anexo II

96

Anexo III

111 


\section{INTRODUÇÃO}

A introdução das Artes e da Música no meio acadêmico sempre suscitou questionamentos. Talvez pela recorrente questão acerca de uma "utilidade" que a sociedade extremamente prática e imediatista em que se vive cobra dessas áreas, talvez pelo fato de que o conhecimento nelas engendrado pode aparentar ser mais difuso, ou talvez, apenas, por lidar com mecanismos menos ainda explicados de nossa própria existência, fato é que os cursos de Arte e os de Música foram mais tardiamente absorvidos, nos meios universitários, do que cursos como Direito, Medicina ou Engenharia.

Conseqüentemente, também os cursos de pós-graduação em Artes e em Música demoraram a instalar-se.

E, dentre os programas de pós-graduação em Música, a área de Práticas Interpretativas tem sido também uma das últimas a obter formalização definitiva, sucedendo, com certo atraso, a áreas como a Musicologia, de caráter histórico, ou a Educação Musical, ou mesmo às áreas de Teoria e Análise Musical.

Esta realidade, que demonstraremos em nosso presente trabalho, não se apresenta como um fato isolado, acontecido casual ou fortuitamente, mas revela como o conceito de conhecimento e a aceitação de modelos diversos para a aquisição do conhecimento vêm tendo seus horizontes ampliados.

Seja a aceitação da importância das Artes no seio da sociedade, seja a importância da própria Música entre as Artes, seja a aceitação da importância de determinadas áreas da Música entre os próprios músicos, o que parece estar em jogo é sempre o reconhecimento de que a diversidade pode ser benéfica, mesmo quando a ampliação do quadro não se refere ao nosso paradigma de conhecimentos e reconhecimentos, de experiências prévias. Está em pauta, sempre, vencer preconceitos.

Por tratar de questões mais próximas (mas não exclusivas) da realidade dos intérpretes, cuja produção bibliográfica parece ter sido menos volumosa, especialmente nos tempos que precederam a criação dos programas de pós-graduação em Música, a área de Práticas Interpretativas parece estar, ainda hoje, à procura de determinadas respostas que outras áreas já obtiveram, ou seja, ainda discute seu papel e o perfil que 
pode construir nos programas de pós-graduação, nos departamentos de música, nas universidades.

Foi a partir destas reflexões que nosso projeto se originou, e resolvemos, pois, dedicarmo-nos a este tema.

A abrangência do objeto de nosso estudo foi circunscrita às universidades estaduais paulistas, já que tratar da realidade do país como um todo, ou mesmo de uma região brasileira, seria tarefa extensa demais, incompatível com uma proposta de mestrado. Caso propuséssemos uma abrangência maior, haveria o risco de menor detalhamento. O recorte que efetuamos, no entanto, não deixará de considerar o contexto da realidade brasileira em que se insere. Sem isso, tal recorte não seria possível.

Com este intuito, o primeiro capítulo fornece uma visão geral do histórico do surgimento dos programas de pós-graduação stricto sensu em Música no Brasil, destacando o papel das agências de fomento nesse processo e da ANPPOM Associação Nacional de Pesquisa e Pós-Graduação em Música. Buscamos desenvolver nele os desafios que se estabeleceram desde o princípio quanto à introdução das Artes, em geral, e da Música, em especial, no meio acadêmico, principalmente tratando-se de Práticas Interpretativas.

Os conceitos relativos a "Área de Concentração" e "Linha de Pesquisa", em torno dos quais se estruturam os programas de Pós-Graduação, serão delineados, e os parâmetros sobre os quais nos debruçamos são aqueles fornecidos pela Coordenação de Aperfeiçoamento de Pessoal de Nível Superior (CAPES), que acompanha e avalia os cursos de pós-graduação stricto sensu no Brasil. Apresentaremos uma visão geral da estrutura dos programas nas três universidades estaduais paulistas, transcrevendo-os tal como oficialmente expostos pelas universidades.

Três entrevistas realizadas com docentes das universidades a que se atém o trabalho, e que atuaram como coordenadores em momentos importantes da história dos programas, ajudarão a compor o quadro. Fornecerão informações sobre o funcionamento dos mesmos e auxiliarão na compreensão dos elementos e condições que contribuíram para sua instalação dentro de uma determinada estrutura, bem como irão traçar um perfil da estrutura atual. As valiosas entrevistas que estes docentes nos concederam estão reproduzidas integralmente nos documentos anexos. 
No segundo capítulo, temos uma reflexão acerca dos desafios e dificuldades que enfrentam as Práticas Interpretativas no contexto da pós-graduação. Estas reflexões estão baseadas em artigos que tratam diretamente do assunto. Neles, são abordados os preconceitos e resistências que envolvem a pesquisa nessa subárea, decorrentes e compatíveis com a polêmica em torno da relação entre teoria e prática, pesquisa e prática interpretativa, e a questão do registro acerca das práticas interpretativas. Considera-se que essa polêmica acabou por desencadear esforços e iniciativas importantes relacionados à questão, como encontros, simpósios, publicações, formação de grupos de pesquisa.

Em nosso terceiro capítulo, relacionamos e tecemos considerações sobre nove trabalhos: três dissertações de Mestrado apresentadas ao Departamento de Música da Universidade de São Paulo (USP), três dissertações de Mestrado apresentadas à Universidade Estadual Paulista (UNESP), e uma tese de Doutorado e duas dissertações de Mestrado apresentadas à Universidade Estadual de Campinas (UNICAMP), abarcando o período de 2002 a 2007. O critério para a seleção destes nove trabalhos está exposto na introdução do próprio capítulo.

Por meio desta amostragem, intentamos promover uma análise e comentários sobre a maneira como se tem realizado a abordagem das Práticas Interpretativas em pesquisas realizadas, recentemente, em nível de Mestrado e Doutorado, nas universidades estaduais paulistas. O objetivo aqui não será criticar os trabalhos, mas tão somente apontar tendências, constatar a presença desse importante aspecto dos estudos musicais no meio acadêmico, desvendar a relação que vai se estabelecendo entre análise e interpretação.

$\mathrm{Na}$ conclusão, demonstraremos, retomando os dados levantados nos capítulos, a relevância dos mesmos para um esboço da realidade com que nos deparamos atualmente quanto à inserção de Práticas Interpretativas no cenário das pesquisas acadêmicas em Música, realidade essa decorrente de todo um processo iniciado, relativamente, há pouco tempo. Nesse quadro, pretende-se fornecer uma visão geral do processo de inclusão do referido seguimento nos programas de pós-graduação e de como se encontram atualmente inseridos na estrutura desses programas. Além disso, pretende-se também demonstrar os resultados já alcançados, que se configuram na produção de dissertações e teses. Procuraremos, pelo estudo dessas pesquisas, demonstrar a maneira como o tópico Práticas Interpretativas tem sido abordado. A referida intenção de não se fazer juízo de valor não implica que não se façam considerações sobre formas de 
abordagem, aspectos e estratégias de caráter metodológico, aplicação de resultados de análises do material musical em propostas para a performance. Tais considerações visam demonstrar as citadas tendências e fornecer, dentro dos limites e limitações deste trabalho, elementos para uma reflexão quanto a caminhos futuros.

Cumpre notar que as conclusões foram se construindo ao longo dos capítulos e, ao final, são retomadas para proporcionar uma visão geral do que se apurou. 


\section{CAPÍTULO 1}

Neste primeiro capítulo procuraremos fornecer alguns dados históricos sobre a criação dos cursos de Pós-Graduação em Música nas universidades estaduais paulistas, quais as transformações que os programas sofreram e qual o lugar que a pesquisa em Práticas Interpretativas vem ocupando.

Faz-se necessário, porém, ter presente como se desencadeou a instalação desses cursos no país. Para isso, baseamo-nos em texto de Ilza Nogueira, encontrado nos Anais do IX Encontro Anual da Associação Nacional de Pesquisa e Pós-Graduação em Música (ANPPOM).

\section{1 - O início e o papel das agências de fomento}

Segundo Nogueira, a partir da segunda metade da década de 1970 as agências de fomento Comissão Fulbright ${ }^{1}$, Associação LASPAU ${ }^{2}$ e Fundação CAPES (Coordenação de Aperfeiçoamento de Pessoal de Nível Superior) investiram na formação de recursos humanos em Música em universidades dos Estados Unidos. No entanto, os primeiros cursos de Mestrado em Música no país, instalados na Universidade Federal do Rio de Janeiro (UFRJ) em 1980 e no Conservatório Brasileiro de Música em 1982, não foram fruto desse investimento das agências em formação de doutores no exterior. Somente em 1987, com a criação do $3^{\circ}$ Mestrado em Música, na Universidade Federal do Rio Grande do Sul (UFRGS), deu-se a absorção dos primeiros doutores titulados em universidades americanas. A partir de 1990, o crescimento do número desses recémtitulados acarretou a implantação de mais três cursos: Mestrado em Música na Universidade Federal da Bahia (UFBA) em 1990, Mestrado em Música Brasileira na Universidade Federal do Estado do Rio de Janeiro (UNI-RIO) e Mestrado em Musicologia na Universidade de São Paulo (USP) em 1993. Em 1995 implanta-se o primeiro Doutorado em Música, na UFRGS. (NOGUEIRA, 1996, p. 40)

\footnotetext{
${ }^{1}$ FULBRIGHT (Brasil): Comissão para intercâmbio educacional entre os Estados Unidos e o Brasil.

${ }^{2}$ LASPAU - Academic and Professional Programs for the Americas - é uma organização sem fins lucrativos afiliada à Universidade de Harvard. Projeta, desenvolve e implementa programas acadêmicos e profissionais em benefício das Américas.
} 
Ainda segundo Nogueira, o início do fomento à pesquisa em Música deu-se também no final da década de 1970. A pesquisa caracterizava-se, no entanto, como uma atividade esporádica e confusa quanto à própria concepção de pesquisa. Em 1984, a Música passou a ter representação individual no Comitê Assessor de Artes do Conselho Nacional de Desenvolvimento Científico e Tecnológico (CNPq), o que constitui-se no marco inicial do desenvolvimento de uma atividade de pesquisa consistente, definida e orientada. Nos anos seguintes, a contribuição do CNPq foi de grande importância na trajetória de consolidação da área. Esse incentivo, na fase que antecedeu a criação da ANPPOM, ocorrida em 1988, caracterizou-se como estimulador, com projetos os mais distintos, que revelavam ainda uma concepção pouco definida sobre a atividade de pesquisa como estritamente vinculada à geração do conhecimento, características estas próprias de um momento inicial. A partir da sedimentação da ANPPOM em 1995, busca-se, sem comprometer o rigor na avaliação de projetos, a ampliação gradativa do número de pesquisadores bolsistas. (NOGUEIRA, 1996, p. 40-41)

Com o crescimento do número de cursos e de alunos, a questão da estruturação dos programas de Pós-Graduação foi tomando vulto. Atualmente, a referida questão figura entre os "Critérios de Implantação de Mestrado e Doutorado Acadêmico" da Fundação CAPES, instituição que acompanha e avalia os cursos de Pós-Graduação stricto sensu no Brasil. A exigência é de que haja definição e articulação das linhas de pesquisa e áreas de concentração com a proposta do Programa.

\section{2 - Áreas de Concentração e Linhas de Pesquisa}

Segundo definição da CAPES, temos que:

Área de Concentração expressa a vocação inicial ou histórica do Programa. Neste sentido, ela deve indicar, de maneira clara, a área do conhecimento à qual pertence o programa, os contornos gerais de sua especialidade na produção do conhecimento e na formação esperada. É desejável que apresente uma denominação abrangente, pois não se espera que os programas alterem sua área de concentração, a menos no caso de que venha a ser objeto de forte reestruturação. Um Programa pode ter uma ou mais áreas de concentração. 
Linhas de Pesquisa expressam a especificidade de produção de conhecimento dentro de uma área de concentração e são sustentadas, fundamentalmente, por docentes/pesquisadores do corpo permanente do programa. Portanto, as linhas de pesquisa não representam um agregado desconexo, mas devem expressar um recorte específico e bem delimitado dentro da(s) área(s) de concentração e ser em proporção adequada à dimensão e à área de competência acadêmica do corpo permanente de docentes, devendo: (a) agregar, garantindo uma distribuição equilibrada entre os docentes, os projetos de pesquisa do Programa; (b) assegurar a articulação de suas ementas com as temáticas de projetos e teses e dissertações; (c) garantir proporção adequada entre o número de projetos de pesquisa e a dimensão do corpo docente. Considerando-se que a pósgraduação stricto sensu é o espaço da pesquisa e da produção do conhecimento, espera-se que linhas, orientações, disciplinas ministradas e produtos da pesquisa estejam em íntima articulação. (CAPES, 2009)

Os pressupostos da estrutura vertical que devem guiar os programas de pósgraduação, embora maleáveis e permeáveis às mudanças necessárias, devem seguir uma linha mestra, que esteja de acordo com as premissas gerais definidas pela universidade. Guardadas as especificidades que o corpo docente de cada instituição possui, os programas devem atender às idéias unificadoras que expressam o pensamento daquela universidade. Ou seja, embora a pesquisa seja campo aberto, a ser preenchido pelas especificidades de cada área, em consonância com as tendências do corpo docente, ela também deve reportar-se aos princípios gerais que norteiam toda a produção científica.

Assim sendo, as dissertações e teses produzidas sob orientação de um determinado docente devem compor um quadro que abarca os variados interesses desse orientador em específico, dialogando inclusive com sua própria produção (é parte dela, portanto). E as pesquisas dos diversos alunos, em diálogo com as dos orientadores, compõem o quadro geral de um determinado departamento, articulando as Linhas de Pesquisa em função das Áreas de Concentração às quais se referem.

Por sua vez, estas Áreas de Concentração coadunam-se com o plano geral da Instituição (Departamento ou Escola) e da própria universidade como um todo, reafirmando o papel que esta universidade desempenha no contexto regional ou nacional. 
Isso significa que a definição das Áreas de Concentração e das Linhas de Pesquisa deve atender simultaneamente a, no mínimo, dois requisitos: integrar e alinharse ao pensamento geral da universidade, levando em conta o perfil que esta universidade possui e projeta, e representar verdadeiramente as áreas de interesse, capacidades e competências dos docentes que a executam.

Subsídios a partir de entrevistas realizadas com docentes das três universidades paulistas, e que já atuaram como coordenadores dos respectivos programas, podem nos ajudar a entender as etapas e momentos em que surgiram os cursos de Pós-Graduação em Artes (depois, em Música) e como evoluíram para a forma atual. Será necessário delinear um pouco mais as premissas que nortearam a criação destes programas de pósgraduação, bem como as dificuldades enfrentadas nesse processo. Os docentes escolhidos são: $\operatorname{Prof}^{a} \operatorname{Dr}^{a}$ Dorotéa Machado Kerr (UNESP), $\operatorname{Prof}^{a} \operatorname{Dr}^{a}$ Adriana Giarola Kayama (UNICAMP) e Prof. Dr. Fernando Henrique de Oliveira Iazzetta (USP). Todos foram Coordenadores dos Programas de Pós-Graduação em Música (ou em Artes) em momentos considerados importantes para nosso estudo. A transcrição das entrevistas compõe os anexos deste trabalho.

\section{3 - Implantação e Desafios}

Tudo leva a crer que a implantação dos cursos de pós-graduação em Música foi uma conquista gradual, nascida de demandas que acumularam-se ao longo do tempo, após a chegada dos cursos de graduação em música nas universidades.

Sendo a universidade o espaço adequado para a produção do conhecimento, primeiramente não estavam incluídas, em seus cursos de graduação, as áreas ditas "artísticas". De certa maneira, as artes foram vistas como um tipo específico de prática, que não se coadunava, a priori, com os postulados das ciências exatas ou biológicas, e nem mesmo com os das ciências humanas.

A chegada dos cursos de graduação em música representa o momento em que a sociedade e, por extensão, a universidade começam a entender o significado do papel que as artes e a música possuem do ponto de vista de um conhecimento específico, próprio. Reconhecer que há conhecimento nas práticas artísticas significou uma mudança de paradigma do que pode ser julgado conhecimento científico, podemos assim afirmar. 
Mas a chegada dos programas de pós-graduação em música não se deu diretamente, senão que foi precedida de uma importante etapa. Primeiramente, foram introduzidos os programas de pós-graduação em artes, nos quais a música convivia com as outras áreas artísticas, a saber, as artes plásticas, as artes cênicas e as artes corporais:

O Programa de Pós-Graduação em Música, na realidade, teve um embrião anterior que era o Programa de Pós-Graduação em Artes, onde tínhamos artes cênicas, artes corporais, artes plásticas e música, tudo junto. Por recomendação da CAPES, insistentes recomendações, por vários anos, a gente resolveu desmembrar a música do resto das artes. (KAYAMA, 2009)

Muito provavelmente, foi um movimento em conjunto dessas áreas (música, artes plásticas, artes cênicas, etc.), não necessariamente lideradas pela música, que proporcionou este acontecimento.

... começou como um grande Programa de Artes, que abarcava as três áreas, artes plásticas, cênicas e música, provavelmente por iniciativa das artes plásticas e das artes cênicas, e a música foi meio a reboque dessa iniciativa. Isso em 72, se não me falha a memória. E é, na verdade, o Programa na área de Artes mais antigo do Brasil. Começou com mestrado, e já nesta época existiam algumas teses [dissertações], na área de música, poucas, bem pontuais, orientadas ou por professores da ECA, da Comunicação, ou eventualmente por professores aqui da casa [CMU]. (IAZZETTA, 2009)

A citação acima revela que, unidas, as áreas poderiam ter mais força para atingir seus objetivos. Tal consideração ainda atende à questão de que, sendo recém-criados, os programas de pós-graduação em artes não possuíam, de início, uma produção docente e discente que justificasse a criação de programas em áreas específicas de imediato. Ou seja, era conveniente tanto para cada área específica (música, artes cênicas e artes plásticas) quanto para as universidades que a implantação ocorresse de maneira gradativa, podendo-se fazer "correções de rumo", se necessário.

Com o passar do tempo, os programas de pós-graduação em Artes, que possuíam Musicologia como uma das suas Áreas de Concentração, passam a ser insuficientes para abrigar todas as pesquisas relacionadas à música. 
Até 2000, mais ou menos, existia uma produção pequena, o programa continuava chamando-se Programa de Pós-Graduação em Artes, com três Áreas de Concentração, uma delas era Musicologia, que era onde ficavam as dissertações de mestrado de música, e aos poucos esses programas foram... essas três áreas foram ganhando autonomia. (IAZZETTA, 2009)

Com o incremento e o desenvolvimento das pesquisas, o termo Musicologia parece não mais abarcar todo o repertório de dissertações e teses produzidas. O volume da produção cresce, não somente em música, mas também nas artes plásticas e artes cênicas e, paralelamente, também o corpo docente cresce em quantidade e apresenta-se significativamente mais qualificado. Este é o momento em que os departamentos começam a reivindicar às universidades estaduais paulistas a subdivisão dos Programas de Pós-Graduação em Artes em novos programas autônomos, a saber, música, artes plásticas e artes cênicas.

Então quando a gente apresentou essa proposta de subdivisão em três novos programas, a gente teve que realmente fazer uma justificativa muito grande para demonstrar que não havia sentido em manter os três programas juntos, porque já eram três estruturas autônomas, que já existia um corpo, uma massa crítica, um corpo docente, uma produção passada nas três áreas, individualmente, que justificava a separação. (IAZZETTA, 2009)

Na UNICAMP isso se deu em 2001, na UNESP, em setembro de 2002 e, na USP, em novembro de 2006:

E em 2006, mais ou menos, a gente entrou com o processo para a separação dos três cursos, das três áreas que se tornaram três cursos independentes, e a área de Musicologia passou então a se chamar Programa de Pós-Graduação em Música. A aprovação, se não me engano, é do início de 2007, é quando entra em funcionamento oficialmente, tanto na USP como na CAPES, o novo Programa de Música, que herda tanto os alunos como o corpo docente e uma parte da estrutura da antiga área de Musicologia do Programa de Artes e se torna um Programa independente. (IAZZETTA, 2009) 


\subsection{1 - Musicologia e Teoria Musical}

A citada mudança do paradigma quanto ao que poderia ser considerado conhecimento para as artes, e em especial para a música, justifica o que parece ter sido um caminho comum às universidades estaduais paulistas: que se aceite com naturalidade que os primeiros programas de pós-graduação em música nelas criados tenham apontado, quase sem exceção, para a introdução dos conceitos musicológicos.

Mas seguramente a linha mais predominante ali na UNESP foi a Musicologia. A linha de Performance não havia, e, se havia no papel, ela não havia na prática. Ela não acontecia. (KERR, 2009)

O estudo da musicologia, calcado em questões históricas, encaixa-se com bastante conforto ao modelo proposto pelo mundo acadêmico. Podem-se pesquisar as fontes, obter partituras e documentos e elaborar ou reelaborar uma descrição histórica a partir dos dados obtidos. Podem-se reconstruir biografias, o mundo musical de uma determinada região em determinada época e assim por diante.

Os estudos sobre a produção musical brasileira, sempre necessários devido à escassa documentação e precária organização em que se encontrava essa produção, foram terreno fértil para as pesquisas musicológicas. Tomemos, como exemplo, o estudo da Música Colonial Brasileira. Tido como assunto relevante a ser pesquisado, este campo não deixa dúvidas quanto à sua importância, visto que descobrir, recolher, catalogar, estudar, contextualizar e disponibilizar material que se refere à construção de uma identidade musical nacional sempre gozou de grande prestígio nos meios acadêmicos.

Portanto, a pós-graduação em música instala-se via pesquisa histórica, apoiandose nos pressupostos das pesquisas históricas que outras áreas já realizavam. O Prof. Dr. Fernando Iazzetta assim relembra esta fase:

... existia um grande número de pesquisas que a gente poderia chamar de Musicologia Histórica, especialmente de música brasileira. Isso foi sempre uma tendência grande no programa, que talvez tenha até diminuído um pouco nos últimos anos, mas anteriormente era. Alguns poucos trabalhos de 
análise, mais focada na análise instrumental, análise de obras ou de repertório específico, e alguns poucos trabalhos na área de Educação. Mas não dá para dizer, assim, que o Programa tivesse uma característica muito específica. Dá para dizer o tipo de trabalho que não costumava existir. Não costumavam existir trabalhos muito voltados para a prática, performance e composição, especialmente porque isso não fazia parte do perfil dos Programas de Pós-Graduação de Música em geral, os trabalhos de Educação eram poucos porque não existiam orientadores nessa área, então os trabalhos acabavam sempre dominantemente na área de História da Música, um pouco de análise misturada com história, e alguns trabalhos um pouco mais reflexivos: crítica, teoria, e tal. Esses eram um pouco menos numerosos. Hoje acho que já tem uma expansão maior, a área de Musicologia é dominante ainda, mas o corpo de professores cresceu muito e ele é diverso. Então já tem vários trabalhos na área de Práticas Interpretativas, alguns trabalhos, por exemplo, nas áreas que eu atuo, de música e tecnologia. (IAZZETTA, 2009)

A partir dos estudos musicológicos, de caráter mais histórico, uma outra tendência vai se fixando: o estudo teórico, analítico das obras musicais. Parte-se de conceitos de análise, abarcando áreas como o estudo das formas, da harmonia, do contraponto, dos sistemas (modal, tonal, atonal, etc.) e outros, de maneira a obter um "encaixe" teórico, a partir dos pressupostos do próprio material musical, com premissas analíticas já próprias da teoria musical. Aqui, ao lado das pesquisas que se apoiavam em questões históricas e que tinham como parâmetro a metodologia das pesquisas históricas já realizadas em outros programas, começam a surgir os trabalhos que têm a própria estrutura musical como objeto de estudo. O estudo histórico caminha lado a lado com o estudo da música a partir de sua gramática.

\subsection{2 - Educação Musical e Composição}

Em seguida, surgem as demandas que dizem respeito à teorização dos processos composicionais e da educação musical.

Esta última caracteriza-se como muito apta e apropriada, afim ao mundo acadêmico, pois que, aliando-se às pesquisas e metodologias já existentes na área da educação em geral, com elas estabelece rapidamente um amplo diálogo. A função da 
Educação é reconhecida unanimemente na sociedade, o que abre caminho para a aceitação, quase sem restrições, para que a Educação Musical ocupe seu espaço, mesmo que de início pensada apenas como complemento à educação formal, apêndice que complementa o quadro geral. Vejamos que a Educação Musical pode ser facilmente contextualizada no mundo acadêmico, valendo-se das teorias da educação desenvolvidas para outras áreas, utilizando-as ou pensando-as como modelos a serem reutilizados pela música. Os pressupostos do registro dessas pesquisas são os mesmos que já haviam sido aceitos desde sempre na academia: projetos escritos, teorias que têm por esteio nomes de grandes pensadores, trabalhos escritos e baseados em fontes também escritas, ou seja, a linguagem escrita e a cultura "dos livros" subsidiam a aceitação e legitimam a presença da educação musical no meio acadêmico.

A composição musical e os processos que a envolvem são também, aos poucos, abordados pelas pesquisas em música. Estando a composição musical registrada em partitura, vai possuir também os pressupostos que justificarão sua presença nos programas de pós-graduação em música. Temos aqui um documento ou registro (a partitura), temos fontes históricas que podem apontar para a contextualização em que as obras foram criadas (musicologia histórica), temos a possibilidade da análise da partitura (teoria musical), temos ainda a figura do próprio compositor a ser estudada (ainda musicologia histórica). Ou seja, as questões envolvidas na pesquisa que aborda a composição musical e seus processos conversam com as já aceitas questões musicológicas e teóricas, e a elas ainda se juntam outras. $\mathrm{O}$ estudo dos novos sistemas de composição, criados ou utilizados especialmente no século XX, baseiam-se em conceitos matemáticos, físicos e acústicos, cujos pressupostos atendem amplamente aos requisitos acadêmicos, podendo facilmente ser relacionados com as ciências exatas. Mesmo as questões que envolvem o estudo dos processos de criação musical, ainda que pouco explicados e explicáveis até hoje, estão baseados em áreas como cognição, psicologia e epistemologia, o que também lhes garante o status de pesquisas "científicas".

O que queremos demonstrar aqui é como a música, ao adentrar a universidade e confrontar-se com as questões que envolvem a produção e recepção de pesquisas, teve que adequar-se aos pressupostos de outras áreas. Uma vez no mundo acadêmico, as artes tiveram que reportar-se a uma estrutura já cristalizada, que premiava as áreas 
previamente estabelecidas. A pesquisa em música, sendo assim, foi tratada, pensada, criticada e julgada segundo parâmetros nascidos para outras áreas, que à música vão sendo adaptados, digamos.

\subsection{3 - Práticas Interpretativas}

Por outro lado, as pesquisas em Práticas Interpretativas ainda parecem carecer de uma orientação metodológica mais definitiva, se assim podemos dizer. Elas não se constroem prioritariamente sobre documentos preservados, ou sobre processos históricos, ou ainda sobre princípios das ciências exatas que orientem sistemas de composição, nem sobre questões relacionadas à educação musical. As fontes escritas que ilustram as Práticas Interpretativas são muito menos numerosas, o que as torna menos afeitas à abordagem tradicional da pesquisa. Segundo o Prof. Dr. Fernando Iazzetta, na USP:

... acho que o que faltaria de fato é você regular essa área de Práticas Interpretativas, porque aparentemente a estrutura do curso foi pensada para um curso voltado para a Musicologia, um curso voltado para questões teóricas, vamos dizer assim. (IAZZETTA, 2009)

As Práticas Interpretativas apóiam-se mais sobre o desempenho técnico dos músicos em seus instrumentos, sobre a maneira como esses conhecimentos se realizam e são assimilados pelo indivíduo e, ainda, na maneira específica como estes conhecimentos são transmitidos aos alunos (aulas "de instrumento"). O que isto significa? Que a maneira de realizar pesquisa em Práticas Interpretativas, embora possa aproveitar-se de formas utilizadas em outras áreas, principalmente as mais próximas, terá de construir sua própria metodologia e organizar suas premissas sob outros parâmetros. E, como nota a $\operatorname{Prof}^{a}$ Dr $^{a}$ Dorotéa Kerr, este é um trabalho contínuo e incansável a ser realizado:

Estabelecer o perfil, ter novas linhas, perceber a sociedade, perceber o que precisaria ter agora, que outras disciplinas oferecer, que outras linhas de pesquisa criar. Isto teria que estar em constante contato com isso, é um aprimoramento contínuo. (KERR, 2009) 
Não se trata, obviamente, de inventar do nada, já existem experiências em todos os ramos do saber humano, mas a consistência de pesquisas voltadas às Práticas Interpretativas está mais em jogo do que aquelas realizadas em áreas já mais cristalizadas, pelo menos em nosso país, áreas como a Musicologia e a Educação Musical. Ainda há que se tentar quais caminhos as Práticas Interpretativas poderiam tomar no seio acadêmico, visto que várias possibilidades parecem apresentar-se:

Você pode pensar que um conhecimento mais sofisticado na área de práticas interpretativas, que venha de uma atividade de pós-graduação, possa gerar, por exemplo, melhores professores de música, possa gerar um conhecimento maior do que é o papel da música na sociedade, possa gerar um conhecimento maior de questões históricas e estilísticas dentro da música. E que, obviamente, tudo isso, em alguma medida, vai reverter para a performance musical, mas não da maneira direta e imediatista ... (IAZZETTA, 2009)

Particularmente desafiadora é a necessidade de desenvolver-se uma maneira eficiente de se registrar uma atividade que é, por sua natureza, não afeita à linguagem verbal. Inúmeras vezes deparamo-nos com relatos de músicos que afirmam não poder argumentar do ponto de vista lógico-racional sobre as decisões que tomam acerca de suas interpretações, mas que garantem que há algo, pouco explicável, mas bastante discernível, que os guia e os ampara numa determinada direção. E que qualquer desvio dessa "direção de interpretação" é por eles notada e corrigida. Devido a isso, mesmo a transmissão deste conhecimento é tradicionalmente realizada de maneira oral, nas aulas "de instrumento", através de demonstrações ou sugestões por vezes permeadas de alusões e imagens poéticas, ainda que careçam de precisão. Por vezes, um gesto do professor transmite mais e melhor do que se ele tentar expressar-se por palavras.

\section{4 - Áreas de Concentração e Linhas de Pesquisa nos Programas de Pós- Graduação em Música das universidades estaduais paulistas.}

Podemos agora, diante do exposto, observar como estão hoje estruturados os Programas de Pós-Graduação em Música das universidades estaduais paulistas. 
Consultando a organização atual dos programas, constatamos a seguinte estrutura, quanto a áreas de concentração e respectivas linhas de pesquisa:

\section{Programa de Pós-Graduação em Música da USP}

Área de Concentração: Musicologia

Linha de Pesquisa: História, Estilo e Recepção

Área de Concentração: Processos de Criação Musical

Linha de Pesquisa: Técnicas Composicionais e Questões Interpretativas

(USP, 2009)

\section{Programa de Pós-Graduação em Música da UNESP:}

Área de Concentração: Interpretação/Teoria e Composição

Linhas de Pesquisa: Epistemologia e Práxis do Processo Criativo

Área de Concentração: Musicologia/Etnomusicologia/Educação Musical

Linhas de Pesquisa: Abordagens Históricas, Estéticas e Educacionais do Processo de Criação; Transmissão e Recepção da Linguagem Musical

(UNESP, 2009)

\section{Programa de Pós-Graduação em Música da UNICAMP:}

Área de Concentração: Fundamentos Teóricos

Linhas de Pesquisa:

- Musicologia histórica e etnomusicologia

- Linguagem: percepção, estruturação e análise musical

- Interfaces tecnológicas para os processos musicais e acústicos 
Área de Concentração: Práticas Interpretativas

Linhas de Pesquisa:

- Processos interpretativos nos diferentes estilos e períodos musicais

- Técnica e pedagogia dos instrumentos musicais

\section{Área de Concentração: Processos Criativos}

Linhas de Pesquisa:

- Suportes instrumentais e materiais para composição e improvisação

- Análise aplicada de técnicas e processos composicionais

(UNICAMP, 2009)

Pelos esquemas acima, constata-se, pois, que as pesquisas em Práticas Interpretativas constam dos programas de Pós-Graduação, variando, no entanto, quanto ao modo de sua inserção nesses programas.

Assim, enquanto na UNICAMP já ocupa espaço como Área de Concentração específica, com linhas de pesquisa determinadas, na USP aparece nomeada como "Questões Interpretativas", fazendo parte da Linha de Pesquisa da Área de Concentração "Processos de Criação Musical". No programa da UNESP, os trabalhos que envolvem Práticas Interpretativas encontram acolhida na Área de Concentração "Interpretação/Teoria e Composição", que apresenta como Linhas de Pesquisa "Epistemologia e Práxis do Processo Criativo".

E, na UNICAMP, parece-nos que o fato de Práticas Interpretativas constituírem já uma Área de Concentração manifesta o maior espaço a elas concedido.

A área de Práticas Interpretativas é muito forte na UNICAMP, sempre foi. A preocupação nossa sempre foi de equacionar essa produção artística ao pensar e à sistematização, à reflexão sobre essa produção. Agora, sem dúvida, a [área de] Práticas Interpretativas, seja ela enquanto Área de Concentração, como ela é hoje, mas seja ela como produto também de outras Áreas de Concentração, ela é muito forte. É uma coisa, é uma característica emblemática da nossa pós-graduação, essa preocupação com 
a produção artística, ou a práxis interpretativa vinculada a essa reflexão. (KAYAMA, 2009)

Do ponto de vista geral, entretanto, as constatações apontam para uma especialidade ainda em processo de se consolidar no âmbito da pesquisa acadêmica. Esse fato, porém, não impede que trabalhos em Práticas Interpretativas sejam realizados e contribuam justamente para esse processo de consolidação. Prova-o a amostragem que apresentamos como cerne de nossa pesquisa, corroborada pelas impressões dos três docentes entrevistados:

Eu acho que o programa vem apurando ou depurando a sua estrutura, o seu oferecimento de disciplinas, os próprios projetos que são desenvolvidos dentro do programa. Eu percebo assim que o nosso processo seletivo está muito mais eficiente, está muito mais objetivo, mais claro e mais eficiente na sua aplicação. (KAYAMA, 2009)

Então, vamos dizer, já existe a área, a maneira como a divisão é feita me parece adequada, mas ela não contempla as particularidades da área de Práticas Interpretativas como ela deveria contemplar. (IAZZETTA, 2009)

... os Programas de Pós-Graduação no Brasil, em Artes, em Música, eles são novos, mas já trouxeram benefícios. Você vê já um volume grande de produção, embora possamos fazer todas as críticas. (KERR, 2009)

... nesse momento, existe uma mudança grande, talvez até um rigor maior nos projetos, na seleção dos projetos dos alunos que entram [no programa de pós-graduação], na qualidade desses projetos; e também, por parte dos professores, um esforço maior de ter uma produção acadêmica mais consistente, o que tem acontecido gradualmente. (IAZZETTA, 2009)

A questão das Práticas Interpretativas sempre levantou polêmicas, como veremos no segundo capítulo. Daí decorre a diversidade na forma como é tratada e inserida nos Programas. Contudo, embora Práticas Interpretativas seja o enfoque de nosso trabalho, não podemos deixar de considerar, a partir da pesquisa que realizamos, que outras especialidades também enfrentam o mesmo problema quanto à sua inserção 
nos Programas, ainda que com menor intensidade. A explicação está no fato de ser recente a implantação dos cursos de Pós-Graduação em Música em nosso país e no Estado de São Paulo, conforme ficou exposto acima. A necessidade de adequação dos programas às reais condições de cada universidade também é outro fator a se levar em conta. Considere-se, como exemplo significativo, que áreas de concentração e linhas de pesquisa somente podem se estabelecer a partir da realidade do corpo docente de que dispõe a universidade. 


\section{CAPÍtULO 2}

Neste capítulo, serão abordados artigos que tratam de assuntos pertinentes ao tema Pesquisa em Práticas Interpretativas. Tais artigos têm sua relevância no contexto de nosso trabalho, por tratarem de questões diretamente implicadas com os desafios que tais pesquisas enfrentam no meio acadêmico.

Os artigos pesquisados são:

Título: Pesquisa em Práticas Interpretativas: situação atual

Autor: Marcelo Gerschfeld

Fonte: Anais do IX Encontro Anual da ANPPOM

Rio de Janeiro - 1996

Título: Entre a Arte e a Ciência: reflexões sobre a Pesquisa em Performance Musical

Autor: Fausto Borém

Fonte: Anais do I SNPPM

Belo Horizonte - 2000

Título: Pesquisa e Performance

Autora:Sonia Albano de Lima

Fonte: Anais do XIII Encontro Anual da ANPPOM

Belo Horizonte - 2001

Título: Práticas Interpretativas e a Pesquisa em Música: dilemas e propostas

Autor: Felipe Avellar de Aquino

Fonte: Revista Opus, nº 9 - Revista Eletrônica da ANPPOM 2003

Título: Pesquisa no Brasil: Balanço e Perspectivas

Autora:Lúcia Barrenechea

Fonte: Revista Opus, $\mathrm{n}^{\circ} 9$ - Revista Eletrônica da ANPPOM 2003 
Notaremos em nossa exposição que, embora alguns temas apareçam apenas em um dos artigos, vários temas são comuns a eles. Esta coincidência de ocorrências indica, portanto, que tais temas são realmente relevantes e merecem análise atenciosa.

\section{1 - O registro da prática}

A pesquisa em Práticas Interpretativas sempre suscitou discussões. Desde o início das pesquisas nesta subárea, questões foram levantadas sobre suas peculiaridades e sua metodologia. Tudo parece originar-se no fato de que se trata de notar ou anotar processos que, historicamente, são tratados de maneira essencialmente prática, ou "nãoteórica".

Sendo os intérpretes os autores privilegiados de tais estudos, é de se esperar que a obtenção de habilidades para o registro de suas práticas não se dê de maneira imediata, especialmente nos casos em que toda a formação e a atuação profissional destes músicos não apontaram, desde sempre, nesta direção.

Músicos instrumentistas, acostumados com o palco e seus desafios, grande parte deles também experientes professores em seus instrumentos, viram-se, quando no ambiente acadêmico, diante da necessidade de produzir textos, artigos e colocar no papel o fruto de suas pesquisas. Textos estes que espelhassem um trabalho que para eles era, antes de tudo, algo prático, do dia-a-dia, conhecimento cuja absorção e transmissão tradicionalmente eram realizadas por via oral ou por processos imitativos (referimo-nos, aqui, a aulas de instrumento nas quais o professor toca simultaneamente com o aluno de maneira que, com o mínimo auxílio de palavras, o aluno é capaz de apreender as idéias musicais postas em jogo).

Na maioria dos cursos de graduação em música os alunos de instrumentos ainda recebem uma formação essencialmente baseada na transmissão verbal de conhecimentos, muitas vezes demonstrados pelo professor através da execução; tal como aprendeu na infância, o aluno universitário tende a imitar o seu professor e a aceitar tudo passivamente, sem uma elaboração reflexiva daquilo que lhe está sendo mostrado ou ensinado. E, quando não imita o professor, procura imitar aquilo que ouve em gravações, sem muita crítica do que ouve. (GERSCHFELD, 1996, p. 61) 
Obviamente, não se trata de afirmar que os instrumentistas sejam incapazes de realizar a tarefa de escrever sobre sua prática, mas antes de perceber que, na maior parte das vezes, não foram treinados para isso ou não sentem a necessidade de fazê-lo. E não por acaso. O domínio da técnica dos instrumentos e o desenvolvimento da interpretação musical são, como sabemos, tarefas árduas e longas, que demandam perseverança e determinação. Esperar que, simultaneamente a isso, o músico já desenvolvesse uma atenção para o registro teórico deste processo seria pedir que ele somasse a suas qualidades artísticas um viés pedagógico e uma visão de pesquisa. Na maior parte das vezes, o tempo que seria exigido por tais reflexões é empregado no próprio estudo do instrumento. E este fato, em nossa ótica, não é algo reprovável a priori, deixemos claro.

Sobre isso, vejamos a opinião de Sonia Albano de Lima:

Até hoje, a maioria dos performances (sic) não sentiu a importância de relatar através da linguagem escrita, aquilo que fazem com os seus instrumentos, com a voz ou com os processos de criação. O fazer musical ainda é visto na sociedade atual como trabalho artesanal que não produz conhecimento, mesmo exigindo do instrumentista uma atividade mental que, algumas vezes, se manifesta de forma desordenada. (LIMA, 2001, p. 532)

E o mesmo tema aparece citado por Fausto Borém:

"Um dos problemas mais graves no ensino da performance musical é a tradição dos professores de instrumento, canto e regência de não documentarem suas reflexões sobre a experiência de fazer e ensinar música. No mundo da música de concerto, grandes instrumentistas, cantores e maestros permanecem apenas como uma memória inacessível às gerações posteriores que não tiveram a oportunidade de ouvi-los enquanto eram ativos como intérpretes e professores.” (BORÉM, 2001, p. 143)

Além disso, é preciso admitir que não se trata de tarefa simples o exercício de procurar descrever processos interpretativos, de natureza multidisciplinar, em linguagem acadêmica. A música e o fazer musical criaram seu próprio repertório de gestos e leituras, muitas vezes "intraduzíveis" para o vernáculo. Em casos extremos, a 
redução que se operaria poderia até mesmo justificar a negativa a este processo. Sonia Albano assim se manifestou sobre essa questão:

A tradução dos fenômenos musicais utilizando a linguagem discursiva é um procedimento extremamente complexo, pois envolve uma lógica diversa. Se aplicada à performance musical, essa metalinguagem assume proporções ainda maiores, pois é na praxis musical que se encontra o objetivo principal da pesquisa performática. (LIMA, 2001, p. 536-537)

Mas, se por um lado podemos perceber a dificuldade de transposição das experiências pedagógicas e interpretativas para um formato de pesquisa acadêmica, de registro formal, por outro notamos que há também certa desconfiança prévia dos intérpretes quanto à possibilidade de uma tradução eficiente. Esta situação não pode, entretanto, amparar justificativas no sentido de não se tentar realizar essa transposição, visto que é necessário esgotar as possibilidades antes de negá-las, ainda mais em se tratando de uma subárea que deseja afirmar-se. E se esta dificuldade transforma-se em resistência, outras questões podem estar em jogo, como nos mostra Fausto Borém:

Outra dificuldade da pesquisa em performance decorre da resistência dos próprios instrumentistas, cantores e maestros que não crêem numa fundamentação teórica da interpretação, da técnica instrumental, da reconstrução dos estilos de época no fazer musical. Esta postura pode esconder, muitas vezes, uma resistência do performer musical frente a um salto qualitativo - seja através da documentação do conhecimento que produz, seja na reflexão periódica de suas abordagens pedagógicas - que lhe é exigido na sua adaptação ao meio acadêmico. (BORÉM, 2001, p. 144)

Entretanto, ao adentrar o ambiente acadêmico, o instrumentista, agora professor universitário, depara-se com as exigências inerentes ao cargo. O tripé docênciapesquisa-extensão cobra deste instrumentista que ele amplie sua área de atuação. Esta realidade se impõe no momento em que a Música adentra a universidade, tornando-se mais perceptível ainda quando os cursos de pós-graduação em música são criados. Ao obter o status de curso universitário, as artes, e mais especificamente a música, por ser uma arte não verbal, terão que adequar-se aos padrões teóricos que orientam as pesquisas em outras áreas. 
E, sendo a música uma espécie de caçula neste processo, acaba por herdar os modelos que as áreas pioneiras fundaram e moldaram ao longo do tempo. Se os pressupostos destas outras áreas não se aplicam à música, é tarefa dela demonstrá-lo e, mais do que isso, propor modelos que lhe sejam pertinentes.

\section{2 - Registro e reconhecimento acadêmico}

O surgimento de um vocabulário e metodologia próprios da pesquisa em Práticas Interpretativas tem sido um processo com percalços e dificuldades constantes. A polêmica em torno do assunto é marcante em todos os autores que se dispõem a enfrentá-lo e questioná-lo, como se depreende claramente dos artigos aqui citados e comentados.

Em se tratando de Educação Musical, Musicologia e mesmo Composição, há pressupostos teóricos interdisciplinares que falam a favor da utilização de ferramentas já presentes. A Educação Musical tem, como ponto de partida, as teorias da educação em geral, já bastante desenvolvidas nas universidades e possuidoras de volumosa e consagrada bibliografia. A Musicologia claramente comunga diversos pressupostos metodológicos com a História, enquanto a Composição é, ela mesma, já um exercício "posto em papel”, afim ao registro teórico, portanto.

Já a subárea de Práticas Interpretativas, segundo os argumentos que expusemos nos parágrafos anteriores, não possui um histórico de registro consolidado ou uma área claramente afim que os possua.

Some-se a esse quadro uma certa resistência que os próprios instrumentistas podem vir a manifestar em produzir registros criteriosos sobre suas práticas. Se, como argumentamos, os instrumentistas tiveram uma formação voltada principalmente para o estudo do instrumento e, mesmo em sua atuação como professores, privilegiaram formas orais e imitativas de transmissão de conhecimentos, é natural que procurem perpetuar essa maneira de atuar mesmo quando professores em universidades.

... existe por parte de um grande número de intérpretes uma grande resistência à pesquisa e à produção de documentos escritos. Provavelmente, essa resistência reflete uma postura definida quanto ao papel e ao significado da performance musical, pois uma parcela significativa dos executantes tem a firme convicção de que fazer música como produto final 
é mais do que suficiente, sendo desnecessário falar, refletir ou escrever sobre o fazer musical. (GERSCHFELD, 1996, p. 61)

Talvez julgando que o registro não seja necessário, ou que isso seja tarefa para um musicólogo e não para um instrumentista, estes agora professores universitários tendem, em alguns casos, a não aceitar sem ressalvas a tarefa de produzir trabalhos teóricos que espelhem e reverberem seus valiosos conhecimentos. Mas, como já dissemos, este parece ser um pressuposto que acompanha a introdução da Música nos cursos universitários e especialmente de pós-graduação.

E se esta postura realmente está presente nos professores instrumentistas, acaba por estender-se aos alunos de pós-graduação ou graduação, também instrumentistas que geralmente atuam como professores, não necessariamente em instituições de ensino superior. Daí ocorrerem distorções quando da elaboração de projetos que visam à obtenção de bolsas de apoio a pesquisas, como nos relata Marcelo Gerschfeld, ao analisar as pesquisas na área de Práticas Interpretativas (embora extensa, consideramos extremamente relevante a citação):

Como membro do Comitê Consultor de Letras e Artes da FAPERGS, como consultor ad hoc do CNPq e da CAPES, e tendo sido membro do Comitê Assessor da CAPES e coordenador do curso de pós-graduação em Música da UFRGS, tive e continuo tendo, nos últimos anos, a oportunidade de examinar diversos projetos de pesquisa na área de práticas interpretativas, assim como pedidos de bolsa para o exterior em nível de mestrado e de doutorado, tanto de professores e alunos de pós-graduação como também de instrumentistas independentes. Verificava-se até pouco tempo atrás, na grande maioria dos casos, um grande desconhecimento dos procedimentos metodológicos de um projeto de pesquisa e de alguns conceitos básicos como: o objeto de estudo, a aplicação prática dos resultados, o interesse institucional e comunitário, ou o retorno social do investimento. Tinha-se a impressão, muitas vezes, que o projeto de um documento escrito era percebido como um "mal necessário para conseguir a bolsa"; além disso, um exame mais atento sugeria que o principal interesse desses candidatos era estudar o seu instrumento com algum grande e renomado professor, e aquilo que deveria ser apenas uma solicitação de bolsa para um curso de especialização no instrumento ficava camuflado na forma de um projeto de 
mestrado ou até mesmo de doutorado. Exemplos disso eram pedidos de bolsa para o Exterior feitos por candidatos que escolhiam universidades que não exigiam documento formal escrito, ou então que propunham projetos do tipo "Análise da obra para piano de ..." (compositor brasileiro ativo e atuante profissionalmente, que vive no Brasil onde se encontram todas as suas obras), que poderiam perfeitamente ser desenvolvidos aqui mesmo. Apesar de que algumas mudanças nesse quadro já ocorreram, [...] muitos dos aspectos acima ainda persistem. (GERSCHFELD, 1996, p. 60)

Por fim, percebamos que os critérios para o julgamento do rendimento docente, as avaliações de produtividade e mesmo os mecanismos para obtenção de verbas em pesquisas e apoio a projetos são baseados nos modelos criados para cursos com perfil não similar ao de Música. Então, a citada resistência em registrar de maneira "científica" (ou pelo menos sob normas aceitas pelo meio acadêmico) os processos das Práticas Interpretativas apenas retarda o crescimento da subárea ou, pior, reforça possíveis preconceitos que porventura ainda pairem sobre o papel e a presença das artes e mais especificamente da Música nas universidades.

A própria progressão funcional do docente muitas vezes passa pela obtenção de graus de excelência cuja verificação e comprovação se dão pela confecção de trabalhos teóricos. E se a citada resistência à documentação da produção interpretativa é vencida apenas para obter a qualificação exigida, não se caminha senão de maneira tortuosa em direção à solução:

Assim, essa situação de área emergente, como também a implantação de sistemas de avaliação e de progressão na carreira docente que valorizam precipuamente a produção intelectual científica, ocasionou algumas distorções em relação à função do músico no cenário universitário. Desencadeou-se, no início, uma espécie de compulsão generalizada à pesquisa e à produção de material escrito, intimidando e assustando os intérpretes, que se viram na obrigação de se tornarem verdadeiros “musicólogos”, sob pena de não serem reconhecidos pelos seus pares e pelo sistema. Surgiram, então, trabalhos que pouco ou nada tinham a ver com pesquisa sistemática e a conseqüente produção de conhecimento. Mais do que isso, em muitos casos transparecia a simples necessidade de "produzir", 
visando o cumprimento de exigências para alcançar a pontuação necessária para obter a progressão funcional. (GERSCHFELD, 1996, p. 62)

Mesmo o apoio dos órgãos de fomento à pesquisa parece estar ligado à questão de que áreas nas quais se reconhece claramente uma produção intelectual já gozam de prestígio unânime, enquanto as áreas artísticas, quando não produzem material (escrito) que possa ser julgado segundo padrões científicos, tendem a encontrar resistência para seus pressupostos e a valoração de suas realizações. Portanto, a falta de metodologia como apontada acima por Gerschfeld estaria a influenciar a análise dos projetos de pesquisa na subárea de Práticas Interpretativas, bem como os resultados a que estas pesquisas chegariam não seriam também devidamente validados e consolidados, o que contribuiria para retardar o crescimento da subárea. Isto foi assim descrito por Sonia Albano de Lima:

A pesquisa científica que envolve a performance, de natureza altamente interdisciplinar, na maioria das vezes, pelo fato de não seguir uma normatização metodológica bem traçada, vem atuando desordenadamente na elaboração de conhecimentos musicais, provocando reflexos desastrosos na avaliação e fiscalização de sua produção. (LIMA, 2001, p. 531)

Portanto, podemos concluir que um maior reconhecimento da subárea de Práticas Interpretativas que se reflita na análise dos projetos de pesquisa e de seus resultados pelos órgãos de fomento passa, necessariamente, pela definição de uma metodologia mais precisa, pelo menos em seus princípios gerais. Se esta demanda for atendida, muito provavelmente os pressupostos "científicos" estariam sendo claramente satisfeitos, mesmo que adaptados à realidade das Práticas Interpretativas, e isso ainda tenderia a oferecer um modelo básico, sempre sujeito a ampliações e alterações, mas razoavelmente uniforme, de organização do objeto de estudo.

Atualmente, a performance musical defronta-se com a necessidade de definir e caracterizar a metodologia empregada na elaboração de sua produção científica, a fim de que seus resultados sejam melhor avaliados pelos órgãos de fomento à pesquisa. Outros campos de pesquisa musical, a exemplo da musicologia e educação musical, portadores de metodologias mais definidas, têm obtido maior reconhecimento da comunidade científica, 
mesmo que incorporando em sua produção fontes e material da área de práticas interpretativas. (LIMA, 2001, p. 531)

Soma-se a este quadro ainda o fato de que, nos setores de análise encarregados da avaliação dos projetos ligados às artes, à música e às Práticas Interpretativas, os avaliadores em muitos casos possuem formação em outras áreas, artísticas ou não, o que dificulta a compreensão dos pressupostos de trabalhos sobre interpretação musical, dadas as suas peculiaridades. Significa isso que, junto à possível deficiência metodológica dos projetos e da falta de reconhecimento da subárea, atua também, na outra ponta, uma possibilidade de imprecisão no julgamento do mérito dos projetos apresentados. Este problema foi assim comentado por Sonia Albano de Lima:

Outro motivo prejudicial reside na escassez de assessores especializados em performance musical, fato que emperra a maioria dos projetos encaminhados aos setores de análise, uma vez que eles são julgados e fiscalizados, em boa parte, por especialistas de outras áreas artísticas, quando não, de áreas ligadas às ciências físicas e, até mesmo, sociais. (LIMA, 2001, p. 531)

\section{3 - O status do instrumentista}

Todo o exposto acima pode ainda estar ligado a questões anteriores, mais profundas, questões que tratam do status do instrumentista, com as implicações históricas que lhe dizem respeito.

A música era tida como uma "ciência" pelos antigos (gregos), e assim se manteve durante séculos. Lembremos que, na divisão das disciplinas contidas nas artes liberais (septem artes liberales), a música estava inscrita no quadrivium, ao lado da aritmética, da astronomia e da geometria; ou seja, a música era uma "ciência dos números". No trivium estavam a gramática, a retórica e a dialética, ou seja, as disciplinas mais afeitas à palavra e, portanto, menos precisas quanto à possibilidade de serem comparadas quantitativamente. Atualmente, dizemos: "área de exatas" e "área de humanas". A música estaria, se mantida a concepção dos antigos gregos, entre as "exatas". Curiosamente, hoje, o senso comum enxerga-a sem maiores questionamentos na "área de humanas". Além disso, trata-se de atividade artística, na qual, muito mais do 
que números e proporções, são privilegiadas as percepções e sensações, ligadas ao campo emotivo e sensível. Ou seja, a música perdeu seu caráter "científico" e este fato parece ter contribuído para sua tardia aceitação na universidade. Fausto Borém notou com clareza este ponto, vejamos:

De objeto preciso e definido por meio de fórmulas, a música metamorfoseou-se nesse objeto pouco palpável, quase etéreo, que o senso comum moderno consagrou, e cuja compreensão tornou-se privilégio dos "sensíveis". De fato, não causa estranhamento dizer que a música, atualmente, está muito mais para Arte do que para Ciência. De filha legítima da matemática, a música passou a filha adotiva da emoção. (BORÉM, 2001, p. 142)

E também a posição do instrumentista foi durante séculos vista como inferior à dos compositores que, por sua vez, eram inferiores aos teóricos, aqueles que verdadeiramente conheciam a essência da música (vale dizer, suas relações numéricas, “científicas”). E talvez estas questões ainda estejam presentes na avaliação do trabalho dos professores instrumentistas hoje nas universidades. Amparemos nossa afirmação com a seguinte citação de Borém:

Na Baixa Idade-Média, no Cap. 34 do seu De institutione musica (Os fundamentos da música), Boethius elegeu os músicos teóricos como a classe superior e inteligente, secundados pelos compositores, a quem chamou de classe média, provida de algum conhecimento e discernimento. Finalmente, destinou aos intérpretes (instrumentistas e cantores) a classe inferior, caracterizada pela ignorância e pouco alcance intelectual. (BORÉM, 2001, p. 142)

Com efeito, mesmo que hoje notemos que tais posicionamentos não possam mais ser sustentados, havemos de citar certo preconceito histórico que pairou sobre a atividade musical, e que afetou também o status do músico instrumentista. Vista como atividade acessória, não essencial, não fundamental, a prática artística e musical normalmente não goza do prestígio de outras profissões "mais nobres".

Confirma tal afirmação o fato de grandes compositores e instrumentistas terem obtido prestígio mais facilmente em situações nas quais lhes foi atribuída a qualidade de 
gênios. O virtuosismo, especialmente a partir do século XIX, colocou em evidência a figura do intérprete, mas, talvez mesmo entre os músicos, tendeu-se a manter o pressuposto de que o trabalho intelectual e elaborado ficaria a cargo dos compositores e teóricos da música, enquanto os instrumentistas seriam uma espécie de repetidores, hábeis em algo que em si mesmo não seria digno de grandeza.

Esses pressupostos encontram eco na maneira como o próprio homem construiu seus conhecimentos, especialmente na maneira ocidental de abordar e valorizar o conhecimento que prioriza o aspecto racional em detrimento de vários outros, tais como o intuitivo.

O problema vem de longa data e incide, principalmente, na forma como o homem ocidental pensa a música. Ele não só, separa o pensar do fazer música, como também, desqualifica a prática musical como atividade capaz de produzir conhecimentos. (LIMA, 2001, p. 531)

Portanto, o desenvolvimento de habilidades motoras extremamente finas, de percepção auditiva focada e corretiva, do sentido preciso e estrito de ritmo e andamento, de contornos timbrísticos e mesmo de adequações estilísticas, escolhidos judiciosamente, embora sejam todos aspectos fundamentais e essenciais para a construção de um bom instrumentista, tenderam a não ser vistos nem valorizados como essenciais, porque a razão encontrava dificuldade em explicá-los como valiosos, pois não se adequavam facilmente ao padrão de conhecimento racional, parâmetro insubstituível até algum tempo atrás.

Tais pressupostos interferem, de alguma maneira, no papel que o professor instrumentista desempenha na universidade. Sua presença no meio acadêmico pode ser vista com desconfiança, o mesmo acontecendo em relação à música. Daí a não se dar valor às pesquisas baseadas nas Práticas Interpretativas seria apenas um pequeno salto. Sobre essa questão, assim se pronunciou Sonia Albano de Lima:

A pesquisa científica, utilizando um plano de ação sistemático e ordenado, tem como finalidade, a produção de conhecimentos em todas as áreas, inclusive na performance, uma vez que essa forma ordenada de agir, permite-lhe atuar nos mais variados campos do saber. É inegável que tanto a ciência como as artes contribuem sistematicamente para a formação do 
conhecimento humano, mesmo que as metodologias para a produção do conhecimento de uma e outra se processem de forma diversa. (LIMA, 2001, p. 532)

Talvez mesmo entre os músicos houvesse uma certa cisão, ficando de um lado os compositores e musicólogos, ligados à teoria e aos processos analíticos, que grafam no papel suas idéias, perfis reconhecíveis quanto às suas qualidades racionais e intelectuais, enquanto de outro estariam os instrumentistas, "músicos práticos", que ocupariam seu tempo dominando funções menores, pertencentes ao domínio das atividades motoras, trabalho repetitivo e pouco elaborado.

E se, ao adentrar a universidade, sob este velado preconceito, os instrumentistas ainda manifestarem certa resistência em documentar suas pesquisas na subárea de Práticas Interpretativas, e demonstrarem pouco conhecimento sobre metodologia na confecção de projetos nos diversos níveis, estarão ratificando as impressões daqueles que assim não os reconhecerão como pares, e oferecendo os argumentos necessários para reiterar os preconceitos.

Mas o estudo que culmina com a interpretação de uma obra musical ao instrumento, em nível de excelência, é na verdade também preciosa elaboração intelectual, que exige a intervenção de vários talentos, nem todos racionais, mas que precisam ser coordenados com vistas a um resultado geral equilibrado e satisfatório. Não se trata de repetir, mas de interpretar. Não é apenas "tocar um instrumento", mas sim construir uma idéia musical completa, de sentido (musical) claro.

... é necessário dar-se conta que interpretar uma obra musical através de um instrumento é na verdade o resultado de um processo extremamente complexo, de natureza interdisciplinar, que inclui múltiplas etapas e que portanto embute em si mesmo uma intensa e extensa atividade de pesquisa. A decodificação de um texto musical em todos os seus níveis e o preparo técnico para a execução abrangem a tomada de uma série de decisões que são o resultado de profunda elaboração intelectual. Assim, escolher dedilhados adequados, o tipo de sonoridade, a projeção do som na sala de concerto, a compreensão da estrutura da obra e das idéias do compositor, a questão do estilo, a análise técnica da execução, a experimentação de novos timbres e efeitos dinâmicos, entre inúmeras outras variáveis, nada mais são do que exemplos dessa intensa atividade intelectual. Todo bom intérprete 
transita ao natural por esses campos como parte integrante de sua atividade profissional. É, portanto, e pela sua própria natureza, um pesquisador, pois para chegar aos resultados pretendidos, deve trabalhar de maneira séria e organizada. No entanto, os caminhos percorridos para chegar a esses resultados raramente são documentados, e como a transmissão desse conhecimento se dá geralmente de maneira verbal ou pela execução em si, quase nunca pode ser utilizado por outros intérpretes como referência ou ponto de partida para gerar novos conhecimentos. (GERSCHFELD, 1996, p. 62-63)

$\mathrm{E}$ as informações que concorrem para a construção de uma idéia musical coerente podem ser também de ordem racional. Um estudo sobre como eram construídos os instrumentos em outra época e como soariam então pode oferecer informações importantes sobre como era a sonoridade que seu compositor esperava ouvir e, portanto, indicar como devemos abordar determinada obra em instrumentos modernos. Estudos sobre a biografia do compositor, cartas e relatos de época podem indicar, por exemplo, que determinada obra foi escrita como resposta a uma feroz crítica, alterando profundamente a maneira de tocá-la (por exemplo, se uma ironia está contida).

A performance musical é uma atividade extremamente complexa, que envolve aspectos psicológicos, fisiológicos, pedagógicos, estéticos, históricos, técnicos, mecânicos, neurológicos, sociológicos, enfim, há uma gama de indagações que dizem respeito ao fazer musical e suas interfaces. Essa variedade de áreas de assuntos que se interrelacionam com as práticas interpretativas exige metodologias e sistematizações específicas, e isso é o que faz com que a pesquisa nessa área seja tão complexa e rica. (BARRENECHEA, 2003, p. 114)

Levando-se em conta o conceito de "inteligências múltiplas", introduzido por Howard Gardner, as quais fazem parte de nossas habilidades, tende-se, hoje, a considerar que o desenvolvimento delas é mais importante do que apenas o aspecto racional, embora este não seja descartado em hipótese alguma. Se antes apenas a ciência era vista como possuidora de um modelo de estudo, de pesquisas e de experiências, capazes de gerar conhecimentos e resultados verificáveis, palpáveis, hoje considera-se 
que a arte possui paradigmas complementares aos científicos, que abarcam outras áreas do saber humano, e que têm sido descritas inclusive em termos científicos. (GARDNER, 1994)

E Sonia Albano de Lima constata, referindo-se ao pensamento do início do século XX:

... assistimos no início do século XX à implantação de um novo modelo de conhecimento, onde a construção do saber se processa de forma dinâmica, interrelacionada e sistêmica. [...] O novo paradigma epistemológico trata arte e ciência como formas complementares de obtenção de conhecimento, regidas por um cérebro composto de dois hemisférios, o direito e o esquerdo, que interagem continuadamente. Ainda que o hemisfério esquerdo tenha uma atividade preponderantemente racional, analítica e seqüencial e o hemisfério direito, tenha uma atividade mais intuitiva, as duas funções cerebrais não agem isoladamente. Sob esse argumento, não se justifica que o conhecimento obtido pela arte sofra tratamento diferenciado daquele obtido pela ciência. (LIMA, 2001, p. 533-534)

Já não é possível, hoje, ignorar que não há uma divisão tão clara do trabalho, não estão os "músicos teóricos" tão afastados dos "músicos práticos", eles se comunicam todo o tempo, e se enriquecem com este intercâmbio, a tal ponto que esta divisão entre "teóricos" e "práticos" já não faz mais qualquer sentido (se é que em algum momento o fez).

Os conhecimentos que compositores e intérpretes devem possuir hoje para serem reconhecidos como capacitados são praticamente os mesmos, mas provavelmente adquiridos em ordens inversas. Os intérpretes tendem a adquirir primeiramente os pressupostos mecânicos e motores, para com o tempo mergulharem na linguagem musical em busca da maneira de interpretá-los. O papel da intuição na interpretação, embora preservado, não pode mais substituir a aquisição de conhecimentos históricos, tais como as questões de estilo, além de diversos outros. Por outro lado, compositores não podem mais ignorar, por exemplo, as novas possibilidades a que os instrumentos foram alçados, por força da invenção e virtuosidade de seus mais importantes intérpretes. 


\section{4 - Iniciativas e publicações}

Podemos constatar, no entanto, que todas essas dificuldades apresentadas, que envolvem a pesquisa em Práticas Interpretativas, desencadearam o surgimento de iniciativas que estão contribuindo para a consolidação da área de Música e, conseqüentemente, da subárea em questão nos meios acadêmicos.

A Associação Nacional de Pesquisa e Pós-Graduação em Música - ANPPOM, criada em abril de 1988, realiza encontros anuais, reunindo docentes e pesquisadores de todas as subáreas de Música. Promove o entrosamento entre os cursos de pós-graduação do país e o intercâmbio com pesquisadores estrangeiros. Fomenta a geração do conhecimento e o rigor científico na atividade de pesquisa. Uma das contribuições da ANPPOM é a revista "OPUS", em versão impressa e online, criada em 1989, e que publica artigos científicos e resenhas nas diversas áreas do conhecimento musical, em português, espanhol e inglês. (ANPPOM, 2009)

PER MUSI - Revista Acadêmica de Música - é uma publicação gratuita do Programa de Pós-Graduação em Música da Universidade Federal de Minas Gerais (UFMG). Criada em 2000, por Fausto Borém, docente da mesma universidade, nasceu voltada à peformance musical e, em 2004, passou a privilegiar toda a área de música. Publica artigos científicos em português, inglês e espanhol e até mesmo partituras, resenhas e entrevistas relativas à pesquisa em música. (UFMG, 2009)

EM PAUTA é a revista do Programa de Pós-Graduação em Música da Universidade Federal do Rio Grande do Sul (UFRGS), voltada à produção e publicação de conhecimento científico em Música, tais como artigos inéditos, trabalhos empíricos e ensaios. (UFRGS, 2009)

Vinculado ainda ao Programa de Pós-Graduação em Música da Universidade Federal do Rio Grande do Sul, encontramos uma das mais promissoras iniciativas no âmbito específico das Práticas Interpretativas. Trata-se do GPPI - Grupo de Pesquisa em Práticas Interpretativas, coordenado pela $\operatorname{Prof}^{\mathrm{a}} \operatorname{Dr}^{\mathrm{a}}$ Cristina Capparelli Gerling, que consolida um espaço para estudos e pesquisas nessa subárea, promovendo a legitimidade da execução musical no meio acadêmico como um campo de 
conhecimento a ser aprofundado pelo debate, pela reflexão e por trabalhos de cunho científico. Congrega artistas/pesquisadores, docentes e discentes do Programa de PósGraduação em Música das três universidades federais do Estado, além de docentes de outras instituições do Brasil e do exterior. (UFRGS, 2009)

Constata-se, portanto, que, se a trajetória da Música rumo a seu adentramento na Universidade fez-se de percalços por ter que adequar-se aos padrões já instituídos em outras áreas do conhecimento, foram estas mesmas dificuldades, tomadas como desafios, que desencadearam formas de organização e ação capazes de já apresentarem resultados significativos. A prova está justamente no fato de que a pesquisa em Práticas Interpretativas, a subárea da Música em que mais se afiguravam os problemas e dificuldades, já consegue reverter esse quadro. Cresce o número de cursos de pósgraduação, de seminários, simpósios e publicações a ela dedicados. 


\section{CAPÍtULO 3}

Levando em consideração, como exposto no capítulo anterior, que as maiores dificuldades no trabalho de pesquisa em Música concentram-se na subárea de Práticas Interpretativas, mas que, ao mesmo tempo, o quadro já começa a reverter-se, passamos a fazer um levantamento dessa realidade.

Assim, neste capítulo, teremos uma análise e comentários sobre a abordagem das Práticas Interpretativas em pesquisas realizadas, recentemente, em nível de Mestrado e Doutorado, nas universidades estaduais paulistas.

Foram escolhidos nove trabalhos, dos quais três dissertações de Mestrado apresentadas ao Departamento de Música da Universidade de São Paulo (USP), três dissertações de Mestrado apresentadas à Universidade Estadual Paulista (UNESP), e uma tese de Doutorado e duas dissertações de Mestrado apresentadas à Universidade Estadual de Campinas (UNICAMP), abarcando o período de 2002 a 2007.

O método de escolha destes nove trabalhos foi assim conduzido: primeiramente, foi definido que as Universidades Estaduais Paulistas seriam as pesquisadas, pois que nos interessava estabelecer o estado destes trabalhos em instituições públicas. Em seguida, foi delimitado o período em que estas pesquisas se deram. Como lidamos com uma subárea recente, o período abarcado (2002 a 2007) coincide com o momento no qual a subárea vai ocupando gradativamente mais espaço nos Programas de PósGraduação em Música. Visto ter nossa pesquisa se iniciado em 2008, delimitamos os seis anos anteriores como o período a ser pesquisado, o que garante a atualidade dos trabalhos aqui analisados.

Três dissertações e/ou teses foram escolhidas de cada universidade para prover o equilíbrio entre as instituições contempladas. Após pesquisar as dissertações e teses, observando cuidadosamente seus resumos, introduções, conclusões e sumários, as escolhas recaíram sobre aquelas que tratavam diretamente do assunto presente em nossa pesquisa, o que, na maioria, mas não na totalidade das vezes, apareceu impresso já no título do próprio trabalho. Apenas um dos selecionados não contempla no próprio título o assunto, mas apresenta, em seu desenvolvimento, aspectos relevantes sobre interpretação da obra que tematiza. Trata-se de "As miniaturas musicais de Nilson Lombardi”, apresentado à UNESP por Juliano Brito Kerber, em 2007. 
Uma abordagem mais estatística, que mapeasse todos os trabalhos, seria de grande valia, mas consideramos que eleger uma amostragem desse quadro e procurar desvendar perfis recorrentes poderia apontar caminhos para futuras pesquisas.

Cumpre notar ainda que tais trabalhos buscam abordar as questões interpretativas sempre numa obra específica ou em segmentos determinados da obra de um compositor (como por exemplo: Estudos para Piano de Almeida Prado, os 12 Estudos para Violão de Francisco Mignone, entre outros), o que pode nos mostrar mais claramente como se procura estabelecer, em nossos cursos de pós-graduação, o vínculo entre prática instrumental e a pesquisa que a desvenda, enriquece e registra. 


\section{1 - Análises dos trabalhos selecionados}

Neste item, cada trabalho é apresentado através de um quadro contendo os dados que o identificam e da reprodução de seu sumário. A seguir, são levantados os aspectos relevantes quanto ao objeto de estudo, metodologia empregada e resultados obtidos.

\subsection{1 - Universidade de São Paulo - USP}

3.1.1.1 - O Salmo 150 de Ernst Mahle - questões composicionais e interpretativas Identificação da Dissertação:

\begin{tabular}{|l|l|}
\hline Título & $\begin{array}{l}\text { O Salmo 150 de Ernst Mahle - questões composicionais e } \\
\text { interpretativas }\end{array}$ \\
\hline Autor & Cíntia Maria Annichino Pinotti \\
\hline Nível & Mestrado \\
\hline Ano da defesa & 2002 \\
\hline Orientador & Prof. Dr. Marco Antonio da Silva Ramos \\
\hline
\end{tabular}

Apresentação do sumário da dissertação:

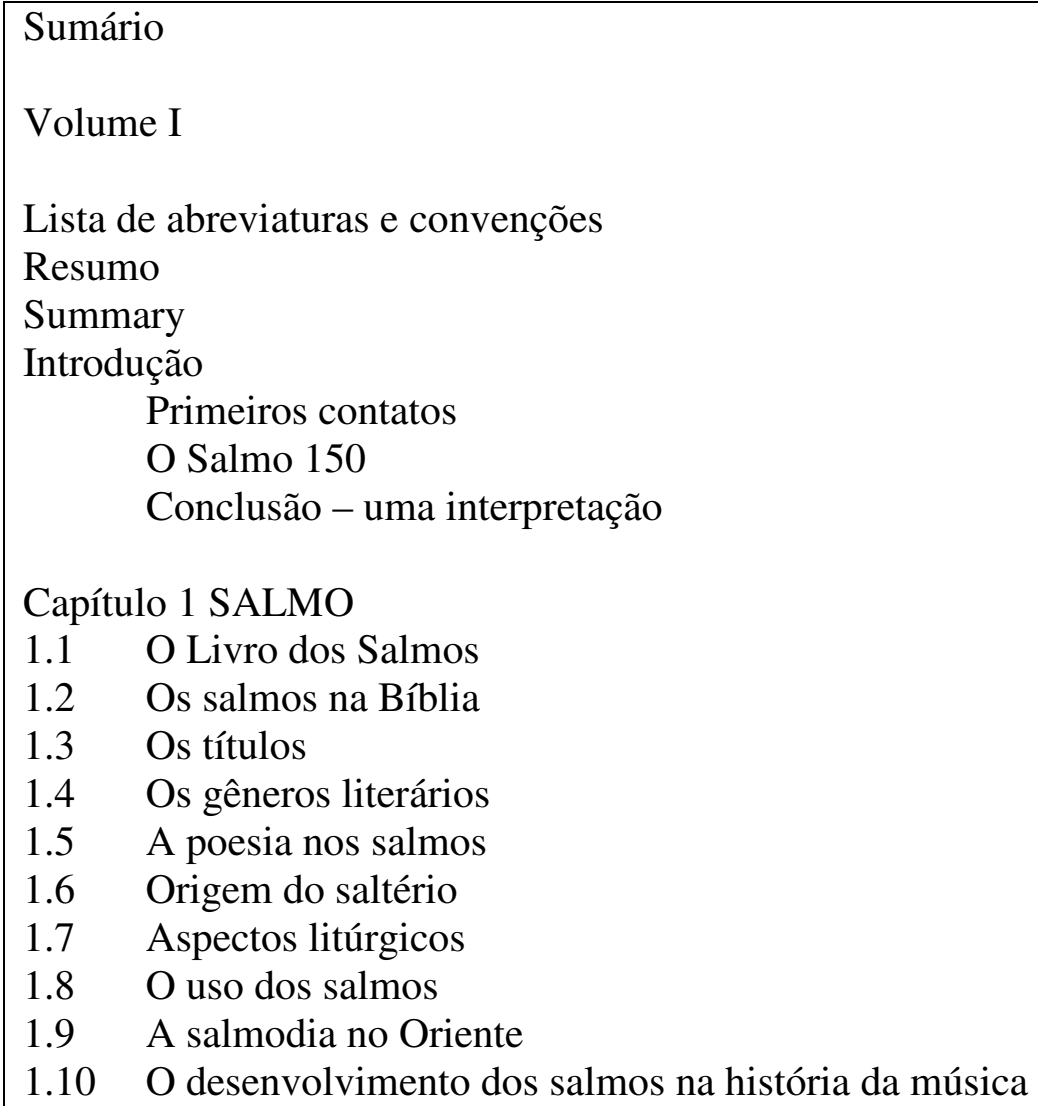


Capítulo 2 SALMO 150 - ERNST MAHLE

2.1 O compositor

2.2 Sua obra

$2.3 \quad$ O didata

2.4 Obra sacra

2.5 O salmo 150

2.6 As seções

2.6.1 Primeira seção $(a)$ - Allegro Moderato

2.6.2 Segunda seção $(b)$ - a piacere/Vivo 2.6.2.1 Relação texto/música

2.6.3 Terceira seção $\left(a^{\prime}\right)$ - Allegro Moderato

2.6.3.1 Variações entre os Allegro Moderato ( $a$ e $a^{\prime}$ )

Capítulo 3 OUTROS SALMOS 150

3.1 Outros salmos 150

3.2 Breves comentários sobre as obras

3.2.1 Anton Bruckner e o Psalm 150

3.2.2 Charles Ives e o Psalm 150

3.2.3 Brasílio Itiberê e o Salmo 150

3.2.4 Ernst Widmer e o Salmo 150

3.2.5 Robert Walker e o Psalm 150

3.2.6 Ernani Aguiar e o Psalm 150

3.3 Tabela dos Movimentos

3.4 Tessituras vocais

3.5 Utilização do texto e partes corais/orquestrais

3.5.1 Comparações

3.5.2 Preferência do compositor

3.6 Tabela comparativa

Conclusão

Bibliografia

Volume II

Apêndices:

Partitura analisada do Salmo 150 de Ernst Mahle - $3^{\mathrm{a}}$ versão

Partitura do Salmo 150 de Ernst Mahle com considerações de interpretação

Anexos:

Partitura do Salmo 150 de Ernst Mahle $-1^{\mathrm{a}}$ versão

Partitura do Salmo 150 de Ernst Mahle - $2^{\text {a }}$ versão

Partitura do Salmo 150 de Ernst Mahle - $3^{\text {a }}$ versão

Partitura do Salmo 150 de Ernst Mahle - $4^{\text {a }}$ versão

Redução para piano do Salmo 150 de Ernst Mahle

Partitura do Psalm 150 de Anton Bruckner

Partitura do Psalm 150 de Charles Ives 
Partitura do Salmo 150 de Brasílio Itiberê

Partitura do Salmo 150 de Ernst Widmer

Partitura do Salmo 150 de Robert Walker

Partitura do Salmo 150 de Ernani Aguiar

Texto original em hebraico do Salmo 150

Tradução da "Bíblia de Jerusalém" do Salmo 150

Catálogo das obras de Ernst Mahle

\section{Considerações sobre a dissertação:}

Esta dissertação apresenta-se claramente com uma forma de trabalho que parte do geral para o particular, como podemos constatar através do sumário.

O primeiro capítulo fornece subsídios didáticos para o entendimento dos salmos em vários aspectos, como sua origem e caráter bíblico-religioso, sua utilização litúrgica, o desenvolvimento dos salmos na história da música.

O segundo capítulo focaliza brevemente o compositor e sua obra de forma geral, para logo em seguida tratar de suas obras sacras, e, somente então, particularizar especificamente o Salmo 150 de Ernst Mahle, objeto do estudo. Mesmo nesse nível de particularização, não se exime de partir de algo mais geral, a saber, das quatro versões da obra, para então eleger a terceira versão - coral-sinfônica com texto em português para ser analisada. Sobre a análise assim nos diz Pinotti na Introdução ao trabalho: "Fizemos a análise do Salmo 150, mostrando sua forma, instrumentação (2.6), suas seções (2.6), utilização modal e harmônica (2.6), as relações texto/música (2.6) e a capacidade descritiva do compositor." (PINOTTI, 2002, p. 2)

Após o segundo capítulo ter considerado pormenorizadamente o Salmo 150 de Ernst Mahle, na versão coral-sinfônica com texto em português, o terceiro capítulo dedica-se a considerar outras obras escritas sobre o Salmo 150, com breves comentários sobre cada compositor e montando tabela comparativa relativa a alguns aspectos presentes nas mesmas: tessituras vocais, andamentos, utilização do texto, preferências de cada compositor na utilização do texto. Justifica o procedimento com as seguintes palavras: "Espera-se que esta abordagem do Salmo 150 de Mahle e dos seis compositores mencionados, possa despertar o interesse de outros, dada a sua amplitude". (PINOTTI, 2002, p. 3) 
$\mathrm{Na}$ conclusão a autora descreve sua própria interpretação da obra. Entre vários aspectos descritos, propôs uma metronomização de cada andamento, já que:

Os andamentos não receberam indicações metronômicas do compositor. Há apenas as denominações das seções - Allegro Moderato, a piacere/ Vivo, Allegro Moderato.

Esta prática é comum em Mahle. Para ele a velocidade tem que ser considerada levando-se em conta vários fatores - local de execução, número de assistentes, clima do ambiente, tipo do conjunto que executa a peça, entre outros - e esses fatores são variáveis a cada execução. (PINOTTI, 2002, p. 100)

Para ilustrar o trabalho e demonstrar suas intenções e escolhas, Pinotti resolveu levar a cabo uma execução da obra. Segundo a autora relata, foi realizado um concerto com o Coral Misto e a Orquestra Sinfônica Jovem da Escola de Música de Piracicaba “Maestro Ernst Mahle”, abrindo a Defesa da Dissertação. É ela quem afirma: “... o real fechamento deste trabalho se dará no momento do concerto, trazendo à tona as Questões Interpretativas, linha de pesquisa onde se insere meu orientador e por conseguinte meu próprio trabalho.” (PINOTTI, 2002, p. 3)

3.1.1.2 - Radamés Gnattali: "Suíte para Quinteto de Sopros" - Estudo Analítico e Interpretativo

Identificação da dissertação:

\begin{tabular}{|l|l|}
\hline Título & $\begin{array}{l}\text { Radamés Gnattali: “Suíte para Quinteto de Sopros” - Estudo } \\
\text { Analítico e Interpretativo }\end{array}$ \\
\hline Autor & Jamil Mamedio Bark \\
\hline Nível & Mestrado \\
\hline Ano da defesa & 2007 \\
\hline Orientador & Prof. Dr. Rogério Luiz Moraes Costa \\
\hline
\end{tabular}

\section{Apresentação do sumário da dissertação:}

Sumário

Introdução 
Parte I: Radamés Gnattali: Dados Biográficos

1. Formação musical

2. Carreira no rádio

3. Compositor, regente e arranjador

4. Referências

Parte II: Suíte para Quinteto de Sopros

1. Considerações sobre a forma Suíte

1.1. Prelúdio

1.2. Valsa

1.3. Modinha

1.4. Choro

2. A formação Quinteto de Sopros

3. Análise

3.1. $1^{\circ}$ Movimento - Prelúdio

3.1.1. Análise

3.1.2. Sugestões para Interpretação

3.2. $2^{\circ}$ Movimento - Valsa

3.2.1. Análise

3.2.2. Sugestões para Interpretação

3.3. $3^{\circ}$ Movimento - Modinha

3.3.1. Análise

3.3.2. Sugestões para Interpretação

3.4. $4^{\circ}$ Movimento

3.4.1. Análise

3.4.2. Sugestões para Interpretação

3.5. $5^{\circ}$ Movimento

3.5.1. Análise

3.5.2. Sugestões para Interpretação

Conclusão

Bibliografia

Anexos

1. Partitura da Suíte para Quinteto de Sopros de Radamés Gnattali

2. CD contendo a gravação da Suíte para Quinteto de Sopros de Radamés Gnattali 


\section{Considerações sobre a dissertação:}

Uma possível motivação pessoal de Bark na escolha dessa obra de Gnattali para sua pesquisa reside no fato de ele, também instrumentista, já ter vivenciado sua execução e interpretação, como se pode verificar nos anexos ao trabalho: "CD contendo a gravação da Suíte para Quinteto de Sopros de Radamés Gnattali”, executada por um grupo musical do qual o próprio Bark faz parte.

O trabalho inicia-se com o levantamento de dados biográficos de Radamés Gnattali, contextualizando-o historicamente no cenário da música erudita brasileira, na intenção de investigar possíveis influências e tendências estilísticas no processo de sua composição.

Em seguida, faz-se uma exposição sobre a forma Suíte, a forma musical do objeto estudado, traçando o processo de seu surgimento e evolução, culminando com a especificação dos movimentos utilizados na composição da Suíte para Quinteto de Sopros.

No terceiro capítulo, Bark analisa cada um desses movimentos: Prelúdio, Valsa, Modinha, Choro e Final. Para isso, utiliza-se dos fundamentos teóricos de Schoenberg, Berry e Zamacois, como nos informa na introdução da dissertação, visando estabelecer pressupostos analíticos para identificar a linguagem e os elementos composicionais característicos da obra. A análise de cada movimento é seguida de sugestões de interpretação.

Observemos dois trechos dessas sugestões, relativos ao Prelúdio:

Flauta, oboé, clarinete e fagote iniciam o primeiro movimento com um ataque em intensidade $f$. Como apresenta caráter ritmado e enérgico é imprescindível que seja absolutamente simultâneo. Ainda nesses dois compassos iniciais, a articulação deve ser staccato. Estes primeiros compassos servem de preparação para a entrada da trompa no compasso 3. (BARK, 2007, p. 46)

No primeiro movimento é importante ressaltar que os instrumentos que executam notas longas devem conservar dinâmica sempre inferior aos 
instrumentos que apresentam linhas melódicas. O andamento deve ser mantido durante o decorrer do movimento, por isso a insistência da importância de manter um direcionamento, principalmente em situações onde os músicos tendem a atrasar, como em figuras sincopadas e diminuendos. (BARK, 2007, p. 48)

Na conclusão, afirma Bark:

Este estudo sistemático orienta e sugere opções para uma interpretação mais consciente, promovendo uma relação íntima entre a obra e os executantes e, como conseqüência favorece uma maior compreensão por parte do ouvinte. (BARK, 2007, p. 117)

\subsubsection{3 - Missa Ferial de Osvaldo Lacerda - Uma Análise Interpretativa}

\section{Identificação da dissertação:}

\begin{tabular}{|l|l|}
\hline Título & $\begin{array}{l}\text { Missa Ferial de Osvaldo Lacerda - Uma Análise } \\
\text { Interpretativa }\end{array}$ \\
\hline Autor & Angélica Giovanini Micheletti Lessa \\
\hline Nível & Mestrado \\
\hline Ano da defesa & 2007 \\
\hline Orientador & Prof. Dr. Marco Antonio da Silva Ramos \\
\hline
\end{tabular}

\section{Apresentação do sumário da dissertação:}

Sumário:

Introdução

Capítulo 1 - Os aspectos freqüenciais: melodia, contraponto e harmonia na Missa Ferial

$1.1 \quad$ Kyrie

1.2 Sanctus

1.3 Benedictus

1.3.1 Fugato

1.3.2 Alegre

1.4 Agnus Dei 
Capítulo 2 - Os Aspectos relativos ao timbre e às intensidades

$\begin{array}{ll}2.1 & \text { Kyrie } \\ 2.2 & \text { Sanctus } \\ 2.3 & \text { Benedictus } \\ & 2.3 .1 \quad \text { Fugato } \\ & 2.3 .2 \quad \text { Alegre } \\ 2.4 & \text { Agnus Dei }\end{array}$

Capítulo 3 - Figurações rítmicas na Missa Ferial

3.1 Da Utilização das Constâncias Rítmicas

3.2 As Figurações Rítmicas nas Construções Temáticas

3.2.1 Kyrie

3.2.2 Sanctus

3.2.3 Benedictus

3.2.3.1 Fugato

3.2.3.2 Alegre

3.2.4 Agnus Dei

3.3 Da Utilização das Figurações Rítmicas na Missa Ferial

Capítulo 4 - A Missa como um Todo: Apontamentos para uma possível performance

Conclusão

Bibliografia

Apêndice

Anexo

\section{Considerações sobre a dissertação:}

A partir do sumário, percebe-se nesta dissertação um caráter bastante objetivo, numa estrutura de capítulos, itens e subitens logicamente organizados, visando explícita e diretamente à análise.

Tal procedimento, no entanto, não se furta em traçar, na Introdução, um perfil biográfico do compositor, através do qual desvendam-se as circunstâncias históricas em que a obra foi composta, momento desencadeado pelo Concílio Ecumênico Vaticano II, que propôs a aculturação da liturgia, aí incluindo-se a música sacra. A obra de que trata o trabalho é justamente a primeira das quatro missas escritas por Osvaldo Lacerda para responder a essa proposta, agregando elementos da cultura brasileira à música sacra católica. 
Cada um dos três primeiros capítulos trata, respectivamente, de determinados aspectos musicais das várias partes da Missa: aspectos frequienciais (melodia, contraponto e harmonia) no primeiro capítulo; aspectos relativos ao timbre e à intensidade, no segundo; e figurações rítmicas, no terceiro.

Quanto aos parâmetros orientadores da análise, informa Lessa:

O estudo de cada um desses elementos que formam a obra foi desenvolvido a partir do referencial de análise de Marco Antonio da Silva Ramos, da utilização de bibliografia específica sobre análise musical, e do estudo sobre documentação referente à música sacra depois do Concílio Vaticano II, principalmente os documentos da Comissão Nacional de Música Sacra. Tem-se, ainda, como referência de estudo da obra, a entrevista inédita realizada com o compositor - encontra-se como apêndice deste trabalho. Para melhor compreensão das constâncias rítmicas da música brasileira, buscou-se a coleta de dados a partir de dados de pesquisa realizada por Villa-Lobos. (LESSA, 2007, resumo)

No quarto capítulo, segundo a própria autora, aborda-se:

... a construção da obra como um todo. Isso se dá a partir da reflexão sobre as conclusões de cada aspecto anteriormente estudado, através de apontamentos que sugerem uma leitura interpretativa para uma possível performance. (LESSA, 2007, p. 15)

A partir da análise dos três primeiros capítulos, no quarto capítulo são revelados elementos unificadores rítmicos e melódicos da composição e as ambiências que se estabelecem através dos recursos utilizados, ambiências em sintonia com a semântica litúrgica e, no aspecto musical, ambiências modais.

De posse de todos os elementos levantados, a autora oferece, neste quarto capítulo, apontamentos para uma possível interpretação, dos quais transcrevemos o seguinte exemplo:

O Agnus Dei poderia ser interpretado como o retorno à calma e ao caráter apresentado na primeira parte da missa até o compasso 17 com anacruse. A partir deste, ainda que não indicada, poder-se-ia iniciar um stringendo que 
teria a volta in tempo do compasso 21 com direcionamento para a cadência final da obra, respeitando a indicação de andamento do compositor. Esta liberdade de alteração de andamento estaria ligada ao procedimento de repetição intensa das células melódicas e rítmicas e à função deste trecho, já que estes compassos representam de forma macro-estrutural o início da coda de toda a missa. (LESSA, 2007, p. 131)

A Conclusão fecha o trabalho, considerando atingidos os objetivos propostos.

\subsection{2 - Universidade Estadual Paulista - UNESP}

3.1.2.1 - Os fundamentos da interpretação musical: aplicabilidade nos 12 Estudos para Violão de Francisco Mignone

Identificação da dissertação:

\begin{tabular}{|l|l|}
\hline Título & $\begin{array}{l}\text { Os fundamentos da interpretação musical: aplicabilidade nos 12 } \\
\text { Estudos para Violão de Francisco Mignone }\end{array}$ \\
\hline Autor & Flávio Apro \\
\hline Nível & Mestrado \\
\hline Ano da defesa & 2004 \\
\hline Orientador & Prof. Dr. Giácomo Bartoloni \\
\hline
\end{tabular}

\section{Apresentação do sumário da dissertação:}

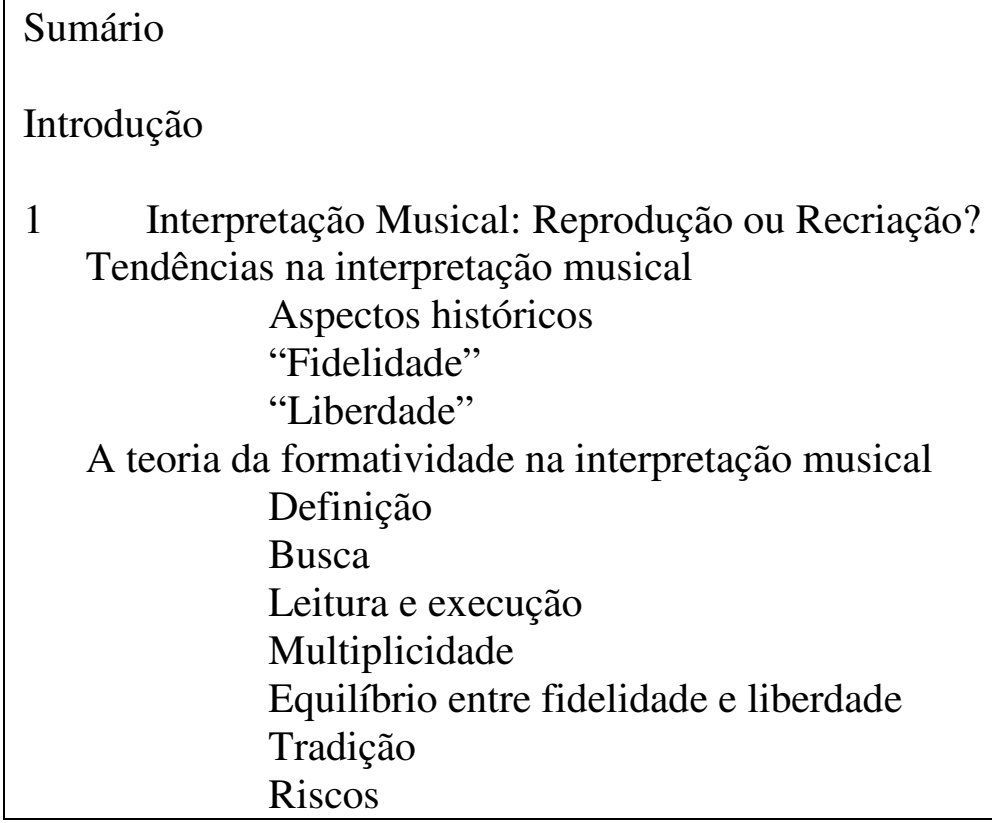

A teoria da formatividade na interpretação musical

Definição

Busca

Leitura e execução

Multiplicidade

Equilíbrio entre fidelidade e liberdade

Tradição

Riscos 


\begin{tabular}{|c|}
\hline Os limites da interpretação \\
Aplicação da Conceituação Teórica nos 12 Estudos para Violão de Francisco \\
Mignone \\
$2.1 \quad$ Os 12 Estudos para Violão \\
Introduzindo o objeto de estudo \\
Revisão bibliográfica \\
A produção violonística do compositor na década de 70 \\
Características gerais \\
Comentários sobre as versões \\
Aspectos Técnicos \\
Harmônicos duplos e triplos \\
Utilização dos cinco dedos da mão direita \\
Aberturas de mão esquerda \\
Notas repetidas na mesma corda \\
Ligados entre duas cordas \\
Arpejos apoiados \\
Glissandos reposicionadores \\
Pestanas irregulares \\
Efeitos timbrístico/imitativos \\
Propostas para Interpretação \\
2.2.3. \\
Considerações Finais \\
Bibliografia Básica \\
Referências Bibliográficas
\end{tabular}

\section{Considerações sobre a dissertação:}

Como relata a Introdução, o presente trabalho teve uma origem de cunho pessoal. O autor, intérprete violonista, sofreu, em sua formação, os efeitos de orientações contrastantes quanto à linha a imprimir à interpretação: fidelidade ao texto musical ou liberdade para recriá-lo. É ele quem nos diz:

Todos esses questionamentos giravam em torno de nossa própria trajetória musical e propuseram um método de investigação: a Hermenêutica. Por razões metodológicas, não trabalhamos com hipóteses a priori. Decidimos, assim, estabelecer enquanto objetivo dessa pesquisa a proposta de uma nova experiência de abordagem interpretativa aos Estudos de Mignone por 
meio da discussão e síntese das principais tendências histórico-filosóficas da interpretação. (APRO, 2004, p.11)

Nosso escopo foi meramente uma tentativa de resolvermos um conflito pessoal em relação à interpretação musical, o que nos levou a recorrer a outros níveis de conhecimento (História e Filosofia) para solucionar questões que não estavam sendo satisfatoriamente respondidas em nossa área. (APRO, 2004, p.19)

Uma vez que os textos teóricos específicos da área musical, relativos à interpretação, não lhe deram respostas suficientes, por oferecerem apenas fórmulas acabadas, Apro buscou na Teoria da Formatividade de Luigi Pareyson e nos conceitos de Lingüística de Umberto Eco amparo para uma abordagem interdisciplinar aplicável à proposta para uma leitura dos 12 Estudos de Mignone.

Como preparação para essa abordagem, traça antes um histórico das tendências da interpretação, cujo panorama inicial se divide em duas correntes: conservadora (prende-se à fidelidade à intenção do compositor) e relativista (prioriza a emoção do executante). Percorre todas as nuances em que se desdobram tais correntes antagônicas.

Na Teoria da Formatividade de Pareyson os aspectos de fidelidade e liberdade não se opõem, mas são complementares e dependem tão somente das possibilidades que um texto contém, o que vai ser o ponto de apoio de todas as propostas de interpretação que Apro traça em relação à obra escolhida - 12 Estudos de Mignone. Tal apoio vem também das formulações de Umberto Eco relativas aos limites da interpretação textual, baseadas em critérios de economia e pertinência. Tais parâmetros teóricos permitem a Apro elaborar propostas de leitura e interpretação que busquem o equilíbrio entre o respeito ao texto e ao compositor, sem tolhimento de sua personalidade de intérprete/pesquisador.

Com tal intento, são feitas colocações sobre o compositor e sua produção violonística, em cujo contexto se inclui um levantamento bibliográfico sobre Mignone, inclusive de todas as versões dos 12 Estudos. Ainda com esse intuito, são abordadas as características gerais dos 12 Estudos de Mignone e tecidos comentários sobre cada versão dos mesmos.

Entre as versões, encontra-se a versão do próprio pesquisador, denominada FA (Flávio Apro), sobre a qual ele mesmo afirma: 
A versão FA que propomos nesta pesquisa é uma tentativa de se obter uma execução mais próxima possível do autógrafo. Evitamos as facilitações e efetuamos as alterações de forma criteriosa, a fim de preservar ao máximo a profusão de detalhes harmônicos, melódicos ou polifônicos. (APRO, 2004, p. 78)

Seguem-se então aspectos técnicos de caráter didático, com sugestões de execução para dificuldades específicas de determinadas passagens violonísticas. Citamos aqui um trecho sobre glissandos reposicionadores, como exemplo:

O Estudo $N^{o} 4$ de Mignone apresenta uma dificuldade técnica específica: os saltos da região aguda para a grave são enormes e em posições extremas de cordas (da $1^{\text {a }}$ para a $6^{\mathrm{a}}$ ), dificultando a execução precisa. Sugerimos o uso do glissando como dedo guia a fim de favorecer o reposicionamento da mão esquerda ao ponto exato entre o final e o reinício de cada seqüência. (APRO, 2004, p. 89)

O trabalho culmina com propostas para interpretação de cada um dos estudos, sobre as quais já diz a Introdução:

A pesquisa encerra-se com uma análise de caráter hermenêutico de cada um dos estudos, indicando traços nacionalistas, influências de obras de outros compositores, bem como explanações a respeito dos subtítulos. (APRO, 2004, p. 13)

Extraímos dessas propostas o seguinte trecho, que finaliza as considerações sobre o Estudo $N^{o} 3$ :

Esse estudo, portanto, apesar de seu poliestilismo (que aponta para uma direção típica da pós-modernidade), apresenta uma coesão sonora que mais uma vez revela o talento do compositor em unir elementos díspares. Caberia, ao intérprete, desse modo, uma execução que privilegiasse o aspecto improvisatório, por meio de licenças de fraseado e liberdade agógica. Esta sugestão (e outras que faremos adiante) de interpretação mais 
livre deve ser tomada de maneira cautelosa, em vista do preconceito mútuo entre a "técnica aprimorada" do músico erudito e o "swing" do popular. (APRO, 2004, p. 97)

Apro não propõe hipóteses a priori, parte de dois questionamentos:

- A execução da música erudita brasileira, em seu aspecto interpretativo, deve ser mais gingada e criativa, conforme os preceitos de execução da música popular?

- Qual seria a abordagem interpretativa ideal para os 12 Estudos de Mignone? Uma execução que privilegie mais a fidelidade ao texto ou a liberdade do executante? (APRO, 2004, p. 10)

Toda a argumentação desenvolvida, elementos elencados e propostas práticas demonstram um trabalho de pesquisa teórica que não se afasta da prática interpretativa. Pelo contrário, parte dela e a ela retorna, permitindo que se afirme nas Considerações Finais:

Destacamos o fato de que o equilíbrio entre reprodução e recriação não é tarefa fácil de se atingir. $\mathrm{O}$ aspecto empírico parece ser fundamental nesse processo, pois a dosagem correta é decorrente de uma vivência acumulada, o que torna natural a expressão balanceada entre as duas tendências. (APRO, 2004, p. 113)

Nossa aplicação da união entre fidelidade e liberdade nos Estudos de Mignone buscou manter a essência e a unidade de cada peça, sem o aniquilamento de nossa própria personalidade. (APRO, 2004, p. 113)

Justifica-se, portanto, sua afirmação logo no início da Introdução:

Grande parte dos instrumentistas que se deparam com a perspectiva de enfrentar uma pós-graduação costumam lamentar o fato de ter de abandonar seus instrumentos [...] Tal fato não aconteceu conosco, pois exploramos esse território sem prejuízo recíproco. (APRO, 2004, p. 9) 
3.1.2.2 - Análise rítmico-prosódica como ferramenta para a performance da canção: um estudo sobre as canções de câmara de Claudio Santoro e Vinícius de Moraes

Identificação da dissertação:

\begin{tabular}{|l|l|}
\hline Título & $\begin{array}{l}\text { Análise rítmico-prosódica como ferramenta para a } \\
\text { performance da canção: um estudo sobre as canções de } \\
\text { câmara de Claudio Santoro e Vinícius de Moraes }\end{array}$ \\
\hline Autor & Wladimir Farto Contesini de Mattos \\
\hline Nível & Mestrado \\
\hline Ano da defesa & 2006 \\
\hline Orientador & Prof ${ }^{\text {a }}$ Dr $^{\text {a }}$ Martha Herr \\
\hline
\end{tabular}

Apresentação do sumário da dissertação:

Sumário

Introdução

Capítulo 1 Prosódia e canção: conceitos, contextos e discussões

1.1 Noções de prosódia

1.1.1 Prosódia, teoria literária e normas de pronúncia

1.1.2 Prosódia na lingüística moderna

1.1.3 Prosódia na música

1.1.4 Um panorama atual

1.2 Canção: objeto verbal e musical

1.2.1 Um conceito amplo de canção

1.2.2 Algumas questões metodológicas

Capítulo 2 Um modelo de análise rítmico-prosódica da canção

2.1 Considerações gerais

2.1.1 Contribuições dos modelos referenciais

2.1.2 Procedimentos analíticos propostos

$2.2 \quad$ Fase preliminar da análise

2.2.1 Delimitação de sintagmas melódicos na canção

2.2.2 Consideração das fontes referenciais

2.3 Aplicação dos procedimentos centrais

2.3.1 Fase 1: Estruturação

$1^{\text {a }}$ Etapa: Escansão Acentual de Componentes

$2^{\text {a }}$ Etapa: Discriminação de Agrupamentos Perceptíveis

2.3.2 Fase 2: Periodicidade

$3^{\text {a }}$ Etapa: Determinação de Domínios de Agrupamentos 


\begin{tabular}{|c|c|}
\hline & $4^{\text {a }}$ Etapa: Detecção de Níveis Hierárquicos \\
\hline 2.4 & Fase complementar da análise \\
\hline & 2.4.1 Níveis de hierarquia prosódica na canção \\
\hline & 2.4.2 Estabelecimento de linhas de interpretação \\
\hline & 2.4.3 Critérios e procedimentos \\
\hline & 2.4.4 Representação gráfica e espacial \\
\hline Capítulo 3 & Análise rítmico-prosódica da canção, na prática \\
\hline 3.1 & As canções de câmara de Claudio Santoro e Vinícius de Moraes \\
\hline 3.2 & Análise rítmico-prosódica das canções selecionadas \\
\hline & Análise 01. A mais dolorosa das histórias \\
\hline & Análise 02 . Acalanto da rosa \\
\hline & Análise 03. Alma perdida \\
\hline & Análise 04. Amor em lágrimas \\
\hline & Análise 05. Amor que partiu \\
\hline & Análise 06. Balada da flor da terra \\
\hline & Análise 07 . Bem pior que a morte \\
\hline & Análise 08. Cantiga do ausente \\
\hline & Análise 09. Em algum lugar \\
\hline & Análise 10. Jardim noturno \\
\hline & Análise 11. Luar do meu bem \\
\hline & Análise 12. Ouve o silêncio \\
\hline & Análise 13. Pregão da saudade \\
\hline Conclusão & \\
\hline Bibliografia & \\
\hline Fonografia & \\
\hline Volume 2 & \\
\hline Apêndice - & ases teóricas da análise \\
\hline Anexo - Ca & ões analisadas (poemas e partituras) \\
\hline
\end{tabular}

\section{Considerações sobre a dissertação:}

O sumário deste trabalho (como vemos acima) mostra-nos claramente uma forma de organização e metodologia coerente com sua proposta. Mattos dispensa as habituais considerações sobre biografia de compositores, autores e aspectos históricos, atendo-se apenas aos aspectos intrínsecos da obra analisada. Elege dentre os pressupostos teóricos oriundos da Lingüística e da Teoria Literária em paralelo aos da Teoria Musical aqueles que correspondem à hipótese que orienta sua pesquisa: 
Quanto aos procedimentos analíticos, foram estabelecidos a partir de teorias fonológicas e teorias rítmicas musicais, sobretudo, aquelas que constituem os fundamentos de dois modelos adotados: um deles proposto por Nespor e Vogel (1986) e o outro por Fernando Carvalhaes Duarte (1999). O primeiro modelo, constitui-se na base da fonologia prosódica, e foi considerado, principalmente, quanto à sua aplicação na análise rítmico-acentual, na métrica da poesia. Quanto ao segundo - indiretamente ligado à fonologia métrica, e estabelecido sobre a consideração do conceito musical de ritmo destaca-se, ao nosso ver, pela criteriosa correlação dos aspectos métricos/lingüísticos em relação aos aspectos rítmicos/musicais, bem como a sua eficiente adequação às características lingüísticas e musicais próprias da canção. Como aspecto comum aos dois modelos, além de sua eficiência aplicativa, destaca-se o papel desempenhado pela métrica na determinação da acentuação rítmica em ambos os universos aos quais se aplicam: a linguagem verbal poética e a canção. (MATTOS, 2006, p. 14)

O estudo visa aplicações na prática interpretativa, como já nos aponta o próprio resumo inicial:

A principal questão abordada neste trabalho é o tratamento das tensões acentuais entre os acentos decorrentes da periodicidade métrica musical e os acentos rítmico-prosódicos detectados na justaposição dos componentes melódicos verbal e musical da canção. Em nossa hipótese, uma vez identificadas, estas tensões poderiam ser atenuadas ou intensificadas na performance do canto, através do estabelecimento de linhas de interpretação. (MATTOS, 2006, p. 7)

Considera ainda que a fruição também é contemplada:

Portanto, ao trabalharmos sobre o estabelecimento de uma série de procedimentos analíticos com o objetivo de contribuir para a performance da canção, reconhecemos a natureza utilitária destes procedimentos como uma ferramenta acurada a serviço da performance enquanto meios para a manifestação artística e produção de conhecimento, e, ambos estes meios, enquanto ferramentas mais amplas a serviço da fruição. (MATTOS, 2006, p. 13) 
Mattos parte de sua experiência pessoal como cantor, pesquisador e docente, e percebe a necessidade de algum estudo que forneça pistas para lidar com as tensões entre os componentes verbais e musicais presentes principalmente na canção. Escolhe então um objeto de estudo apropriado (as canções de câmara de Claudio Santoro e Vinícius de Moraes), estabelece uma hipótese e, através da análise baseada em pressupostos teóricos lingüísticos e musicais, que aproximam os dois aspectos da canção (o verbal e o musical), coerentes, portanto, com objeto e objetivo, busca a eficiência aplicativa dos procedimentos propostos.

Na conclusão, o autor afirma ter chegado a resultados satisfatórios:

... no contexto das canções analisadas, a configuração de uma ferramenta para a análise dos fenômenos rítmico-prosódicos que resultam da justaposição entre os componentes melódicos verbal e musical, verificou-se eficiente para os propósitos do destacamento de acentos, da identificação de tensões acentuais e da determinação de possíveis linhas de interpretação, na correlação dos diversos níveis da linearidade métrica e prosódica. Sobretudo os efeitos de atenuação e intensificação que se imprimem na oralidade, a partir dos resultados da análise, confirmam-se como uma alternativa para o tratamento das referidas tensões acentuais na performance do canto. (MATTOS, 2006, p. 355)

\subsubsection{3 - As miniaturas musicais de Nilson Lombardi}

\section{Identificação da dissertação:}

\begin{tabular}{|l|l|}
\hline Título & As miniaturas musicais de Nilson Lombardi \\
\hline Autor & Juliano Brito Kerber \\
\hline Nível & Mestrado \\
\hline Ano da defesa & 2007 \\
\hline Orientador & Prof $^{\text {a }}$ Dr $^{\text {a }}$ Dorotéa Machado Kerr \\
\hline
\end{tabular}




\section{Apresentação do sumário da dissertação:}

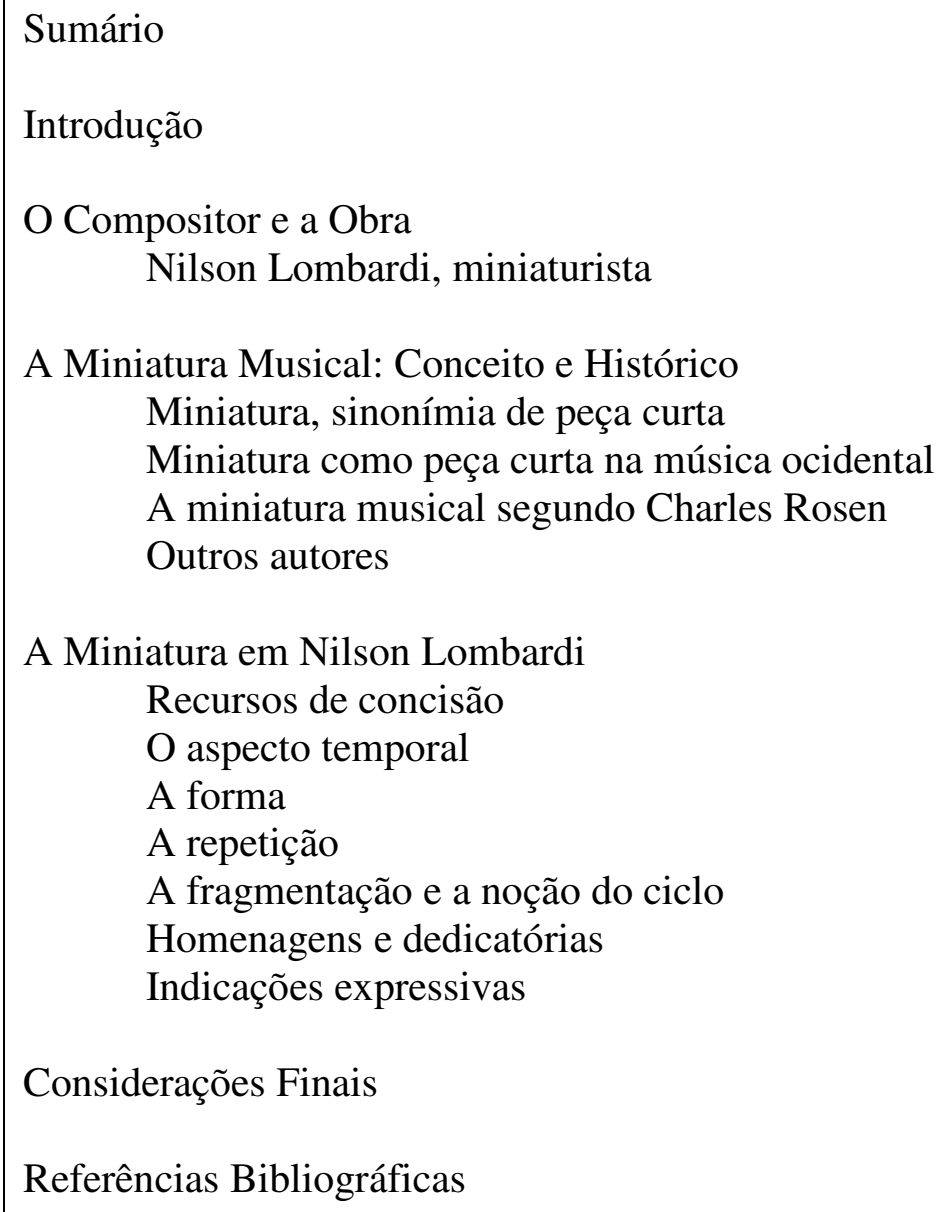

\section{Considerações sobre a dissertação:}

O trabalho de Kerber apresenta, no sumário, uma estrutura organizada logicamente do geral para o particular. A visualização dos diferentes níveis em que se colocam e hierarquizam os assuntos não se faz através de partes ou capítulos numerados. Apenas a disposição espacial é usada como referência.

Há uma Introdução, em que o autor afirma desenvolver-se o trabalho em três partes (os três itens salientados no sumário): O compositor e a Obra; A Miniatura Musical: Conceito e Histórico; A Miniatura em Nilson Lombardi.

Propõe-se a aplicar, ao final, os resultados da reflexão analítica à interpretação.

Quanto aos parâmetros orientadores da pesquisa, afirma que "Adotou-se, pois, uma abordagem qualitativa de maneira a reconhecer a intrínseca interação entre o pesquisador e o fenômeno proposto para estudo". (KERBER, 2007, p. 12) 
E continua mais adiante:

Reconhece-se, então, que na pesquisa qualitativa as propostas podem ser flexíveis, que requerem uma revisão constante da(s) teoria(s) durante o processo e mudanças de acordo com o progresso e as próprias circunstâncias encontradas. Pode-se - e deve-se - improvisar soluções para os problemas de forma flexível e objetiva ... (KERBER, 2007, p. 13)

A primeira parte traça um perfil do compositor, contextualizando-o no panorama da música brasileira. Nilson Lombardi pertence à geração de compositores formados por Camargo Guarnieri. Kerber salienta sua genuína participação e peculiar contribuição nesse contexto, apontando já para alguma especificidade de seu estilo. O conjunto de sua obra também é apresentado.

A segunda parte é dedicada à conceitualização do gênero musical "Miniatura" e sua evolução histórica e utilização por diversos compositores.

A terceira parte dedica-se a analisar os recursos composicionais empregados na elaboração das miniaturas de Nilson Lombardi: recursos de concisão; o aspecto temporal (significando a duração da obra); a forma; a repetição; a fragmentação e a noção do ciclo; homenagens e dedicatórias; indicações expressivas.

É ao discutir o item relativo à repetição que Kerber estabelece certa interação entre a análise e elementos interpretativos. Tais elementos seriam de ordem didática. Lombardi teria empregado o recurso estilístico da repetição aliado à função didática na prática do pianista. Acompanhemos sua explicitação:

A repetição de padrões interfere rapidamente na prática do pianista que irá executá-la. A maioria das obras de Lombardi trabalha um problema específico de execução, como as propostas dos estudos para piano. Dificuldades técnicas ou rítmicas - velocidade, agilidade, saltos, terças, sextas, uníssonos, arpejos, uníssonos para ambas as mãos (como no único estudo que o compositor escreveu), polirritmia, só para citar alguns poucos exemplos - percorrem predominantemente sobre toda uma peça, confirmando o intuito de reunir a obra sobre um único mote-motivo. 
Do corpus total de sua criação, pode-se verificar uma multiplicidade de aspectos pianísticos distribuídos em diferentes exemplos, denotando uma intenção velada de aprimoramento da técnica do piano. É como se o compositor também estivesse disposto a contribuir com o crescimento técnico de seu executante através da exploração de uma ou mais dificuldades típicas de execução. (KERBER, 2007, p. 58)

Outra indicação de ordem interpretativa encontra-se nas Considerações Finais da dissertação, quando se considera que, embora as obras possam ser executadas individualmente, adquirem, no entanto, maior significado quando interpretadas na seqüência indicada pelo compositor:

Nesse sentido, a despeito da execução independente assegurar a presença dessas obras entre os estudantes de piano, para que o sentido essencial e a potencialidade da execução sejam evidenciados, recomenda-se que a apresentação se dê na seqüência determinada pelo compositor, de tal modo que a sucessão de episódios musicais gere um sentido de ampla associação. Confirmando, a apresentação concomitante dessas obras, seja ela em sua totalidade ou em fração do grupo, confere ao conjunto a necessária unidade e lógica. Sem isso, dá-se margem ao incoerente, ao desconexo, ao descontínuo.

Embora algumas justifiquem-se individualmente, a dissimulada efemeridade nem sempre é satisfatória quando executada fora do contexto. De modo geral, a miniatura, enquanto peça autônoma, pode não firmar sua legitimidade se não estiver agregada a uma coleção, a um caderno, a um opus ou a um grupo. É a necessidade do apoio de outra obra (ou do conjunto), para justificar sua existência. Mais: é poder compreendê-la adequadamente somente se dentro de um processo de relativização. (KERBER, 2007, p. 70)

Uma das reafirmações da parte final do trabalho é a de que Lombardi firmou-se esteticamente como miniaturista, associando a esse caráter estilístico um viés didático. 


\subsection{3 - Universidade Estadual de Campinas - UNICAMP}

3.1.3.1 - A escrita para viola nas Sonatas com piano op. $11 n^{\circ} 4$ e op. $25 n^{\circ} 4$ de Paul Hindemith: aspectos idiomáticos, estilísticos e interpretativos

Identificação da dissertação:

\begin{tabular}{|l|l|}
\hline Título & $\begin{array}{l}\text { A escrita para viola nas Sonatas com piano op. 11 no 4 e op. 25 } \\
n^{\circ} 4 \text { de Paul Hindemith: aspectos idiomáticos, estilísticos e } \\
\text { interpretativos }\end{array}$ \\
\hline Autor & Ricardo Lobo Kubala \\
\hline Nível & Mestrado \\
\hline Ano da defesa & 2004 \\
\hline Orientador & Prof. Dr. Emerson Luiz de Biaggi \\
\hline
\end{tabular}

Apresentação do sumário da dissertação:

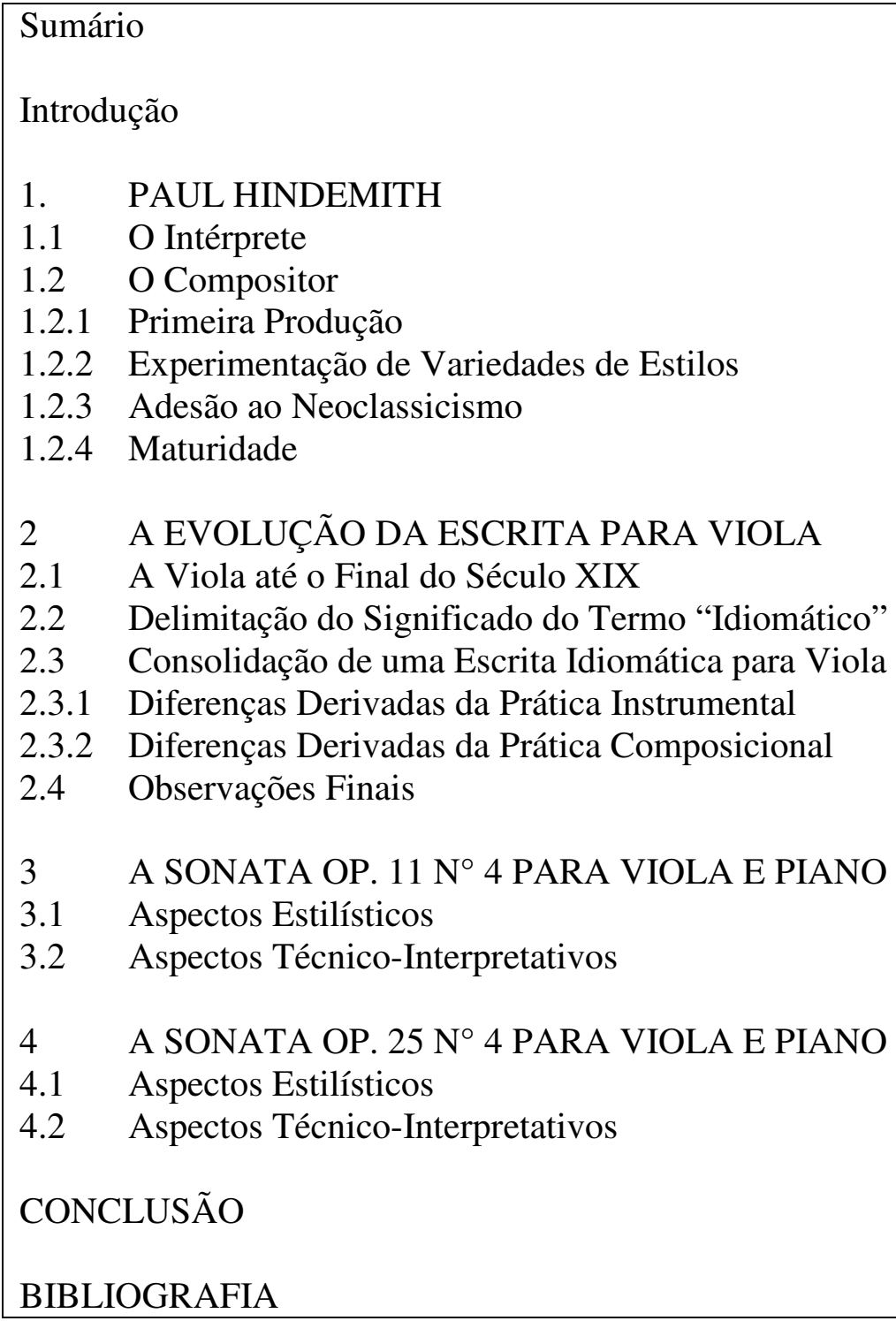




\section{Considerações sobre a dissertação:}

O autor demonstra, logo na introdução do trabalho, a importância, quando se trata de pesquisa em Práticas Interpretativas, de uma metodologia que associe o tema estudado à atividade prática do executante. Salienta que o paradigma qualitativo,

aplicado à pesquisa, é capaz de proporcionar tal associação. Constatemos sobre a metodologia adotada e como a mesma repercutiu nos resultados e na receptividade desse tipo de pesquisa no meio acadêmico, através das próprias palavras de Kubala:

Creio que, na área de práticas interpretativas, seja de maior importância o emprego de uma metodologia que associe o tema estudado à atividade prática do executante. O paradigma qualitativo de pesquisa, ao tomar o pesquisador como principal instrumento de investigação, abriu amplo leque de possibilidades. Aplicado à pesquisa em práticas interpretativas, redundou na aceitação do ato de executar um instrumento como fonte de dados. Outro desdobramento importante foi a melhor receptividade no meio acadêmico à adoção da execução de uma obra, como critério para a avaliação de resultados de uma pesquisa sobre a mesma. Dessa forma, a pesquisa na área de práticas interpretativas tomou um rumo que permite uma leitura do objeto investigado mais em sintonia com a atividade do intérprete. (KUBALA, 2004, p. 18)

Tal metodologia proporcionou partir da prática interpretativa para as constatações de ordem teórica, a fim de elucidar possibilidades técnicas de caráter interpretativo: "A seleção de tópicos abordados foi organizada com base em ordenação de constatações realizadas durante a preparação das sonatas para recital." (KUBALA, 2004, p. 20)

Kubala leva em conta dados biográficos do compositor que repercutem em sua trajetória estilística, questões idiomáticas próprias à viola, aspectos técnicoinstrumentais, enfim, toda a gama de conhecimentos que envolvem o objeto escolhido, com o fim de realizar uma análise ao mesmo tempo detalhada e abrangente da obra selecionada. No caso, a seleção de duas obras de um mesmo compositor, mas que apresentam características contrastantes, propiciou constatações que enriqueceram 
sobremaneira os resultados. A análise embasa as aplicações práticas, confluindo para o estabelecimento dos aspectos técnico-interpretativos detalhadamente expostos.

Na realidade, esta pesquisa realiza uma síntese entre "os estilos do compositor, o estilo por assim dizer, do instrumento e, por fim, o estilo de cada sonata”. (KUBALA, 2004, p. 20)

Uma abordagem com enfoque em estilo mostrou-se útil por sua maleabilidade. Foi possível realizar uma conexão entre a trajetória de Hindemith, os traços estilísticos do mesmo encontrados em cada obra e o idioma do instrumento. O entendimento das motivações do compositor elucida aspectos composicionais, os quais são indicativos de estilo, que convergem com características individuais do instrumento em um todo estilisticamente coerente. (KUBALA, 2004, p. 118)

Extremamente útil para se perceber a que resultados chega tal abordagem, é a transcrição de um trecho das sugestões de interpretação, referente à Sonata Op. $11 n^{\circ} 4$ para viola e piano, em seus compassos iniciais:

... pode-se tocar com ênfase na articulação de mão esquerda, com pouco vibrato e com ponto de contato no arco mais próximo ao espelho, porém com pressão similar à que seria empregada numa passagem em mezzo forte. É uma forma de obter projeção de som ao executar o tema inicial, mesmo em piano, com simplicidade e clareza. (KUBALA, 2004, p. 77-78)

\subsubsection{2 - Almeida Prado: estudos para piano, aspectos técnico-interpretativos}

\section{Identificação da dissertação:}

\begin{tabular}{|l|l|}
\hline Título & $\begin{array}{l}\text { Almeida Prado: estudos para piano, aspectos técnico- } \\
\text { interpretativos }\end{array}$ \\
\hline Autor & Carlos Alberto Silva Yansen \\
\hline Nível & Mestrado \\
\hline Ano da defesa & 2005 \\
\hline Orientador & $\begin{array}{l}\text { Prof }{ }^{\text {a }} \text { Dr }^{\mathbf{a}} \text { Aci Taveira Meyer e Prof } \\
\text { Machado Pascoal }^{\text {a }} \text { Maria Lucia Senna }\end{array}$ \\
\hline
\end{tabular}




\section{$\underline{\text { SUMÁRIO - DIVISÃO EM CAPÍTULOS }}$}

LISTA DE TABELAS

LISTA DE EXEMPLOS

LISTA DE ABREVIATURAS

INTRODUÇÃO

\section{CAPÍTULO 1: O ESTUDO PARA PIANO}

1.1. Considerações gerais sobre o Estudo para piano

1.2. Estudos na Música Brasileira

\section{CAPÍTULO 2: ALMEIDA PRADO E OS ESTUDOS PARA PIANO}

2.1 Os Estudos para piano dentro da obra de Almeida Prado

2.2 Os Estudos pelo compositor

CAPÍTULO 3: ALMEIDA PRADO: 14 ESTUDOS PARA PIANO: ANÁLISE E ASPECTOS RELACIONADOS À TÉCNICA PIANÍSTICA E À INTERPRETAÇÃO

3.1 Estudo ${ }^{\circ} 1$ - Embolada

3.1.1 Análise da Estrutura

3.1.2 Sugestões para a Interpretação

3.2 Estudo $n^{\circ} 2$

3.2.1 Análise da Estrutura

3.2.2 Sugestões para a Interpretação

3.3 Estudo ${ }^{\circ} 3$

3.3.1 Análise da Estrutura

3.3.2 Sugestões para a Interpretação

3.4 Estudo $\mathrm{n}^{\circ} 4$

3.4.1 Análise da Estrutura

3.4.2 Sugestões para a Interpretação

3.5 Estudo $^{\circ} 5$ - Três Profecias em forma de Estudo - Profecia 1

3.5.1 Análise da Estrutura

3.5.2 Sugestões para a Interpretação

3.6 Estudo $\mathrm{n}^{\circ} 6$ - Três Profecias em forma de Estudo - Profecia 2

3.6.1 Análise da Estrutura

3.6.2 Sugestões para a Interpretação

3.7 Estudo $\mathrm{n}^{\mathrm{o}} 7$ - Três Profecias em forma de Estudo - Profecia 3

3.7.1 Análise da Estrutura

3.7.2 Sugestões para a Interpretação

3.8 Estudo $n^{\circ} 8$ - Tríptico de Claude Monet - Arcos Melodias e ressonâncias

3.8.1 Análise da Estrutura

3.8.2 Sugestões para a Interpretação

3.9 Estudo $n^{\circ} 9$ - Tríptico de Claude Monet - Vibrações e Ondulações

3.9.1 Análise da Estrutura

3.9.2 Sugestões para a Interpretação

3.10 Estudo no 10 - Tríptico de Claude Monet - Sombras e Luzes - Florações

3.10.1 Análise da Estrutura

3.10.2 Sugestões para a Interpretação 


\begin{tabular}{|l|}
\hline 3.11 Estudo ${ }^{\circ} 11$ - As Begônias do Quintal Celeste \\
3.11.1 Análise da Estrutura \\
3.11.2 Sugestões para a Interpretação \\
3.12 Estudo ${ }^{\circ}$ 12 - Moto Perpétuo - Toccata \\
3.12.1 Análise da Estrutura \\
3.12.2 Sugestões para a Interpretação \\
3.13 Estudo n 13 - Étude de Couleurs en forme de "patchwork" pour le piano \\
3.13.1 Análise da Estrutura \\
3.13.2 Sugestões para a Interpretação \\
3.14 Estudo no 14 - A Maneira de Siciliana \\
3.14.1 Análise da Estrutura \\
3.14.2 Sugestões para a Interpretação \\
CONCLUSÃO \\
GLOSSÁRIO \\
BIBLIOGRAFIA \\
ANEXOS
\end{tabular}

\section{Considerações sobre a dissertação:}

A observação do sumário deste trabalho oferece-nos uma nítida perspectiva de sua estrutura, estrutura esta que se desenvolve de forma objetiva no decorrer do texto, revelando-se coerente com a pesquisa.

Após discorrer sobre o gênero "Estudo" na sua especificidade para piano, focaliza os Estudos para piano na Música Brasileira, para depois situá-los na obra de Almeida Prado.

Sustentam a investigação: execução das peças, estudo analítico das mesmas e o contato com o compositor. Adotou-se, para estruturar e administrar os dados, o modelo adaptado de John White em Comprehensive Musical Analysis, recorrendo-se, para a análise melódica, à terminologia de Arnold Schoenberg em Fundamentos da Composição Musical.

O contato direto com o compositor, segundo palavras do próprio Yansen, foi de capital importância: "O segundo [capítulo] é composto por uma entrevista com o compositor onde ele detalha quais as circunstâncias da composição das peças, quais aspectos o motivaram e quais eram suas intenções no momento da criação". (YANSEN, 2005, p. 11) 
Na conclusão, reafirma a importância desse contato:

Outro passo importante foi o contato com o compositor e a troca de informações quanto à sua versão no que se refere ao como executar suas obras.

O estudo ao piano, a análise, aliados às informações coletadas junto ao compositor Almeida Prado, puderam nos levar à organização metódica de sugestões para solucionar problemas de ordem técnico-interpretativos, que comumente são encontrados pelos executantes. (YANSEN, 2005, p. 189)

Ilustramos, a seguir, esse contato, com pequeno trecho da entrevista concedida por Almeida Prado ao autor da pesquisa, e que consta do capítulo 2, referente ao Estudo $n^{o} 1$ - Embolada:

$\mathrm{Na}$ verdade é um Estudo sobre polifonia e ritmos sobrepostos. O pianista que pretende estudar tem que ter uma grande independência dos dedos para fazer ressaltar, ora a voz superior, ora a do meio, ora a inferior, como se fosse um contraponto "Bachiano". (PRADO apud YANSEN, 2005, p. 3637)

É para o capítulo 3 que converge todo o trabalho de pesquisa. Cada Estudo ocupa um item deste capítulo. E, em cada um, Yansen procede, num primeiro momento, à análise da estrutura do Estudo, confeccionando um quadro em que focaliza os elementos analisados dentro das perspectivas de macro, média e micro análise, e explicando-o dissertativamente em seguida. Num segundo momento, após elencar as dificuldades técnico-interpretativas, advindas da análise, dos subsídios coletados junto ao compositor e do contato direto com o material musical, são feitas sugestões para interpretação, considerando, inclusive, formas didáticas de aprimoramento da técnica necessária à execução dos trechos que apresentam as referidas dificuldades.

Eis uma amostra dessas sugestões, em relação ao Estudo no 2 - "Para as oitavas”:

A dificuldade em se executar oitavas é grande em qualquer circunstância. No entanto há algumas considerações a respeito da técnica pianística sobre como trabalhar esta dificuldade. Primeiramente é necessário lembrar que 
qualquer, não importa qual seja o intervalo harmônico a se tocar, deve-se observar onde está a linha melódica. Neste caso, a nota superior da oitava possui esta linha. Deve-se timbrá-la mais que a linha inferior. Sugere-se prender a nota inferior e repetir por algumas vezes a superior com o intuito de adquirir força nos dedos que executam esta voz ... (YANSEN, 2005, p. 61)

Na conclusão, além de reafirmar o que já se estabelecera no decorrer do trabalho, são apontadas outras contribuições que dele decorrem, tais como:

Concluímos também que o conjunto de Estudos reúne grande parte das dificuldades técnico-pianísticas abordadas pelo compositor no restante de sua obra. Desta forma, se deduz que o estudo sistemático destas peças pode dar subsídios para a interpretação de grande parte da obra escrita por Almeida Prado. (YANSEN, 2005, p. 191)

Esta pesquisa revelou ainda modificações na execução das peças de Almeida Prado anteriores e posteriores a ela, pela tomada da consciência dos elementos da construção musical e pelos procedimentos para a superação de problemas técnicos estudados, com o intuito de dominar as dificuldades técnico-interpretativas impostas pela execução. (YANSEN, 2005, p. 192)

\subsubsection{3 - Questões estruturais e interpretativas na obra pianística de Ricardo Tacuchian}

\section{Identificação da dissertação:}

\begin{tabular}{|l|l|}
\hline Título & $\begin{array}{l}\text { Questões estruturais e interpretativas na obra pianística de } \\
\text { Ricardo Tacuchian }\end{array}$ \\
\hline Autor & Midori Maeshiro \\
\hline Nível & Doutorado \\
\hline Ano da defesa & 2007 \\
\hline Orientador & $\begin{array}{l}\text { Prof. Dr. Mauricy Matos Martin e Prof } \\
\text { Machado Pascoal }\end{array}$ \\
\hline
\end{tabular}




\section{SUMÁRIO}

Página de aprovação

Agradecimentos

Resumo

Abstract

Abreviaturas

Lista de tabelas

Lista de figuras

INTRODUÇÃO

\section{CAPÍTULO 1 - O COMPOSITOR}

1.1) Sobre as fases do compositor

1.2) Sobre o Sistema-T

1.2.1) As alturas na escala-T

1.3) Elementos da música (segundo próprio compositor)
1.3.1) Ritmo
1.3.2) Harmonia
1.3.3) Melodia
1.3.4) Estrutura

1.4) Questão idiomática para piano

1.4.1) Sobre as obras para piano

\section{CAPÍTULO 2 - ANÁLISE DA OBRA PIANÍSTICA}

Primeira Sonata para piano (Rio de Janeiro, 1966) manuscrito Segunda Sonata para piano (Rio de Janeiro, 1966) manuscrito Estruturas Gêmeas (Rio de Janeiro, 1978) manuscrito Il Fait du Soleil (Rio de Janeiro, 1981) manuscrito Retreta (Rio de Janeiro, 1986) manuscrito Capoeira (Rio de Janeiro, 1997) edição do Autor Avenida Paulista (Rio de Janeiro, 1999) edição do Autor Aquarela (Rio de Janeiro, 2001) edição do Autor Lamento pelas crianças que choram (Lisboa, 2003) edição do Autor Manjericão (Rio de Janeiro, 2003) edição do Autor Leblon à Tarde (Rio de Janeiro, 2003) edição do Autor XIII Passo da Via-sacra (Rio de Janeiro 2005) edição do Autor In Memorian a Lopes-Graça (Rio de Janeiro 2006) edição do Autor Água-forte (Rio de Janeiro 2006) edição do Autor Reply to Christopher Bochmann (Rio de Janeiro 2006) edição do Autor Arcos da Lapa (Rio de Janeiro 2007) edição do Autor Vitrais (Rio de Janeiro 2007) edição do Autor 
CAPÍTULO 3 - ASPECTOS DE PREPARAÇÃO PIANÍSTICA PARA A PERFORMANCE do piano

3.1 Condição mental: comentários de textos sobre os processos de estudos

3.2 A técnica: considerações sobre o toque pianístico

3.3 A memorização: considerações sobre estudo de memorização aplicado a cada peça

3.4 Performance: para uma interpretação da obra

3.4.1 Comparações entre termos

3.4.2 Sugestões para interpretação de símbolos gráficos e sinais

3.4.3 Dificuldades e soluções

\section{CONCLUSÃO}

Bibliografia

Anexos

1) Glossário

2) Artigo de Ricardo Tacuchian sobre o Sistema-T

3) Textos originais

\section{Considerações sobre a dissertação:}

O perfil deste trabalho é marcado pela busca de interação entre análise e performance. O objeto é toda a obra pianística de Ricardo Tacuchian. O próprio título já nos indica: "Questões estruturais e interpretativas na obra pianística de Ricardo Tacuchian".

Nesse intuito, adotou um esquema que parte da contextualização da referida obra, suas fases, o Sistema-T criado e empregado pelo compositor como ferramenta, os elementos da música (ritmo, harmonia, melodia, estrutura), a questão idiomática quanto ao piano. Toda essa fundamentação é fornecida pelo próprio compositor. Uma entrevista concedida por ele e transcrita no primeiro capítulo aborda, passo a passo, todos esses elementos. Fornece importantes dados para a posterior análise das peças e as considerações quanto à performance. Diz Maeshiro: "O primeiro capítulo através da entrevista com o próprio compositor, elabora a sua visão em relação às fases composicionais, aos elementos musicais e à sua obra". (MAESHIRO, 2007, p. 6) 
O segundo capítulo dedica-se à análise da obra pianística de Tacuchian. Utilizam-se diferentes ferramentas, selecionando-se, para cada obra, as que melhor se lhe adaptam. Na introdução ao trabalho, já se afirma:

Foram utilizadas as seguintes técnicas de análise:

- Estudo das pequenas unidades musicais com base na lógica e coerência.

- Análise da estrutura através de sínteses contrapontísticas apresentadas como vozes condutoras.

- Teoria dos conjuntos de sons.

(MAESHIRO, 2007, p. 5)

No início desse segundo capítulo, precedendo a análise propriamente dita, essas técnicas são delineadas e explicitadas em subitens, que tratam de cada uma. Podemos assim sintetizá-las:

- A primeira é a análise da estrutura através dos motivos, baseada nos Fundamentos da Composição Musical de Arnold Schoenberg.

- A segunda refere-se a vozes condutoras e baseia-se em Structural hearing, de Felix Salzer.

- A terceira é a Teoria dos Conjuntos, encontrada em Introduction to post-tonal theory, de Joseph Straus. (MAESHIRO, 2007, p. 25-26)

A ordem da análise segue a cronologia das obras, mas seis delas são escolhidas como representativas, abarcando as várias fases criativas do compositor, e sobre elas incide uma análise mais detalhada.

Nas demais peças aplicam-se os conceitos de macro/média e micro análise, técnica proposta por John White, em Comprehensive musical analysis, valorizando elementos como: altura, ritmo, dinâmica, timbre e textura. (MAESHIRO, 2007, p. 27 28)

Maeshiro elabora um quadro demonstrativo, elencando as peças e as técnicas que serão empregadas na análise de cada uma. Consta ainda desse quadro uma coluna indicativa da década em que cada peça foi composta. Junto ao título de cada peça vem anotado o ano de sua composição. O quadro ainda salienta em vermelho as seis obras escolhidas como representativas. 
A seguir, cada obra é analisada, apresentando-se primeiramente sua ficha técnica, seguindo-se considerações sobre a peça. Indica-se então o que se pretende apresentar na análise (material utilizado pelo compositor e aspectos responsáveis pela unidade da peça) e as técnicas que serão utilizadas. A análise propriamente dita é apresentada, de cunho exaustivo, através de quadros e figuras demonstrativas e considerações sobre os materiais e estruturas utilizados. Culmina com síntese conclusiva.

No terceiro capítulo - Aspectos da Preparação Pianística - Maeshiro faz de início colocações relativas à inseparabilidade entre os aspectos artístico e técnico, considerando ainda que:

A interdependência entre técnica instrumental, sensibilidade $\mathrm{e}$ conhecimento do conteúdo musical constitui-se em um processo único, ligado à competência e à criatividade na arte de como estudar. Os processos do estudo do piano irão delinear maior ou menor grau de liberdade e fidelidade à interpretação musical, refletindo diretamente no produto final da pesquisa - a performance. (MAESHIRO, 2007, p. 149)

A seguir, antes de tratar dos aspectos concernentes à performance das obras analisadas, são abordados fundamentos pianísticos em que se baseia o trabalho, a saber: a condição mental, a técnica e a memorização.

Quanto, especificamente, à performance, termo cuja significação mescla-se e confunde-se com os termos "execução" e "interpretação" em muitos contextos, a autora define em que sentido o emprega neste trabalho. Recorre à diferenciação estabelecida por Stravinsky em Poética Musical em 6 Lições, quanto a "execução" (aspectos mecânicos) e "interpretação" (tornar sensível ao ouvinte o conteúdo da partitura). Assim caracteriza neste trabalho performance:

A performance musical começa por integrar estes dois aspectos [execução e interpretação] e sendo assim, apresenta aspectos técnicos dessa prática musical e ao mesmo tempo, os processos interpretativos que contribuem para essa ação. A performance é um fazer artístico que integra conhecimento racional e intuitivo, tradição, emoção, sensibilidade, história, 
contemporaneidade e cultura do executante. (MAESHIRO, 2007 p. 159160)

Como contribuição prática, a partir da análise das peças, tendo em vista a performance, elabora "Sugestões para interpretação de símbolos gráficos e sinais". Agrupa tais sugestões em torno dos aspectos relacionados a: andamento, ritmo, dinâmica, melodia, pausas, oitavas, bordão, arpejo, síncopa.

Outra contribuição, sob o subtítulo "Dificuldades e soluções", finaliza o capítulo, evidenciando dificuldades e soluções em relação a cinco peças analisadas.

A Conclusão faz uma síntese de todo o conteúdo desenvolvido, reafirmando de várias maneiras a importância de se integrar análise e performance. Salientamos o seguinte trecho:

Espera-se que este trabalho possa incentivar a linha de investigação interdependente - a interação entre análise e performance - abrindo uma nova forma de comunicação e deixando o velho clichê em que os performers são aqueles que fazem música e os analistas, aqueles que falam meramente sobre a obra. (MAESHIRO, 2007, p. 188)

\section{2 - Tendências detectadas nos trabalhos}

As considerações levantadas no item anterior proporcionaram detectar algumas tendências das pesquisas em suas abordagens.

Há uma tendência presente nos trabalhos que demonstra interesse pela pesquisa de obras de compositores brasileiros. Entre os nove trabalhos selecionados, apenas um foge a este princípio. Trata-se do trabalho de Kubala, sobre as sonatas op. $11 \mathrm{n}^{\circ} 4$ e op. $25 \mathrm{n}^{\circ}$ 4, de Paul Hindemith. Tal tendência contribui para a valorização e divulgação desse nosso importante patrimônio cultural.

O fato de se dedicar a obras de compositores brasileiros favorece, por um lado, o acesso do pesquisador a determinadas fontes, tais como o contato com descendentes, familiares, amigos, alunos ou o próprio compositor. Por outro lado, a bibliografia sobre 
compositores brasileiros ainda é bastante limitada se comparada àquelas disponíveis sobre a vida e a obra de compositores estrangeiros de grande vulto. Em duas das dissertações estudadas podemos notar que houve contato direto com os compositores, pois até mesmo as palavras destes fazem parte do texto. Trata-se, no trabalho de Yansen, de Almeida Prado discorrendo sobre as circunstâncias em que foi composto cada Estudo, quais aspectos o motivaram para cada uma dessas composições, e quais eram suas intenções no momento da criação. Da mesma forma, considerações sobre aspectos da própria obra são oferecidos por Ricardo Tacuchian, constituindo todo um capítulo da dissertação de Maeshiro. Já Lessa inclui como apêndice, ao final do texto, entrevista com Osvaldo Lacerda, compositor da Missa Ferial, objeto de sua pesquisa.

Percebe-se, com efeito, sob a forma de contato direto ou valendo-se de outras formas de pesquisa, forte predominância da estratégia de se proceder, como ponto de partida para o desenvolvimento do trabalho, ao levantamento e apresentação de dados biográficos do compositor, o que proporciona também a caracterização do momento histórico em que as obras foram concebidas. Esses elementos estão sempre a serviço de uma inserção e caracterização da obra analisada num contexto histórico e estético, o que não deixa de ser relevante para sua apreensão e, conseqüentemente, oferece subsídios à interpretação. $\mathrm{O}$ aproveitamento desses dados em maior ou menor escala dependerá de diversos fatores inerentes à peculiaridade de cada abordagem.

Estratégias outras orientaram as pesquisas de Apro e Mattos.

Apro parte de uma situação-problema, vivenciada em sua própria atuação como violonista. As orientações contrastantes que teve em sua formação, quanto à linha a imprimir à interpretação, impulsionaram-no na busca de um método investigativo. $\mathrm{O}$ questionamento quanto a priorizar a fidelidade ao texto do compositor ou a liberdade criativa, levou-o a uma fundamentação estético-filosófica para o trabalho, a qual fez incidir sobre o objeto de estudo. Apro realizou uma revisão da bibliografia de Mignone, bem como das diferentes versões dos 12 Estudos para Violão, oferecendo ainda sua própria versão, na qual tentou ser o mais fiel possível à versão autógrafa. Traçou sugestões para resolver aspectos técnicos, procedeu a uma análise de caráter hermenêutico aplicada a propostas interpretativas.

Mattos detecta um problema específico de interpretação: a tensão rítmicoprosódica entre os elementos verbal e musical presente nas canções. Busca 
fundamentação nas teorias fonológicas e rítmicas musicais, valendo-se, pois, da interdisciplinaridade, aliando a Lingüística e a Teoria Literária à prosódia musical. Elege um objeto sobre o qual faz incidir um modelo de análise específico que constrói a partir dessa fundamentação lingüístico-musical: as canções de câmara de Claudio Santoro e Vinícius de Moraes. Estabelece linhas de interpretação para essas canções, sugerindo formas de atenuar ou intensificar os momentos em que a tensão entre os elementos verbal e musical se apresenta.

A interação entre pesquisa e prática musical é outra constante que se depreende da leitura dos trabalhos. De forma mais ou menos detalhada, com maior ou menor adensamento de informações, fazem-se propostas, sugestões, apontamentos relativos à interpretação. Execução da obra como ponto de partida para a pesquisa, transformações na forma de execução decorrentes da pesquisa, descrição de aspectos práticos de preparação para a performance confirmam essa interação. De alguns constam gravações como anexos, resultantes de trabalhos diretos do pesquisador em performances envolvendo tais propostas. São iniciativas que indicam certa tendência de se adotar a execução de uma obra para demonstrar resultados.

A análise das obras, embora variando quanto a enfoque e abordagem, é ferramenta utilizada por todos os pesquisadores para identificar os principais elementos capazes de orientar a performance. Aponta para a tendência das pesquisas em promover a interação entre análise e interpretação.

\section{3 - Análise e Interpretação}

Uma das questões sempre referidas quando se trata de estudos acadêmicos sobre interpretação é a relação entre esta e a análise. Há informações que são tidas como úteis por praticamente todos os intérpretes e poucos seriam os que se oporiam a elas. Contextualização histórica, um painel social e cultural da época em que a obra foi composta, a ocasião e mesmo o local para o qual a obra foi pensada podem, realmente, ajudar o intérprete a entender melhor o pensamento do compositor. Eventualmente, a biografia do compositor também pode contribuir. 
Se soubermos, por exemplo, que determinada obra foi composta para ser executada numa igreja, podemos imaginar que a duração dos sons e sua articulação levem em conta, muito provavelmente, o tempo de reverberação maior que este ambiente possui em relação a uma sala onde se faz música de câmara. Se soubermos que um determinado fato, importante e determinante na biografia do compositor, motivou a composição de uma obra específica, considerações sobre o peso dramático que deva a ela ser proporcionado podem ser tecidas. Isso também pode amparar escolhas sobre andamentos, articulações, etc. Se somos informados de que uma peça foi composta para uma cidade sitiada ou ameaçada pela guerra, ou em estado de guerra, ou se, pelo contrário, sabemos que se trata da coroação de um rei ou da celebração de uma grande vitória, tudo isto pode afetar a maneira como "lemos" a obra.

Entretanto, nada disso poderá substituir o estudo da obra mesma, ou seja, prioritariamente, o que está em jogo são as informações contidas na partitura. E, para desvendar relações contidas nela, costuma-se realizar uma análise. Em sua acepção costumeira, análise em música normalmente associa-se a procedimentos de determinação das seções da obra e suas subdivisões (análise formal), da estrutura de acordes que sustenta a obra (análise harmônica) e mesmo da maneira como as dissonâncias são utilizadas (análise contrapontística). Também temos a análise de temas e motivos e a análise fraseológica (normalmente associadas à análise formal), análise da instrumentação, e ainda muitas outras.

Podemos justificar, por exemplo, que um determinado trecho musical deva ser marcado por uma diferenciação timbrística, para realçar a passagem para uma nova seção formal. Podemos alterar a agógica de certo trecho com vistas a valorizar o aparecimento de um acorde ou a utilização de uma dissonância específica. Uma análise também pode fornecer a correlação entre elementos aparentemente dispersos na obra, oferecendo possibilidade de buscar coerência e proporção entre andamentos, articulações, o que pode garantir um maior equilíbrio na execução musical. Quanto à música do século XX e à música contemporânea, na qual muitas vezes travamos contato com uma organização menos conhecida do material musical, a análise pode proporcionar o entendimento necessário para que o intérprete sinta-se seguro.

Mas, em toda análise, o que parece estar em jogo, principalmente, é perceber "o que o compositor quis dizer", tentar decifrar o pensamento musical (e os sentimentos?) 
que o compositor expressa naquela obra, ou, seguindo o senso comum, "qual é a sua mensagem".

Também há uma premissa, geralmente aceita, de que o intérprete deve compreender aquilo que executa, que os músicos devam entender o que tocam. Aqui, cabe uma metáfora com a linguagem, na qual um declamador ou orador apenas possuiria a devida autoridade em seu discurso se soubesse compreender, em toda sua extensão e profundidade, o alcance daquilo que fala. Tem-se como certo que, sem absorver verdadeiramente o conteúdo daquilo que deseja proclamar, um declamador não seria capaz de dar a devida entonação às frases, de alterar o tom de voz (em certos momentos oportunos), de fazer pausas e acentos, de alterar a velocidade e o ritmo com que lê ou discursa. Paralelamente, também o músico, sem analisar uma peça, estaria menos hábil em transmitir e comunicar aos seus ouvintes as nuances do texto que interpreta.

E, por fim, havemos de relatar certo preconceito que teima em pairar sobre a real capacidade de análise dos intérpretes. Teóricos, dotados das ferramentas analíticas, estariam supostamente mais aptos a alcançar verdades às quais os intérpretes, meros repetidores de repertório e menos equipados e propensos ao ato analítico, não teriam acesso. Devido ao exaustivo trabalho motor e técnico cobrado do intérprete, supostamente teria ele abdicado de "pensar a música".

Entretanto, havemos de perguntar se o conhecimento gerado pelo processo analítico é o único realmente importante quando se trata de pensar a interpretação, e, portanto, se coisa alguma do trabalho normalmente realizado pelo intérprete, em seu estudo da obra, pode contribuir para isso. E essa questão foi assim formulada por Joel Lester:

É correto assumir que todas aquelas dezenas de milhares de horas que os intérpretes gastam desenvolvendo suas habilidades são inteiramente sem sentido, e que é somente quando uma informação derivada cognitivamente é exposta em palavras que as habilidades dos intérpretes são hábeis para criar interpretações válidas? (LESTER, 1995, p. 198, tradução nossa) 
As inúmeras horas de estudo gastas pelos intérpretes para chegarem ao domínio técnico necessário à execução de uma obra estariam à margem desse processo, não sendo capazes de gerar nenhum conhecimento da obra? Certamente, deve haver um conhecimento específico, não verbal e ainda não mormente documentado, nascido durante este processo de preparação da obra, que se origina do contato direto com ela e que pode conter informações que guiem a interpretação, tanto quanto as análises tradicionais.

Outra ressalva ainda poderia ser feita: a análise é, ela mesma, um recorte da obra, feito a partir de um ponto de vista específico. Portanto, a análise, por mais abrangente que seja, não possui a verdade completa sobre a obra, e mesmo os teóricos concordam que há análises diferentes e verdadeiras que podem ser tecidas sobre uma mesma obra, basta que se mude o foco. E, sendo assim, não pode a análise ser a única fonte de entendimento acerca de uma obra. Na música estão contidas informações tão diversas e ricas que, ao transportar para o universo analítico estes elementos, algo sempre se perde; isso implica em reconhecer a especificidade própria da música, ou seja, que ela não poderá jamais ser transformada em linguagem racional ou lógicoanalítica sem que se perca algo.

E se analisar significa "por em foco" determinados aspectos, podemos igualmente aceitar que interpretar uma obra também o é, visto que, a exemplo da análise, nenhuma interpretação exaure todas as possibilidades expressivas de uma obra. Aceitando, pois, que a interpretação de uma obra significa realizar uma série de escolhas que vão além do que está efetivamente grafado na partitura (nuances de andamento, articulação e timbres, por exemplo), a escolha do que será valorizado pelo intérprete, mesmo se feita de maneira mais intuitiva do que racional, também significa "por em foco" determinados aspectos, tal como uma análise tradicional o faz. Lester assim se posicionou sobre este assunto:

Intérpretes não precisam necessariamente verbalizar ou mesmo pensar conscientemente sobre essas questões [analíticas], mesmo para si próprios, na privacidade de suas salas de estudo. Nem tratam delas, necessariamente (seja conscientemente ou não) com o propósito de entender como uma peça é engendrada, como ela 'funciona', como isso pode ser mostrado para exemplificar uma estrutura particular ou como ela é redutível às estruturas 
mais fundamentais. Ou seja, seu objetivo não é, necessariamente, analisar a peça. (LESTER, 1995, p. 207, tradução nossa)

Portanto, o que parece estar em foco é a detecção de qual tipo de conhecimento ampara a interpretação, mesmo quando este conhecimento não é plenamente reconhecível a partir dos pressupostos acadêmicos. Ou seja, algo que possa ser entendido como criado a partir de impulso espontâneo possuiria, insuspeitadamente, certo grau de conhecimento. Conhecimento este que o guiaria para a busca da coerência e poderia tornar a interpretação coerente.

Não defendemos aqui que a análise tradicional não possa lançar luz sobre aspectos interpretativos, mas questionamos se ela é a única detentora dos mecanismos que permitiriam isso. Que a análise seja uma das ferramentas úteis que podem auxiliar o intérprete não está em jogo, mas sim que outros procedimentos, mesmo os que escapam ao domínio lógico-racional também possam ser levados em consideração, e, ainda, que tipo de análise seria a mais adequada para fins de interpretação.

William Rothstein, na conclusão de seu artigo Analysis and the act of performance, assim se expressou sobre os tipos de análise que julga os mais adequados para esta finalidade:

Tenho sugerido quatro [tipos de análise] neste capítulo: análise baseada em temas e motivos; análise métrica (incluindo versificação musical); análise fraseológica; e análise da voz principal do tipo Schenkeriana. A análise harmônica tradicional não foi incluída aqui, embora faça parte de todas as abordagens que citei, e a lista não é, de qualquer forma, exaustiva (textura, por exemplo, não foi incluída). Realce exclusivo em determinado aspecto pode ser perigoso, como tenho argumentado; a análise deve conduzir à síntese. (A análise da voz principal tem a virtude de ser, por essência, sintética, mas mesmo ela, sozinha, não é suficiente.) Cada abordagem tem muito com que contribuir, se realizada de maneira sensata, e cada uma pode servir como antídoto para as outras. Cada uma pode ajudar, também, na construção da história que o intérprete nos contará. (ROTHSTEIN, 1995, p. 238, tradução nossa) 
E agora poderemos também responder à questão anteriormente delineada, acerca da desconfiança que, talvez, persista sobre as habilidades e capacidades analíticas por parte dos intérpretes. E o faremos citando Felipe Avellar de Aquino:

O incremento da produção bibliográfica ajudou a derrubar o mito, injustamente criado, de que o interprete não tem capacidade de reflexão nem de articular suas idéias. Ademais, a qualidade de muitas destas publicações vem comprovar a importância da visão do intérprete em relação ao seu repertório. É verdade que muitos criticavam a visão analítica ou musicológica do intérprete. Hoje, no entanto, há um consenso sobre a relevância da abordagem analítica voltada para interpretação, ou seja, a importância da aplicação de ferramentas analíticas capazes de subsidiar e oferecer soluções práticas para os problemas interpretativos. O crescimento da produção bibliográfica na sub-área de práticas interpretativas segue, na verdade, o que já vem a ser uma tendência internacional. (AQUINO, 2003, p. 105)

E, para além dessas idéias, outra ainda poderá aprofundar nosso questionamento acerca das relações entre análise e interpretação. Nos textos de Lester e Rothstein, mais enfaticamente no primeiro do que no segundo, pode-se notar certa tendência em justificar que a análise não deve, isoladamente, indicar os caminhos para a interpretação. Isso parece revelar, pelo menos no que diz respeito à realidade que cerca estes autores, que deve haver certa pressão para que a interpretação coadune-se com a análise de determinada peça.

Mas, em última instância, por que caberia à análise validar uma interpretação? Se os teóricos, supostamente, esperam que interpretações venham a sublinhar aspectos que a análise parece demonstrar, e chegam a julgar interpretações por este parâmetro, o que garantiria à análise esta primazia? Se assim é, seria igualmente razoável que se esperasse, portanto, que uma análise viesse a ser considerada válida se e somente se os pressupostos que carrega pudessem ser confirmados pela (ou por uma) interpretação. Afinal, se alguns teóricos anseiam por uma interpretação que demonstre exemplarmente aspectos analíticos, seria justo permitir aos intérpretes que esperassem encontrar, dentre as análises existentes, uma que se coadunasse com suas escolhas interpretativas.

Acreditamos que a análise basta por si mesma, constituindo matéria digna, plenamente procedente e valorada enquanto objeto de estudo. Análise não se mostra 
mais ou menos "correta" apenas se, a partir dela, puderem ser retiradas premissas interpretativas. O que justifica a análise não é uma interpretação que nela se apóie e se mostre convincente, esta não é a instância que a legitima. E, do mesmo modo, a interpretação não necessita que uma análise venha a dar-lhe chancela, pois que não é sua juíza. Uma interpretação, para ser convincente, não precisa ser corroborada por uma análise, embora o possa na maioria dos casos. Mas, se queremos relacionar interpretação e análise de maneira a elevar ambas, percebamos que elas têm muito a dividir, desde que esse diálogo se faça em condições de equilíbrio. 


\section{CONCLUSÃO}

Depois de vencidas as etapas todas de nossa pesquisa, conclui-se ter ela sido realmente oportuna. Os dados levantados confirmaram o que já percebíamos de forma assistemática: ausência de uma formalização, dentro dos programas de pós-graduação em Música, necessária para atender às peculiaridades das Práticas Interpretativas, formalização essa que visasse à diferenciação que a especialidade exige.

E, quanto a isso, relembremos o que foi constatado no corpo do trabalho sobre o assunto: as universidades, ao organizar os programas, observam as premissas orientadoras do órgão competente (CAPES), mas necessitam levar em consideração a realidade do corpo docente. Daí a diversidade de formas em que os diversos segmentos de cada área (no caso, os segmentos da Música) aparecem inseridos nos programas.

Como se depreende, principalmente a partir do primeiro capítulo, Práticas Interpretativas está ainda à procura de seu lugar no âmbito da pesquisa acadêmica. Como se constatou, apenas na UNICAMP há uma área de concentração dedicada especificamente a Práticas Interpretativas, com duas linhas de pesquisa próprias. Na USP, figura sob a terminologia "Questões Interpretativas", como parte da linha de pesquisa pertencente à área de concentração "Processos de Criação Musical". Na UNESP, há uma área de concentração denominada "Interpretação/Teoria e Composição", que comporta como linha de pesquisa "Epistemologia e Práxis do Processo Criativo”. Ou seja, a subárea não possui espaço delimitado, a ela consagrado, tal como possui, por exemplo, a área de Musicologia.

E este quadro reflete claramente uma identidade ainda em construção, construção essa que passa, obviamente, pelo enfrentamento de desafios. São desafios semelhantes e mesmo decorrentes daqueles com que se deparou a própria Música, como área, ao procurar encontrar seu lugar no meio acadêmico. E ainda ficou demonstrado, no decorrer de nosso trabalho, que, entre as várias subáreas musicais, Práticas Interpretativas é, sem dúvida, atualmente, a mais cercada por desafios, já que menos afeita aos padrões acadêmicos pré-estabelecidos.

Como mais apropriadamente nos mostra o segundo capítulo, esses desafios são devidos, em grande parte, à dificuldade de aliar teoria e prática. Essa é uma dificuldade presente em todos os campos do conhecimento e da atividade humana e que, no âmbito 
da Música, também se apresenta. No caso específico de Práticas Interpretativas, às dificuldades do pesquisador/instrumentista, em registrar o conhecimento gerado em sua prática, se somam as dificuldades do próprio meio acadêmico em absorver outras formas de produzir conhecimento que não sejam as já consagradas pelas áreas tradicionalmente tidas como "científicas".

O terceiro capítulo mostra, por outro lado, que, apesar do quadro traçado, os trabalhos de pesquisa voltados para Práticas Interpretativas começam a se avolumar, e vão buscando seus próprios caminhos, tanto em relação à forma de registro, como em relação ao processo de pesquisa.

Os trabalhos selecionados, constantes desse capítulo, revelam o esforço de adaptação aos parâmetros já estabelecidos, mas também o esforço de conciliação com as peculiaridades que carregam. Na grande maioria, partem de procedimentos já tradicionalmente estabelecidos pela Musicologia, como levantamento de dados históricos e biográficos. Em seguida, realizam uma análise do material musical. De posse desses dados, buscam sugerir decisões interpretativas. Esse formato apresentou-se constante na organização desses estudos, comportando-se como um formato razoavelmente delineado.

Mas, quando este formato não se revelou suficiente para a abordagem proposta, os trabalhos (e seus autores) procuraram estabelecer caminhos metodológicos mais apropriados a problemas que detectaram no fazer musical. Considerem-se essas perspectivas nas dissertações de Flávio Apro e Wladimir Farto Contesini de Mattos.

O primeiro parte de um questionamento estético-filosófico, decorrente do conflito entre duas posturas: imprimir à interpretação maior grau de fidelidade às intenções do compositor ou priorizar a liberdade criativa do intérprete. O segundo, igualmente, parte de uma dificuldade específica, isto é, como resolver, na interpretação, as tensões que se estabelecem entre texto verbal e texto musical, quanto aos aspectos rítmico-prosódicos. Busca um formato de análise baseado em teorias lingüísticas e musicais, e aponta possíveis soluções. De uma forma ou de outra, busca-se um caminho que atenda tanto às expectativas dos pesquisadores/intérpretes, quanto às exigências acadêmicas.

$\mathrm{Na}$ medida em que os trabalhos se avolumam, é de se esperar, como consequiência, que a identidade de Práticas Interpretativas se delineie com maior precisão e os programas se aprimorem, criando-se também um espaço mais definido para esse segmento, e essa é a impressão que os próprios docentes entrevistados 
manifestaram. Em decorrência disso, os futuros projetos de pesquisa irão encontrar campo mais apropriado para se formularem, pois encontrarão alicerces mais firmes e mesmo um terreno já mais pavimentado por um desenvolvimento contínuo da produção de conhecimento nessa área.

Outra questão relevante que abordamos em nosso terceiro capítulo é a relação entre análise e interpretação, assunto recorrente no meio musical. A negação absoluta da importância da análise tradicional não parece encontrar eco nos trabalhos e nas principais posições referidas. Entretanto, parece consenso que um outro tipo de análise, que leve em conta aspectos interpretativos mais do que quaisquer outros, deva erigir-se como referência para os trabalhos da subárea. Mas essa "análise interpretativa" não possui ainda uma feição clara, e suas premissas não estão definidas.

Ainda tem-se que avançar muito também sobre as questões que tratam das interpretações que não pretendem apoiar-se em fundamentos lógico-racionais reconhecidos, ou seja, que acreditam num conhecimento ou consciência formados a partir de outras premissas, mesmo que ainda não verbalizadas. Trata-se de aceitar que experiências não verbalizadas ou ainda não transferidas ao papel possam gerar interpretações convincentes, porque possuidoras de outra lógica, ainda não de todo inserida no meio acadêmico. E nesse contexto surge o questionamento: se o conhecimento gerado pelo processo analítico é o único capaz de pensar a interpretação ou não.

Para possibilitar uma reflexão sobre essa questão, debruçamo-nos sobre os escritos de Lester e Rothstein, estudiosos que ao assunto se dedicaram. Ao fim, propusemos que análise e interpretação possuem, cada uma, seu valor como objeto de estudo, valor que não depende da corroboração mútua das duas especialidades. Antes, o diálogo entre ambas, em condições de equilíbrio, é que pode elevá-las. A presença, nos trabalhos que compõem a amostragem desse terceiro capítulo, da análise e da interpretação correlacionadas, em maior ou menor grau, aponta para esse diálogo.

Outro dado relevante não pode deixar de figurar entre as considerações conclusivas. É o fato de um número significativo de pesquisas assimilarem, a seu próprio fazer, a matéria-prima das Práticas Interpretativas. $\mathrm{Na}$ amostragem de trabalhos selecionados, interpretações das obras tomadas como objeto de estudo compõem o produto final dos trabalhos, ou servem como ponto de partida para a pesquisa. É, pois, já, uma forma de incorporar a práxis interpretativa à produção do conhecimento. 
Constatamos, ainda, nos trabalhos analisados, a tendência ao estudo de obras que compõem o repertório da música brasileira, tendência que se estabeleceu logo que a Música passou a fazer parte do mundo acadêmico. Das nove dissertações, apenas uma foge a essa perspectiva.

Das entrevistas com os professores que já estiveram na coordenação dos programas de pós-graduação das três universidades estaduais paulistas, depreende-se um esforço das mesmas em aprimorar os programas. Todos apontam a atuação da CAPES como de real importância para esse aprimoramento, ao estabelecer as premissas para implantação dos cursos e acompanhar e avaliar o desempenho dos mesmos. Constatam dificuldades, mas relatam iniciativas e passos decisivos no sentido de superá-las. A leitura, na íntegra, da transcrição dessas entrevistas, pode fornecer perspectivas interessantes desses aspectos, bem como sobre as outras questões acerca das quais discorremos, uma vez que as perguntas formuladas procuraram captar de forma abrangente e ao mesmo tempo detalhada todos os ângulos do problema.

Este trabalho se propôs a traçar um perfil dos estudos em nível de mestrado e doutorado nos cursos de pós-graduação das universidades estaduais paulistas. Acreditamos ter atingido nosso objetivo e colaborado para que a discussão em torno do assunto frutifique. A existência mesma deste trabalho demonstra, a nosso ver, que a discussão caminha rumo ao amadurecimento. 


\section{REFERÊNCIAS BIBLIOGRÁFICAS}

ANPPOM Associação Nacional de Pesquisa e Pós-Graduação em Música. Disponível em http://www.anppom.com.br. Acesso em 19 ago.2009

APRO, Flávio. Os fundamentos da interpretação musical: aplicabilidade nos 12 Estudos para Violão de Francisco Mignone. São Paulo, 2004. Dissertação (Mestrado em Música) - Instituto de Artes, Universidade Estadual Paulista.

AQUINO, Felipe Avellar de. Práticas Interpretativas e a Pesquisa em Música: dilemas $e$ propostas. Revista Eletrônica da ANPPOM, Opus 9, 2003. Disponível em: http://www.anppom.com.br/opus/opus9/opus9-8.pdf. Acesso em 07 set. 2008.

BARK, Jamil Mamedio. Radamés Gnattali: - "Suíte para Quinteto de Sopros" Estudo Analítico e Interpretativo. São Paulo, 2007. Dissertação (Mestrado em Música) - Escola de Comunicações e Artes, Universidade de São Paulo

BARRENECHEA, Lúcia. Pesquisa no Brasil: Balanço e Perspectivas. Revista Eletrônica da ANPPOM, Opus 9, 2003. Disponível em: http://www.anppom.com.br/opus/opus9/opus9-9.pdf. Acesso em 07 set. 2008.

BORÉM, Fausto. Entre a Arte e a Ciência: reflexões sobre a pesquisa em performance musical. In: I SNPPM, 2000, Belo Horizonte. Anais... Belo Horizonte: Seminário Nacional de Pesquisa em Performance Musical, 2000, p. 142-148.

CAPES Coordenação de Aperfeiçoamento de Pessoal de Nível Superior. Critérios de Implantação Mestrado e Doutorado Acadêmico. Disponível em http://www.capes.gov.br. Acesso em: 21 ago. 2009

ECO, Umberto. Como se faz uma tese. Trad. Gilson Cesar Cardoso de Souza. São Paulo: Perspectiva, 1989. (Estudos)

GARDNER, Howard. Estruturas da mente: a teoria das inteligências múltiplas. Porto Alegre: Artes Médicas, 1994.

GERSCHFELD, Marcelo. Pesquisa em Práticas Interpretativas: situação atual. In: IX ENCONTRO ANUAL DA ANPPOM, 1996, Rio de Janeiro. Anais... Rio de Janeiro: Associação Nacional de Pesquisa e Pós-Graduação em Música, 1996, p. 60-66.

HARNONCOURT, Nikolaus. O Discurso dos Sons: Caminhos para uma nova compreensão musical. Trad. Marcelo Fagerlande. Rio de Janeiro: J. Zahar, 1998.

IAZZETTA, Fernando Henrique de Oliveira. Entrevista concedida a Cláudia Elena Siste. São Paulo, 2009.

KAYAMA, Adriana Giarola. Entrevista concedida por telefone a Cláudia Elena Siste. São Paulo, 2009. 
KERBER, Juliano Brito. As miniaturas musicais de Nilson Lombardi. São Paulo, 2007. Dissertação (Mestrado em Música) - Instituto de Artes, Universidade Estadual Paulista.

KERR, Dorotéa Machado. Entrevista concedida a Cláudia Elena Siste. São Paulo, 2009.

KUBALA, Ricardo Lobo. A escrita para viola nas Sonatas com piano op. $11 n^{\circ} 4$ e op. $25 n^{\circ} 4$ de Paul Hindemith: aspectos idiomáticos, estilísticos e interpretativos. Campinas, 2004. Dissertação (Mestrado em Música) - Instituto de Artes, Universidade Estadual de Campinas.

LESSA, Angélica Giovanini Micheletti. Missa Ferial de Osvaldo Lacerda - Uma Análise Interpretativa. São Paulo, 2007. Dissertação (Mestrado em Musicologia) Escola de Comunicações e Artes, Universidade de São Paulo.

LESTER, Joel. Performance and analysis: interaction and interpretation. In: RINK, John. The Practice of Performance: Studies in Musical Interpretation. Cambridge: Cambridge University Press, 1995, p. 197-216.

LIMA, Sonia Albano de. Pesquisa e Performance. In: XIII ENCONTRO NACIONAL DA ANPPOM, 2001, Belo Horizonte. Anais... Belo Horizonte: Associação Nacional de Pesquisa e Pós-Graduação em Música, 2001. v. 2, p.531-538.

MAESHIRO, Midori. Questões estruturais e interpretativas na obra pianística de Ricardo Tacuchian. Campinas, 2007. Tese (Doutorado em Música) - Instituto de Artes, Universidade Estadual de Campinas.

MATTOS, Wladimir Farto Contesini de. Análise rítmico-prosódica como ferramenta para a performance da canção: um estudo sobre as canções de câmara de Claudio Santoro e Vinícius de Moraes. São Paulo, 2006. Dissertação (Mestrado em Música) Instituto de Artes, Universidade Estadual Paulista.

NOGUEIRA, Ilza. Seminário de Avaliação da Área de Música: Um Esforço pela Efetividade e Otimização do Fomento à Música. In: IX ENCONTRO ANUAL DA ANPPOM, 1996, Rio de Janeiro. Anais... Rio de Janeiro: Associação Nacional de Pesquisa e Pós-Graduação em Música, 1996, p. 39-44.

PINOTTI, Cíntia Maria Annichino. O Salmo 150 de Ernst Mahle - questões composicionais e interpretativas. São Paulo, 2002. Dissertação (Mestrado em Musicologia) - Escola de Comunicações e Artes, Universidade de São Paulo.

RODRIGUES, André Figueiredo. Como elaborar citações e notas de rodapé. $3^{\mathrm{a}}$ ed. amp. São Paulo: Humanitas/FFLCH/USP, 2005. (Metodologias, v. 2)

Como elaborar referência bibliográfica. $2^{\mathrm{a}}$ ed. rev. São Paulo: Humanitas/FFLCH/USP, 2004.

ROTHSTEIN, William. Analysis and the act of performance. In: RINK, John. The Practice of Performance: Studies in Musical Interpretation. Cambridge: Cambridge University Press, 1995, p. 217-240. 
UFMG Universidade Federal de Minas Gerais. PerMusi - Revista Acadêmica de Música. Disponível em: http://www.musica.ufmg.br/permusi. Acesso em: 19 ago. 2009

UFRGS Universidade Federal do Rio Grande do Sul - Programa de Pós-Graduação em Música. Disponível em: http://www6.ufrgs.br/ppgmusica. Acesso em: 15 ago. 2009

UNESP Universidade Estadual Paulista. Programa de Pós-Graduação em Música Stricto Sensu, Apresentação do Programa. Disponível em http://www.ia.unesp.br. Acesso em: 15 ago. 2009.

UNICAMP Universidade Estadual de Campinas. Programa de Pós-Graduação em Música. Disponível em http://www.iar.unicamp.br. Acesso em: 19 ago. 2009.

USP Universidade de São Paulo. Programa de Pós-Graduação em Música, Estrutura do Programa. Disponível em http://poseca.incubadora.fapesp.br. Acesso em: 19 ago. 2009.

YANSEN, Carlos Alberto Silva. Almeida Prado: estudos para piano, aspectos técnicointerpretativos. Campinas, 2005. Dissertação (Mestrado em Música)- Instituto de Artes, Universidade Estadual de Campinas. 
ANEXOS 


\begin{abstract}
ANEXO I
Entrevista com a Professora Doutora Dorotéa Machado Kerr, realizada no dia 11 de agosto de 2009, em São Paulo (transcrição literal).
\end{abstract}

\title{
Cláudia Elena Siste
}

1) Como começou o Programa de Pós-Graduação em Música da UNESP? Quais os principais professores que atuaram no início?

\section{Dorotéa Machado Kerr}

Olha, o início, verdadeiramente, eu não vou poder ser muito precisa com você, talvez você tivesse que... nem sei se tem atas de reunião lá para você ver. Porque foi criado, talvez, eu acho que foi em 91, foi o Professor Régis Duprat e a Professora Neide Marcondes, era Artes. Então você teria que verificar lá nos documentos deles, porque eu cheguei lá em 94, então eu não sei de todos, e a outra pessoa que estava lá no começo foi a Professora Sekeff, que faleceu. Sou das reminiscentes, mas eu não estou desde o início, ela estava desde o início. Mas seguramente o Professor Régis foi importante, foi o mentor da criação toda, a Professora Sekeff foi muito importante. E depois acontece essa separação, que é determinada pela Capes, que se faça mesmo em 2001, que então separem os dois programas. Aí outros professores vieram se agregando no meio do caminho, a Professora Marisa Fonterrada veio, eu já estava antes, Professora Sekeff era mais antiga, outros saíram. Isso daí, acho que só com uma consulta, em termos de atas dos conselhos, para você verificar, se isso for muito necessário, verificar esses professores que atuaram.

\section{C.E.S.}

2) Que premissas foram apresentadas à Universidade para a criação do Programa?

\section{D.M.K.}

Eu também não posso dizer isso pra você no início, não sei como é que isso surgiu lá dentro da UNESP, porque quando eu entrei no processo, entrei primeiro como professora, essas coisas não eram muito discutidas. O Professor Régis Duprat é quem 
tinha mais o domínio disso, a Professora Neide, e, além do que, era em Artes. Era mais ou menos equilibrado entre as duas áreas e então não era muito discutido. Isso passou a ser um pouco mais discutido depois mesmo de 2001, mas por causa de dois eventos que aconteceram: o fato de que nós tivemos nota baixa. Naquela ocasião, várias tiveram, e nós tivemos duas vezes a nota três, e a nota três significava que... agora significa praticamente que o curso pode se extinguir, pelo menos na visão atual, mas na época não, foi dada uma oportunidade. Na segunda vez teve um plano de recuperação, que também foi cortado, então foi mesmo a partir daí, dos anos 99, 2000, 2001 que se começou discutir um pouco melhor. Mas não vem assim como uma diretriz, uma coisa assim "vocês têm que fazer isso", não é, não é assim que funciona. Depende muito do corpo docente trabalhar de forma integrada, ter uma boa Pró-Reitoria de Pós-Graduação que possa passar informações, ir às reuniões e perceber o que está acontecendo, é mais ou menos assim. Não é uma coisa escrita com tanta clareza, nesses anos para trás. Depois, agora, nos últimos anos, as coisas têm ficado bem mais claras mesmo. A PróReitoria anterior e a que nós temos agora é muito atuante, a anterior e a atual são muito atuantes, então o Coordenador e o corpo docente se sentem um pouco mais seguros, parece que tem bastante fundamento, mas no início não era não.

\section{C.E.S.}

3) Quais as Áreas de Concentração e Linhas de Pesquisa predominantes desde a criação do Programa?

\section{D.M.K.}

Ali, por serem Artes, eu não vou poder responder também tudo, seria bom você olhar na ata de criação. Mas seguramente a linha mais predominante ali na UNESP foi a Musicologia. A linha de Performance não havia, e, se havia no papel, ela não havia na prática. Ela não acontecia. Não era das idéias do Professor Régis Duprat que a linha tinha [tivesse] condições de andar sozinha ali. Então, não existia. E não sei também dizer se a linha de Teoria era contemplada. Depois da separação sim, aí nós separamos, ficou bem claro, com as Áreas de Concentração, ficou Musicologia, ficou Educação Musical, as áreas mais estabelecidas, digamos assim, Teoria e Performance (Práticas Interpretativas, que demos o [esse] nome). E aí nós resolvemos juntar, porque isso tudo também depende não é só da vontade, você depende do corpo docente que tem. Você não pode ter uma Linha de Pesquisa ou uma Área de Concentração com pouca gente. 
Então, na verdade, Educação Musical sempre foi um grande chamariz no IA, chamariz para aluno, mas sempre teve pouco professor. Então nunca pode ficar absolutamente sozinho. Então tem que se compor com outros e estar junto com a Musicologia, por exemplo. Então tem coisas que não são só da área do pensamento, do que a gente pensaria que deveria ser assim, são coisas de caráter prático, porque que não pode funcionar o Programa sem às vezes haver o mínimo de professores. E nós sempre tivemos assim um mínimo, estávamos sempre perto do mínimo, parece que são nove professores e nos estávamos entre dez e onze. Então qualquer um que saísse fazia muita diferença no Programa. E aí desorganizava mais ou menos as áreas.

\section{C.E.S.}

4) Quais as principais transformações que o Programa sofreu desde a sua implantação?

\section{D.M.K.}

Exatamente. Em primeiro lugar foi essa questão das notas, quando começaram a valer as notas. Nós sabíamos que haveria um sistema de avaliação, acho que começou em 96, 97, por aí, mas o sistema foi ficando aprimorado. Essa foi uma enorme mudança. Porque a avaliação externa da Capes pressionou bastante. Ela é muito exigente, e com a exigência ela quase que dá uma linha condutora de como o Programa tem que se comportar. Eu diria até que ela quase que cria uma filosofia do que tem que ser, e quanto menos [mais] a gente vai demorando para se adequar a isso mais danos traz para o Programa. Um pouco aconteceu isso com a UNESP. E depois a gente conseguiu arrumar a casa, arrumar o Programa, isso então aconteceu, e nós recebemos a nota quatro, então foi a grande mudança, foi essa. E daí a possibilidade de, com a nota quatro, criar o doutorado.

\section{C.E.S.}

5) Como a Senhora considera o desenvolvimento do Programa no que diz respeito à qualidade e quantidade das pesquisas realizadas?

\section{D.M.K.}

Olha, da quantidade nos temos mais de cem, eu sabia o número certo, mas agora não tenho isso na cabeça mais. Mas, mesmo nesse período em que nós ficamos com a nota baixa, nós não paramos de trabalhar. Porque outras universidades deixaram de existir, 
fecharam, os programas desistiram, mas nós continuamos firmes. E continuamos produzindo. Então o número da produção eu considero assim que é razoável, eu diria assim que há uma média de uns 10 a 15 por ano. Quando você faz uma contagem mais ou menos você vai ter uma idéia do que dá neste tempo todo. A qualidade é bastante diversificada, muito diversificada. Em função mesmo de uma própria turma que entra, às vezes bastante imatura para o trabalho, não consegue perceber como fazê-lo; outras também em razão dos próprios orientadores, mudanças de orientadores que acontecem, isso tudo dificulta bastante o trabalho do aluno. Então, eu diria que a qualidade é diversificada.

\section{C.E.S.}

6) Qual a importância que a Pesquisa em Práticas Interpretativas ocupa atualmente no Programa de Pós-Graduação da UNESP?

\section{D.M.K.}

Ele é importante como as outras, é uma linha importante como todas as outras, nós tentamos não fazer diferença nenhuma, desde que foi implantada e que tem professores que assumiram. Mas ela não floresceu talvez na medida em que eu, particularmente, como coordenadora, na época, gostaria. E ainda hoje, mesmo como professora. Então, ela não tem diferença, ninguém trata diferenciadamente, mas ela não tem o mesmo florescimento. A nossa busca, por exemplo, no Instituto de Artes, quando se abre processo seletivo, a busca [procura] muito grande é para Educação Musical. Porque talvez seja uma área que dá margem para a pessoa trabalhar com mais facilidade em centros culturais, até na vida acadêmica, e em muitas outras coisas, não fica tão [r] estrito. Então essa sempre tem sido a linha mais procurada, não linha, porque ela não está sozinha, mas, de qualquer forma, nós não fazemos diferença, nenhuma é mais importante aos nossos olhos.

\section{C.E.S.}

7) De que maneira as pesquisas em Práticas Interpretativas relacionam-se com as Áreas de Concentração e as Linhas de Pesquisa atuais? 


\section{D.M.K.}

Eu não sei dizer exatamente isso também. Eu acho que as coisas ainda são muito fragmentadas, elas precisariam ser mais unidas e repensadas em conjunto. Então não tenho uma resposta para essa pergunta.

\section{C.E.S.}

8) Como a Senhora considera que pesquisas em Práticas Interpretativas influenciam verdadeiramente na Performance?

\section{D.M.K.}

É um assunto que eu acho que é bastante candente, porque os intérpretes, quando vão para a academia, utilizam essa justificativa, de que a análise é importante para sua execução musical. Eu lembro até de uma história de um grande pianista, alguém perguntou isso para ele, e ele falou "eu não faço análise nenhuma, não tenho nada que fazer isso, imagina, eu toco, eu toco". E é um fantástico pianista, um dos mais prestigiados do Brasil. Eu me lembro dessa resposta e achei muito interessante. Então nem acho que para todos os músicos isso é claro. Eu acho que a academia precisa definir isso com uma certa urgência. Porque da mesma forma que qualquer pesquisa precisa ter uma pergunta, porque pesquisa só pode ser gerada diante de um problema, a performance precisa ter um problema para precisar ser respondido. E da mesma forma a análise musical, não basta você sentar e querer decompor a música, e perceber aí que se faz uma análise harmônica, depois faz uma melódica e não sei o quê, e como que você liga isso depois com a performance? Então acho que precisa é de uma pergunta, uma pergunta básica que eu acho que é muito difícil de formular, e às vezes os pesquisadores ainda não estão habilitados a essa formulação da pergunta. Então acho que aí falha. Eu não saberia responder também como fazer essa ligação ainda de uma forma muito clara. Eu só acho que deve existir uma ligação, é um desafio, é um desafio intelectual para nós descobrirmos, e precisa ser estudado sim.

\section{C.E.S.}

9) Há um formato recorrente perceptível nas pesquisas que tratam das Práticas Interpretativas na UNESP? 


\section{D.M.K.}

Na UNESP eu não diria que tem tanto um formato assim porque nós nem temos tantas [dissertações] em Práticas Interpretativas, como eu já lhe disse, não fazia parte do corpo no início. E mesmo depois, quando ela veio, ela não veio assim com uma forma muito clara. Então eu acho que a UNESP não tem esse formato, não tem aquele formato assim, pelo menos a gente tenta evitar aquele formato muito claro, entre biografia e a obra analisada, onde nada se coaduna, um não liga com o outro. A biografia é uma coisa, a obra analisada é outra, e se o aluno fizer o recital ou não fizer tanto faz também. Isso eu tenho visto, não só na UNESP, mas em outros lugares. Na UNESP menos, porque, como falei para você, nós não insistimos muito nesse tipo de formato. Tanto que os que surgiram, surgiram em função de diferentes propostas e talvez assim até formas meio desafiadoras da gente enfrentar esse problema. Porque acho que ninguém na UNESP acredita nesse formato assim padronizado.

\section{C.E.S.}

10) Que importância a Senhora atribui à análise como ferramenta que ampara a interpretação?

\section{D.M.K.}

Então, eu acho que isso é um grande desafio, desde que você tenha uma pergunta para a análise. Para quê? Por que eu preciso descobrir isso? O que é que eu preciso descobrir? E o que é que isto daqui vai afetar a minha interpretação? Que problema na minha interpretação exige que eu precise fazer uma análise? Acho que a passagem de uma para a outra não é simples. Ela não é, digamos, "natural”. E, como qualquer pesquisa, reitero, ela precisa de perguntas. Então acho que o pesquisador e o aluno precisam aprender a fazer perguntas em primeiro lugar.

\section{C.E.S.}

11) Como é visto pela Senhora o fato de que instrumentistas, tanto professores quanto alunos, quando ligados à universidade, tenham que, de alguma maneira, relacionar sua interpretação às práticas acadêmicas? 


\section{D.M.K.}

Porque isso é uma exigência legal. Entrou na universidade, a universidade é um outro campo, ela é um outro mundo, ela é o mundo do conhecimento e principalmente é o mundo da produção do conhecimento. Muitos se queixam que às vezes o ensino não é tão valorizado, ele não é valorizado porque se o ensino não é simplesmente, às vezes, a reprodução de conhecimentos do passado, que às vezes é muito o que acontece, desse ponto de vista ele não é válido mesmo. O ambiente universitário exige realização de produção de conhecimento. E isso é muito difícil na música ou nas artes, no meu entender. Na performance, praticamente, isso é mais difícil ainda, porque a performance exige outras coisas, outras habilidades. Então é uma coisa também que não ainda está muito bem resolvida, desde que as universidades decidiram que teriam seus cursos de artes e de música dentro delas. Elas ainda sofrem com isso. È uma área que ainda traz conflito, traz desagrado, traumas, stress entre as pessoas, entre o professor e o que chamamos burocracia, quer dizer, o que está do outro lado: "Ah, não reconhece que eu fiz um $\mathrm{CD}$, ah, não reconhece que eu fiz isso...”. Realmente, a universidade reconhece outras coisas, é o papel dela reconhecer outras coisas, essa produção, que no caso do conhecimento ainda é feito muito via escrita, pela forma comunicativa da língua. E não dessa chamada (ou não agora mais tão chamada!) linguagem musical. Então acho que ainda também é um outro desafio a ser vencido.

\section{C.E.S.}

12) Que papel ocupa o Programa de Pós-Graduação da UNESP em relação às outras universidades estaduais paulistas? Há um perfil específico?

\section{D.M.K.}

Eu não diria que nenhuma [alguma] tem. Nenhuma tem um perfil específico, exatamente porque eu entendo que, como todos os professores ainda trabalham de uma forma muito esparsa e isolada, e fragmentada, não se criou verdadeiramente um nicho, nichos, assim, importantes. Então nenhuma delas me parece que tem um perfil. Quando eu olho, quando eu vejo meus colegas, os trabalhos dos meus colegas, eu não sinto isso. Eu não diria assim: "Olha, se eu quero estudar análise musical eu vou para não sei aonde, ou vou pegar tal professor”. Porque não há essa linha de continuidade, a fragmentação é muito grande. Então acho que ainda falta a definição de um perfil. A busca do perfil é uma das buscas importantes [a] que a Capes nos obriga. Ela exige até 
que isso seja tratado dentro da avaliação. Mas ainda, do meu ponto de vista, ainda está difícil de ser visualizado.

\section{C.E.S.}

13) Quais os principais desafios a serem ainda enfrentados pelo Programa de PósGraduação em Música da UNESP?

\section{D.M.K.}

É isso, a criação de um perfil, com linhas bem delineadas, claras, com trabalhos que não sejam fragmentados em diversos assuntos, trabalhos de boa qualidade. Eu acho que o desafio é completo, porque, mesmo que você atinja um certo nível, você vai perceber outros que você deveria melhorar. Então, não vai parar nunca, eu acho que esses sempre são problemas que devem ser resolvidos e devem ser elementos aprimorados. Estabelecer o perfil, ter novas linhas, perceber a sociedade, perceber o que precisaria ter agora, que outras disciplinas oferecer, que outras linhas de pesquisa criar. Isto teria que estar em constante contato com isso, é um aprimoramento contínuo.

\section{C.E.S.}

14) Qual é a avaliação geral que a Senhora faz do Programa desde a sua criação até os dias de hoje?

\section{D.M.K.}

Eu faço uma boa avaliação. Eu acho que os professores foram muito dedicados, porque o fato de termos tido duas notas baixas nos deixou bastante, assim, abalados, num certo sentido, e isso causa um certo desprestígio, até pessoalmente para o professor. O professor não é mais convidado para comissões externas, não participa talvez de congressos, não está entre os organizadores de congressos, e tudo isso faz parte da vida acadêmica, entre outras coisas. E eu acho que o grupo de professores do Instituto de Artes soube vencer isso muito bem. Acho que forçou, ficou, foi um tempo difícil e o tempo ficou difícil também pelo seguinte, porque a nota baixa representou corte de dinheiro, a Capes então não repassava mais dinheiro. O Programa não tinha dinheiro nenhum! E isso desistiu [perdurou]. Por dois, três triênios, eu acho, assim de uma forma que acho até admirável. Eu respeito muito os professores todos que ficaram juntos nesse 
barco, fechados ali, mesmo com esses problemas que eu reconheço de fragmentação, mas eu acho que houve assim um esforço conjunto muito grande, que eu acho muito meritório.

\section{C.E.S.}

15) Que outras informações a Senhora gostaria de acrescentar?

\section{D.M.K.}

Eu gostaria de acrescentar que acho que os Programas de Pós-Graduação no Brasil, em Artes, em Música, eles são novos, mas já trouxeram benefícios. Você vê já um volume grande de produção, embora possamos fazer todas as críticas que eu já mencionei, acho que isso é importante. A existência, já existe uma massa crítica de trabalhos, daqui para a frente vai se começar a prestar atenção melhor no que fazer, porque tem um ou outro que não foi tão bom. Acho que isso é muito positivo, e vejo também que, da mesma forma que eu via na UNESP esse esforço conjunto para sair da situação, os outros programas também. Quer dizer, foi um esforço nacional, de criar muita coisa. Eu acho que foi muito positivo. Os congressos têm sido positivos, as dissertações que saem, as publicações, os livros, nós agora já estamos entrando nas editoras universitárias e até não universitárias, temos várias revistas. Eu acho que deu um incremento muito grande, ele pode ainda não estar chegando lá na ponta, que é o aluno de graduação, porque parece também que essa ponte fica meio bloqueada. Mas não é por falta de conhecimento, de haver esse conhecimento, assim, bastante espalhado, que o aluno de graduação não vai poder usufruir. Ele não usufrui porque ele não sabe, porque ele não quer, ou porque ele não é levado a conhecer, porque para ele é que seria isso, não é? Melhorar todas as condições do conhecimento dele. Então eu acho que essa ponte está faltando, mas, no Brasil inteiro eu sinto que foi um esforço gigantesco e muito meritório também, da mesma maneira que eu respondi à outra pergunta.

\section{C.E.S.}

Muito obrigada pela entrevista.

\section{D.M.K.}

De nada. 


\begin{abstract}
ANEXO II
Entrevista com o Professor Doutor Fernando Henrique de Oliveira Iazzetta, realizada no dia 12 de agosto de 2009, em São Paulo (transcrição literal).
\end{abstract}

\title{
Cláudia Elena Siste
}

1) Como começou o Programa de Pós-Graduação em Música da USP? Quais os principais professores que atuaram no início?

\section{Fernando Henrique de Oliveira Iazzetta}

Bom, como já te falei, a história antiga do Programa não é muito bem contada e a gente não tem muita documentação. Mas ele nasce dentro de um Programa de Artes, começou como um grande Programa de Artes, que abarcava as três áreas, artes plásticas, cênicas e música, provavelmente por iniciativa das artes plásticas e das artes cênicas, e a música foi meio a reboque dessa iniciativa. Isso em 72 , se não me falha a memória. E é, na verdade, o Programa na área de Artes mais antigo do Brasil. Começou com mestrado, e já nesta época existiam algumas teses [dissertações], na área de música, poucas, bem pontuais, orientadas ou por professores da ECA, da Comunicação, ou eventualmente por professores aqui da casa [CMU]. Os professores envolvidos nesse momento eram o professor Olivier Toni, mais tarde o professor Amílcar, e depois foram chegando outros professores doutores que foram entrando. Mas, basicamente, neste início, era o professor Toni, e talvez mais algum, talvez o Fernando Crespo que já nem é mais professor da casa. Mas, enfim, circulava em torno do Toni. Em 91 foi criada de fato a área Musicologia, e daí passou a existir regularmente. Porque precisa entender uma coisa, que antes desse período, a própria organização da Pós-Graduação no Brasil não era tão regulamentada e regulada como é hoje, pela Capes e pela própria Universidade. Existia mais flexibilidade, mais informalidade na constituição dos Programas, etc. Com relação a Linhas de Pesquisa, Áreas de Concentração, tudo isso era muito mais flexível do que é hoje. Então a partir daí é que começa a ter um Programa, com os professores da casa, o Marcos Lacerda, o Marco Antonio da Silva Ramos, o próprio Toni. Não saberia dizer qual era a lista completa, mas eram os professores que naquele momento tinham o título de Doutor, que não eram muitos. Daí é que começa a ter uma produção 
regular de dissertações. Professor José Eduardo Gandra Martins também já estava nesse grupo, e o professor Mário Ficarelli também. Até 2000, mais ou menos, existia uma produção pequena, o programa continuava chamando-se Programa de Pós-Graduação em Artes, com três Áreas de Concentração, uma delas era Musicologia, que era onde ficavam as dissertações de mestrado de música, e aos poucos esses programas foram... essas três áreas foram ganhando autonomia. Elas estavam dentro do mesmo Programa, mas funcionavam de maneira independente, tinham grupos independentes de professores, de disciplinas, etc. A partir de 2000, um pouco porque a própria Capes começou a apertar mais o cerco na regulamentação dos Programas, houve um esforço maior de organização da Pós-Graduação. A própria regulamentação dos Programas começou a ser feita com mais cuidado e ser, vamos dizer, efetivamente aplicada, coisa que não acontecia antes. E daí há um crescimento progressivo, constante, bastante grande do Programa, eu não vou saber te dizer as datas, depois eu posso te passar, mas, por volta de 2004, apenas a área de Musicologia não tinha doutorado, por razões políticas até. Os professores achavam que não devia haver doutorado em Música e impediram que isso acontecesse, mas não era por falta de condições de ter. Então a gente, daí nessa época eu já estava na Coordenação do Programa, a gente fez o projeto para que abrisse o nível de doutorado também na área de Musicologia. E em 2006, mais ou menos, a gente entrou com o processo para a separação dos três cursos, das três áreas que se tornaram três cursos independentes, e a área de Musicologia passou então a se chamar Programa de Pós-Graduação em Música. A aprovação, se não me engano, é do início de 2007, é quando entra em funcionamento oficialmente, tanto na USP como na Capes, o novo Programa de Música, que herda tanto os alunos como o corpo docente e uma parte da estrutura da antiga área de Musicologia do Programa de Artes e se torna um Programa independente.

\section{C.E.S.}

2) Que premissas foram apresentadas à Universidade para a criação do Programa?

\section{F.H.O.I.}

Do Programa de Artes eu não sei, me parece um caminho um pouco natural, porque é uma grande universidade, a Área de Artes na década de 70 começa a ter uma certa consistência, tem grandes nomes entre os professores, então me parece natural que se criasse um Programa de Pós-Graduação em Artes e acho que até com, posso estar 
errado porque eu não estava nesse momento, talvez até com incentivo da Universidade, da Pró-Reitoria de Pós-Graduação. Na época da separação das três áreas, e a criação dos três programas independentes, o quadro já era bem diferente. A Universidade tem uma preocupação muito grande em manter as notas dos programas e o nível dos programas bem altos; o número de programas é muito grande, então tem uma preocupação em manter esse número, não digo reduzido, mas enxuto, pelo menos. Então não há um incentivo da Universidade para que se criem novos programas, muito pelo contrário, às vezes há até incentivo para que se... quando dois programas não têm uma produção muito grande, ou quando não têm infra-estrutura muito grande, que eles se fundam e formem um programa maior, com mais possibilidades. Então quando a gente apresentou essa proposta de subdivisão em três novos programas, a gente teve que realmente fazer uma justificativa muito grande para demonstrar que não havia sentido em manter os três programas juntos, porque já eram três estruturas autônomas, que já existia um corpo, uma massa crítica, um corpo docente, uma produção passada nas três áreas, individualmente, que justificava a separação. E então uma grande parte do projeto é de justificativa da criação. De fato, a justificativa era muito contundente, e a Reitoria aceitou com pouquíssimas ressalvas.

\section{C.E.S.}

3) Quais as Áreas de Concentração e Linhas de Pesquisa predominantes desde a criação do Programa?

\section{F.H.O.I.}

A inclinação maior sempre foi Musicologia aqui, o que não quer dizer muita coisa. Mas em boa parte, existia um grande número de pesquisas que a gente poderia chamar de Musicologia Histórica, especialmente de música brasileira. Isso foi sempre uma tendência grande no programa, que talvez tenha até diminuído um pouco nos últimos anos, mas anteriormente era. Alguns poucos trabalhos de análise, mais focada na análise instrumental, análise de obras ou de repertório específico, e alguns poucos trabalhos na área de Educação. Mas não dá para dizer, assim, que o Programa tivesse uma característica muito específica. Dá para dizer o tipo de trabalho que não costumava existir. Não costumavam existir trabalhos muito voltados para a prática, performance e composição, especialmente porque isso não fazia parte do perfil dos Programas de PósGraduação de Música em geral, os trabalhos de Educação eram poucos porque não 
existiam orientadores nessa área, então os trabalhos acabavam sempre dominantemente na área de História da Música, um pouco de análise misturada com história, e alguns trabalhos um pouco mais reflexivos: crítica, teoria, e tal. Esses eram um pouco menos numerosos. Hoje acho que já tem uma expansão maior, a área de Musicologia é dominante ainda, mas o corpo de professores cresceu muito e ele é diverso. Então já tem vários trabalhos na área de Práticas Interpretativas, alguns trabalhos, por exemplo, nas áreas que eu atuo, de música e tecnologia. Talvez as áreas ainda um pouco tímidas seriam composição, especialmente composição, regência, e educação musical que até hoje são poucos trabalhos ainda que são realizados.

\section{C.E.S.}

4) Quais as principais transformações que o Programa sofreu desde a sua implantação?

\section{F.H.O.I.}

Acho que dá para pegar uns três ou quatro períodos para ser bem resumido. Tem esse início, década de 70 a 80, que é uma coisa informal, com pouquíssimos trabalhos, um ou dois orientandos ali, uma coisa muito esporádica. Depois tem a implantação do programa propriamente dito, aí começa a ter uma regularidade, tem um grupo fechado de professores, cinco ou seis professores, talvez um número de seis a oito professores, que são do Departamento de Música, oferecendo regularmente disciplinas de música, com alunos que se inscrevem para essa área e tal, então começa a ter uma regularidade de produção de dissertações. Isso iria até final dos anos 90. Tem no início... final dos anos 90 e começo de 2000 tem uma tentativa de organização dos programas, de regulamentação do funcionamento, etc., um cuidado maior com os processos de seleção, que ficam mais formais, enfim, uma série de cuidados que vão reverter na melhoria do programa. Isso tem a ver com uma vontade própria do programa, mas também com uma cobrança da Universidade e especialmente da Capes. E eu acho que lá para 2005, para frente, tem uma outra fase, que é justamente já ter o doutorado implementado, isso modifica muito. Aí sim acho que tem uma mudança muito grande. Primeiro tem o doutorado implementado que modifica o perfil do aluno. Quase... não chega a ser metade, mas um grande número dos alunos são de doutorado. O número de alunos cresce muito, o número de professores salta desses seis, oito, nove, vai para quinze, dezesseis. Hoje, até o final deste ano, o Rogério pode te dar este número, mas deve chegar a vinte ou até mais de vinte professores. Existe uma oferta de disciplinas muito 
grande, existe uma renovação do quadro docente, muitos desses professores são novos, e isso também traz uma diferença muito grande para o programa. Os primeiros professores, eles fizeram as suas pós-graduações, tiraram seus títulos num outro contexto, em que tanto a pesquisa quanto a pesquisa em música ainda eram um pouco indefinidas. Essa nova leva de professores que vem a partir de 2000 e pouco, eles já fazem parte de professores que se doutoraram num esquema muito mais formal, muito mais rígido, inclusive em termos de pesquisa acadêmica. E num ambiente onde já se sabe mais ou menos o que é pesquisa acadêmica em música, etc. Então eles vêm já com uma nova visão do que é a pós-graduação, etc., isso também eu acho que permitiu um grande salto para o programa. E depois a própria... aí são duas coisas que acontecem mais ou menos juntas, uma é a emancipação dos três programas, a subdivisão do programa de artes em três programas, que dá mais autonomia ao programa de música, na sua reestruturação, e o próprio projeto desse programa faz com que a antiga área de Musicologia tenha que ser repensada; e a mudança do regimento da pós-graduação pela Pró-Reitoria de Pós-Graduação, que é de... o processo começou em 2006, mais ou menos, e que foi aprovado acho que ano passado, e que dentro desse processo enxuga um pouco mais a estrutura da pós-graduação, deixa ela mais clara, mais inteligível, com um regimento bem mais claro. E acho que isso facilita com que ele seja seguido de fato. E o regimento tira a centralização da gerência dos programas das comissões de pósgraduação e dá mais autonomia para o programa em si. Então isso dá mais dinamismo para o programa detectar um problema na sua estrutura ou na sua estrutura de Linhas de Pesquisa, e rapidamente conseguir modificar e se adaptar a uma realidade nova, coisa que antigamente era muito difícil.

\section{C.E.S.}

5) Como o Senhor considera o desenvolvimento do Programa no que diz respeito à qualidade e quantidade das pesquisas realizadas?

\section{F.H.O.I.}

Eu acho que segue esse processo que eu te falei, a partir de meados dessa década de 2000; 2004 e 2005, tem uma mudança clara nesse processo. Não que a produção anterior... deixe-me pensar... A produção anterior me parece de muito bom nível, dentro panorama brasileiro, se você considera as dissertações e teses. Mas a produção docente, ela é boa enquanto produção artística, mas é muito deficiente enquanto produção 
científica. Isso não é privilégio desse programa, mas é algo que acontecia com todos os programas na área de artes. É nessa época também que os programas no Brasil inteiro começam a tentar mudar esse panorama. Então o programa hoje, ele tem uma produção, dentro do padrão nacional, bastante boa, tanto artística, que sempre teve, quanto científica, embora ainda na área de artes esse seja um problema a ser discutido, vamos dizer assim. Tem gente que acha que deveria ser artística, tem gente que acha que não, que na pós-graduação existe um trabalho de pesquisa voltado à questão acadêmica e científica e essa produção, mesmo que artística, tem que contemplar alguns quesitos que não são só estéticos, vamos dizer assim. E que não sejam só mercadológicos e de visibilidade, coisas desse tipo. Ainda é uma questão a ser discutida. Mas, nesse momento, existe uma mudança grande, talvez até um rigor maior nos projetos, na seleção dos projetos dos alunos que entram [no programa de pós-graduação], na qualidade desses projetos; e também, por parte dos professores, um esforço maior de ter uma produção acadêmica mais consistente, o que tem acontecido gradualmente.

\section{C.E.S.}

6) Qual a importância que a Pesquisa em Práticas Interpretativas ocupa atualmente no Programa de Pós-Graduação da USP?

\section{F.H.O.I.}

Eu acho que, na verdade, essa é uma grande deficiência do programa. Ele tem um quadro de professores (eu não saberia dizer agora, mas em algum momento, talvez por volta de 2003, 2004, 2005 ou 2006), talvez metade dos professores do programa, ou mais da metade dos professores do programa pertenciam à área de práticas interpretativas, pelo menos na sua atividade cotidiana. Mas, na pós-graduação, eles trabalhavam muito mais, por exemplo, com Musicologia. Mesmo não sendo essa a sua área principal de atuação e de formação. Então, hoje este quadro talvez tenha mudado um pouco e tal, mas a relação entre o número de professores de musicologia e de práticas interpretativas talvez tenha mudado, as áreas são mais diversas, mas isso acontece ainda de alguma maneira. Não há, primeiro, uma formalização da área, não há uma formalização que acho que seria necessária para distinguir o que é peculiar dessa área, que diferencia essa área de outras, e acho que dentro dessa própria área existe um problema que nunca foi discutido, de fato, aqui dentro, pelo menos a discussão nunca avançou suficientemente para trazer alguma solução, que é o fato de que você, dentro da 
área de práticas, pode ter várias perspectivas, várias direções. Você pode ter, por exemplo, um programa de pós-graduação voltado para performance, um modelo que muita gente associa ao modelo norte-americano, por exemplo, que você pode fazer disciplinas ligadas à sua prática instrumental, concluir alguns recitais, etc., e isso te daria um título. Especialmente para o mestrado, que o doutorado, geralmente, se exige uma contrapartida na forma de uma tese ou um trabalho, uma monografia estendida, uma coisa assim. Ou você pode ter uma pesquisa teórica, que te sirva, crítica ou analítica, de práticas interpretativas. E entre esses dois lados eventualmente existem outros caminhos que podem ser seguidos, até intermediários. Então, mesmo essa questão nunca foi, de fato, pensada aqui dentro. Cada professor, em função de cada aluno específico que ele recebe, ele acaba direcionando aquela pesquisa específica para um lado ou para outro, mas é uma coisa quase acidental. Depende da vocação do professor, do interesse dele naquele momento e da coincidência de ter um aluno com esse ou aquele perfil. Então, essas pesquisas de práticas, elas acabam aparecendo informalmente também, o que acontece um lado negativo, porque a gente já tem número suficiente de pessoas interessadas... a gente já tem demanda suficiente de alunos nessa área, já tem corpo docente qualificado para atuar nessa área, falta acho que, na verdade, uma organização desse grupo para propor um modelo: bom, essa área vai atuar desse ou daquele jeito, e implementar isso de fato.

\section{C.E.S.}

7) De que maneira as pesquisas em Práticas Interpretativas relacionam-se com as Áreas de Concentração e as Linhas de Pesquisa atuais?

\section{F.H.O.I.}

A gente tem duas Áreas de Concentração e duas Linhas de Pesquisa, uma área de concentração é Musicologia e a outra Processos de Criação Musical. Na prática isso significa a divisão entre uma área que lidaria mais com as questões teóricas e analíticas e outra com as questões mais voltadas para a prática instrumental e para a composição. Então, formalmente, essa divisão já existe e ela me parece até adequada. O que não acontece é uma... acho que o que faltaria de fato é você regular essa área de Práticas Interpretativas, porque aparentemente a estrutura do curso foi pensada para um curso voltado para a Musicologia, um curso voltado para questões teóricas, vamos dizer assim. Então esse curso contempla mal a área de Práticas Interpretativas, o que falta 
seria pensar quais seriam essas deficiências [demandas] para a área de Práticas Interpretativas e tentar implementá-las. Que tipo de formação a gente deveria oferecer, se o número de créditos é o mesmo, se a distribuição dos créditos é a mesma, se as exigências para se cumprir o mestrado e o doutorado seriam as mesmas que existem hoje. Então, vamos dizer, já existe a área, a maneira como a divisão é feita me parece adequada, mas ela não contempla as particularidades da área de Práticas Interpretativas como ela deveria contemplar.

\section{C.E.S.}

8) Como o Senhor considera que pesquisas em Práticas Interpretativas influenciam verdadeiramente na Performance?

\section{F.H.O.I.}

Como eu considero... não sei eu... na verdade estou tentando achar uma resposta inteligente para a pergunta. Mas acho que a pergunta, ela induz a algum, pode induzir a algum tipo de erro. Essa pergunta pode ser feita em qualquer área. Você fala assim: como a Musicologia ajudaria que a gente fizesse melhores músicas? (Seja lá o que isso quer dizer...) Acho que é uma questão relativa. Primeiro, a pós-graduação, ela, não necessariamente, precisa ter um caráter utilitário. Especialmente uma pós-graduação num curso de artes, dentro de uma universidade pública e com o perfil da USP. A gente tem várias áreas dentro da universidade que não atuam com essa perspectiva. Então, você está lidando com a idéia de formação, de ampliação, de desenvolvimento do conhecimento como um todo. Então, nesse sentido, não acho que a pesquisa em prática interpretativa precise se refletir diretamente e, vamos dizer, de maneira clara, na melhor performance de um determinado músico. Acho que buscar um perfil como esse é uma possibilidade, mas não é a possibilidade. Você pode pensar que um conhecimento mais sofisticado na área de práticas interpretativas, que venha de uma atividade de pósgraduação, possa gerar, por exemplo, melhores professores de música, possa gerar um conhecimento maior do que é o papel da música na sociedade, possa gerar um conhecimento maior de questões históricas e estilísticas dentro da música. E que, obviamente, tudo isso, em alguma medida, vai reverter para a performance musical, mas não da maneira direta e imediatista, no sentido: "esse mestrando entrou aqui, ele fez mestrado e fez o doutorado e agora ele toca melhor do que ele tocava antes”. Acho que essa perspectiva não é nem a que me seduz mais, para ser bem sincero. Acho que... na 
minha concepção, este papel seria um papel menor que um programa de pós-graduação em música, numa universidade como essa, poderia estar representando. Mas, não deixa de ser uma possibilidade, e mais uma vez eu volto à questão anterior: o próprio programa deveria discutir qual seria sua própria vocação, e eventualmente pode ser essa, um programa que tem uma pós-graduação que atua no sentido de um conservatório, não no sentido pejorativo do termo "conservatório", mas no sentido de um ensino do instrumento, da performance diretamente.

\section{C.E.S.}

9) Há um formato recorrente perceptível nas pesquisas que tratam das Práticas Interpretativas na USP?

\section{F.H.O.I.}

Não sei se eu consigo falar de maneira genérica [específica] sobre isso. É porque não é exatamente a minha área, embora eu tenha participado de muitas bancas, como Coordenador acabo acompanhando os títulos e as áreas das dissertações e teses, [mas] não é a área onde eu costumava estar transitando. Mas me parece, posso estar enganado, que há uma tendência dos trabalhos serem mais analíticos e há um grande dificuldade de se entender o que seria análise musical do ponto de vista da performance. Dentro do próprio programa tive a oportunidade de ver alguns trabalhos que conseguiam fazer isso bastante bem. O trabalho da Margarida Fukuda, por exemplo, que é um trabalho de análise de práticas interpretativas voltado para repertório específico, com metodologia específica e uma metodologia que pode ser utilizada para que o intérprete toque de uma outra maneira, melhor ou pior, mas, em geral, há uma confusão do que seria análise no contexto da prática interpretativa. Mas acho que essa questão analítica seria a mais busca, talvez, e talvez a mais infrutífera.

\section{C.E.S.}

10) Que importância o Senhor atribui à análise como ferramenta que ampara a interpretação?

\section{F.H.O.I.}

Bom, tem a análise musical, que eu acho que é fundamental para você... análise, vamos dizer, tradicional, no sentido formal, tonal, harmônica, etc., que é fundamental para 
você entender o material com que você está lidando como intérprete, e isso certamente vai determinar como você consegue lidar com uma determinada obra, um determinado repertório. Acho que essa análise é fundamental e ela é, vamos dizer, um pressuposto básico. $\mathrm{O}$ instrumentista deveria estar habilitado a conseguir fazer, pelo menos em algum nível elementar, esse tipo de análise. Análise interpretativa seria essa mesma análise em que o foco seriam as questões diretamente implicadas na interpretação. Isso é importante, isso é uma coisa que parece um pouco difícil de ser notada, de que toda a idéia de Musicologia, praticamente de Rameau para frente, ela é pensada do ponto de vista da composição. E, enquanto pensada do ponto de vista da composição, ela é pensada enquanto abstração. Então existe um processo, que vários teóricos até falam, desse descolamento do pensamento musical do fazer musical. Então você tem a música, você pode falar de música sem que exista som nenhum, por exemplo. Você pega uma partitura, você é capaz de dizer muita coisa sobre aquela partitura e em alguns momentos da própria história e em algumas áreas da própria Musicologia o que é tido como fundamental da música está contido ali. Então você pode achar ou advogar que a partitura tem alguma coisa essencial da música que independe da sua realização. Isso tem a ver um pouco com esse ponto de partida da composição, dessa abstração do pensamento musical, e assim por diante. O que eu acho que é importante é pegar o outro lado da moeda, que seria tentar achar dentro de um repertório elementos que implicam diretamente em problemas de performance. E, daí, acho que é onde a área ainda não conseguiu adquirir consistência, achar que tipos de problemas são esses e quais seriam as metodologias para lidar com esses problemas. Podem ser parecidas com a idéia de análise formal, mas não são a mesma coisa, tem que haver um outro tipo de procedimento.

\section{C.E.S.}

11) Como é visto pelo Senhor o fato de que instrumentistas, tanto professores quanto alunos, quando ligados à universidade, tenham que, de alguma maneira, relacionar sua interpretação às práticas acadêmicas?

\section{F.H.O.I.}

Por um lado isso reflete uma falta de alternativas, acho que determinado tipo de formação poderia... Tem duas maneiras de ver, uma seria assim: no Brasil e no mundo inteiro, mas falando do nosso caso em particular, no Brasil existe uma falta de 
alternativa para a formação do músico. Então ele se vê obrigado a entrar na universidade para suprir esta falta de alternativa, e ele entra num meio que não é o meio adequado para que ele faça isso. Então, o que ele tem que fazer é, vamos dizer, uma espécie de "prostituição" ali. Eu me "ajeito" dentro daquele sistema já que não tem um sistema melhor para que eu possa atuar. E, de certa forma, é como... puxa vida, "prostituição" é uma palavra um pouco forte nesse contexto, mas é um pouco o que acontece. Você tenta entrar num meio que não é o meio adequado, não foi pensado para isso, mas você não tem uma alternativa melhor. E a gente pode pensar que não é uma boa alternativa porque a pós-graduação, pensada como um todo, não [apenas] para a área de música, ela não é um lugar de formação "instrucional”, vamos dizer assim. Você pode ter várias etapas, você tem a pós-graduação lato sensu, que essa sim pode ser formadora, uma continuação, uma especialização do que você teve na graduação, por exemplo; mas no que a gente chama de pós-graduação stricto sensu, que é o mestrado e ou doutorado, a formação é essencialmente feita para que você se forme como pesquisador. O mestrado, teoricamente, seria para você aprender a fazer pesquisa, e o doutorado seria para você iniciar uma pesquisa que vai te qualificar como pesquisador. Nesse sentido, a pós-graduação não é o lugar para você ter um instrumentista. Primeiro porque não é lugar para você ter aulas de instrumento, você não tem aulas de temas específicos dentro da pós-graduação. Você tem temas mais gerais ou temas mais diversificados, que vão ser, de alguma maneira, usados para você aumentar o seu conhecimento, aprender a fazer pesquisa, etc., lidar com fontes, saber mapear o conhecimento, coisas desse tipo. Isso não tem nada a ver com aprender a tocar melhor ou com a prática de tocar melhor ou... enfim, esse seria um pensamento. Então a pósgraduação simplesmente não é o lugar adequado para esse tipo de coisa mas, por uma falta de alternativa melhor, você tem instrumentistas buscando dentro desse meio. A outra perspectiva seria você dizer: "Bom, a pós-graduação ela foi pensada a partir de um conhecimento científico, que inclusive esteve mais voltado às ciências "duras", física, engenharia, etc., e ela tem uma perspectiva que de certa forma é imposta a outras áreas que lidam com o conhecimento de uma outra maneira." Por exemplo, o caso da música, em que a idéia de pesquisa laboratorial, pesquisa de campo, etc., nem sempre se aplica àquela prática. Isso tem a ver não só com música, mas com outras carreiras como medicina, por exemplo, ou outras carreiras técnicas em que a pesquisa acadêmica, às vezes, não rende tanto quanto um trabalho técnico, por exemplo, como nas engenharias. E que seria o momento da própria pós-graduação rever o seu papel e se adaptar a 
demandas de áreas específicas. Acho que as duas posições têm a sua verdade, mas elas são problemáticas.

\section{C.E.S.}

12) Que papel ocupa o Programa de Pós-Graduação da USP em relação às outras universidades estaduais paulistas? Há um perfil específico?

\section{F.H.O.I.}

$\mathrm{Eu}$ acho que as três universidades tendem a se equilibrar, tanto nas áreas oferecidas quanto na qualidade, e isso é uma coisa recente, existia uma diferenciação muito grande há dez anos atrás. Não vou aqui entrar em questões de qualidade, etc., mas existiam diferenças claras entre os cursos das três universidades. Hoje, assim como as marcas de uísque, de vinho, de cerveja, os cursos também estão se homogeneizando, porque as regras são muito parecidas e o perfil do corpo docente é muito parecido. As áreas que... Talvez a diferença maior seja na UNICAMP, que tem também música popular, e alguma proximidade, talvez um pouco maior, na pós-graduação com os cursos das outras áreas: multimídia, eles têm cursos acho que [de] multimeios, os cursos de artes em geral. Então tem uma "miscigenação" ali qualquer, que diferencia um pouco, mas o curso de música da UNICAMP também, que era um grande curso de artes, também se subdividiu há poucos anos, então agora o curso de música também é um curso autônomo, acho que então [é] a tendência dos três cursos irem se homogeneizando e terem um perfil muito parecido. A diferença acaba sendo, isso é uma coisa natural da pós-graduação, que não acontece muito na graduação, a diferença acaba sendo na especificidade dos orientadores. Na pós-graduação você tem uma relação muito direta entre o aluno e o orientador. Na graduação você entra lá e você vai ter vários professores, vai passar por diversas disciplinas, em que você tem sempre um panorama de áreas. Na pós-graduação não, até porque você entra numa área específica, com orientador específico, esse orientador é que vai definir o seu percurso, existe uma relação muito grande entre projeto do aluno - projeto do orientador. Então, a diferença está quando o aluno procura um orientador numa das três universidades que é especialista numa área ou num tema em que ele tem interesse e que a outra universidade não tem especialista ou [tem] especialista com outro perfil que não atrai tanto. Tirando isso, acho que elas estão cada vez mais próximas. 


\section{C.E.S.}

13) Quais os principais desafios a serem ainda enfrentados pelo Programa de PósGraduação em Música da USP?

\section{F.H.O.I.}

Em relação ao corpo docente eu acho que ainda tem muito para se fazer em questão da pesquisa científica. A gente precisa ter mais projetos de pesquisa, no sentido tradicional, não artístico, mas no sentido de pesquisa acadêmica, que atraiam mais financiamento, não só pelo dinheiro trazido pelo financiamento, mas porque isso, na verdade, legitima os projetos e é uma espécie de... desencadeia outros projetos. Quando você tem um projeto apoiado pelo CNPq, pela FAPESP, pela CAPES, isso reverte em produção acadêmica, especialmente publicação, mais uma vez não só pelo número de publicações, mas porque essa publicação é que difunde o conhecimento que é produzido, e que permite que se olhe criticamente esse conhecimento. Então, se você tem um programa que produz... é como na produção artística: você pode ter um curso que ele é reconhecido, um curso de música que é reconhecido, que atrai alunos, que tem reconhecimento de outros cursos, porque os professores desse curso são reconhecidos como grandes artistas, etc. No lado acadêmico-científico é a mesma coisa, se você tem um curso em que o professores publicam, fazem pesquisa, isso também, quando você publica, faz pesquisa, você tem reconhecimento, tendo reconhecimento você passa a ser solicitado para dar parecer, para compor bancas, para fazer assessoria, etc. Então você interfere muito mais ou participa muito mais do meio acadêmico daquela área. Se você não tem essa produção, cada vez mais você fica isolado. Então acho que a gente avançou muitíssimo nos últimos anos, melhorou muitíssimo, mas ainda é muito pouco para a área. E eu acho que o programa está crescendo muito e muito rápido, então ele precisa se reestruturar, especialmente na questão das suas áreas. E, obviamente, neste sentido, duas áreas são... tem três áreas que precisam ser cuidadas. Talvez a mais emergencial seria Práticas Interpretativas, porque há muito já que ela deveria estar implementada, regulamentada; a segunda área que está começando a aparecer e ter produção que mereça alguma atenção especial é a Educação Musical; e talvez a terceira área seja a que a gente chama de Música e Tecnologia, que embora não tenha um lugar específico dentro da estrutura do programa, acaba tendo uma produção razoável, talvez fizesse com que ela tivesse uma Linha de Pesquisa, talvez, específica. 


\section{C.E.S.}

14) Qual é a avaliação geral que o Senhor faz do Programa desde a sua criação até os dias de hoje?

\section{F.H.O.I.}

Eu acho que o programa foi muito fechado em si mesmo até dois mil e pouco. O que quer dizer isso, que o programa tinha seu próprio modo de conduta, pouca atenção para o que se fazia fora do programa. No início do percurso, o programa estava muito fechado em si mesmo, com pouca atenção para fora, tanto para outros programas, quanto para outros professores, quanto para a própria CAPES. Isso teve algumas consequiências bastante negativas, eu acho. Primeiro que o programa deixou de perceber um crescimento de outros programas que tentaram se adaptar mais rapidamente, vamos dizer, às mudanças da pós-graduação no Brasil de maneira geral, e à quantidade crescente de exigências da CAPES, que é uma coisa assim realmente muito grande, todo mundo acaba questionando, etc., mas, de certa forma, ajudou a alavancar a pósgraduação no Brasil. E criou uma... acho que talvez a pior consequiência tenha sido o fato de que isso criou uma espécie de antipatia de outros programas em relação ao nosso. Isso é uma coisa delicada até de colocar, mas eu acho que é importante porque tem reflexos que são institucionais. A gente deixou de atrair melhores alunos e a gente deixou de oferecer condições melhores para os alunos que a gente tinha, em função disso. E o programa foi penalizado de diversas formas, inclusive na sua própria avaliação da CAPES. Porque a avaliação pela CAPES é feita... a CAPES não é uma entidade que está lá no céu, a CAPES ela é feita pelos representantes dos próprios programas, então a avaliação é feita pelos nossos pares. Se existia essa antipatia pelo programa e não existia uma vontade do programa de sanar essa visão negativa que existia sobre a gente, isso teve uma série de reflexos, inclusive na própria avaliação que começou a ser negativa. Obviamente era negativa também por problemas concretos, existentes, mas também existia uma dose de desconhecimento da realidade, e um pouco talvez de subjetividade, quem sabe, nessa avaliação. E com isso o programa foi muito penalizado. E esse é um tipo de coisa que você demora muito tempo para reverter. Você demora, isso não é coisa: "Bom, de agora para frente a gente vai ter uma outra atitude", não é assim, você demora anos para reverter essa situação. Eu acho que foi o que a gente tentou fazer, sei lá, de 2005 para frente, mais ou menos. Reverter um pouco a 
visão externa que existia em relação ao programa e melhorar a relação do programa com a pós-graduação em geral, dentro e fora da USP. Então acho que hoje isso também se reflete num salto qualitativo muito grande, com mais intercâmbio você areja o programa, você abre novas perspectivas e você também recebe informação, conhecimento que vem de fora, o que é sempre positivo. Então acho que isso faz parte também desse processo de crescimento recente que a gente teve.

\section{C.E.S.}

15) Que outras informações o Senhor gostaria de acrescentar?

\section{F.H.O.I.}

Acho que nenhuma. Acho que falei bastante, acho que tem... não me lembro nada assim especialmente nessa área, ligado às Práticas, nada que seja muito relevante que eu não tenha dito. Eu acho que, não em relação ao programa, mas em relação ao trabalho, uma sugestão, talvez, é que você confronte de fato os problemas do programa ou das três universidades com o que se faz nos outros lugares do Brasil. Porque eu diria que, numa certa medida, São Paulo demorou mais ou está demorando mais para entrar nessa área do que outros lugares. A gente tem desde experiências antigas, mais consolidadas, como o Rio Grande do Sul ou a UNIRIO, que já têm essas áreas há bastante tempo, [até] outras áreas mais novas, eu acho que Goiânia, se não me engano, tem um programa em Práticas, Belo Horizonte tem um programa muito consistente nessa área. Então, mesmo para que a gente se organize, vamos supor a eventualidade do programa tentar organizar essa área, é fundamental partir da experiência desses programas que já existem há alguns anos, e que já foram inclusive avaliados nessas áreas. Então eles já criaram seus cursos, já formaram alunos e já receberam avaliações, críticas, sugestões. Já tiveram tempo de implementar essas críticas, sugestões e já estão reavaliando. Então acho que seria importante fazer um contraponto, não só entre as três universidade paulistas, mas também em relação às outras universidades que estão fora. Acho é isso.

\section{C.E.S.}

Obrigada pela entrevista. 


\begin{abstract}
ANEXO III
Entrevista com a Prof ${ }^{a}$ Dr $^{\text {a }}$ Adriana Giarola Kayama, realizada no dia 17 de agosto de 2009, por telefone (transcrição literal).

\section{Cláudia Elena Siste}

1) Como começou o Programa de Pós-Graduação em Música da UNICAMP? Quais os principais professores que atuaram no início?

\section{Adriana Giarola Kayama}

O Programa de Pós-Graduação em Música, na realidade, teve um embrião anterior que era o Programa de Pós-Graduação em Artes, onde tínhamos artes cênicas, artes corporais, artes plásticas e música, tudo junto. Por recomendação da CAPES, insistentes recomendações, por vários anos, a gente resolveu desmembrar a música do resto das artes, mesmo porque a indicação da CAPES era de que a música estava desequilibrando artes como um todo, porque ela tinha uma produção muito grande e muito específica, numa direção, e o resto do programa tinha uma produção mais equilibrada e mais heterogênea. Então isso estava dando um problema na avaliação. Então a recomendação foi que a música se desmembrasse do Programa de Artes, e isso finalmente foi acatado dentro do Instituto, pela Universidade, em 1999. E, quando a gente desmembrou, a gente já criou, junto com o Mestrado, o Doutorado. Então quando a gente desmembrou das Artes em 1999, a gente já abriu dois cursos, de Mestrado e Doutorado.
\end{abstract}

\title{
C.E.S.
}

2) Que premissas foram apresentadas à Universidade para a criação do Programa?

\section{A.G.K.}

Buscando a integração das diferentes áreas de atuação da música, tentando preservar a realização musical, ou seja, que a realização musical tivesse fortemente presente, seja ela nessa própria área performática, seja ela através de uma produção, de uma criação artística que fosse levada à cena, que fosse ao palco. Uma produção de musicologia, 
enfim, toda essa produção que tivesse um retorno ou um envolvimento musical, de fato, que não ficasse apenas na teoria, que havia uma prática atrelada a ela.

\section{C.E.S.}

3) Quais as Áreas de Concentração e Linhas de Pesquisa predominantes desde a criação do Programa?

\section{A.G.K.}

O programa foi criado sem Áreas de Concentração. Ela [ele] foi, na realidade, na época, concebida [o] como um programa com três Linhas de Pesquisa: Processos Criativos, Práticas Interpretativas e Fundamentos Teóricos. No transcorrer dos anos seguintes, a gente chegou à conclusão que essas não eram, de fato, Linhas de Pesquisa, mas sim Áreas de Concentração. Então hoje nós temos essas Áreas de Concentração e Linhas de Pesquisas que em alguns casos até atravessam diferentes Áreas de Concentração. Eu não tenho "de cabeça" e eu não tive tempo hoje de verificar quais são exatamente as Linhas de Pesquisa hoje, mas elas um pouco que atravessam as diferentes Áreas de Concentração.

\section{C.E.S.}

4) Quais as principais transformações que o Programa sofreu desde a sua implantação?

\section{A.G.K.}

Bom, essa é exatamente uma delas. A própria estrutura ficou... foi alterada um pouco. Enquanto programa, a transformação acho que maior foi nessa linha, da questão da estrutura propriamente dita, que bate um pouco mais no próprio funcionamento do programa. Eu não posso dizer que essas mudanças afetaram o tipo de candidato que entra ou as áreas dos projetos que entraram no programa, mas sim mais o funcionamento, a reorganização, a reestruturação dele nesse sentido, nos seus alicerces de funcionamento. E nós temos estimulado, cada vez mais, a produção, a produção artística e a produção bibliográfica, dos docentes e dos discentes. Mas isso é uma coisa que a gente já vinha fazendo e a gente mantém ainda, esse esforço em aumentar a nossa produção. 


\section{C.E.S.}

5) Como a Senhora considera o desenvolvimento do Programa no que diz respeito à qualidade e quantidade das pesquisas realizadas?

\section{A.G.K.}

É uma resposta difícil, não? Eu acho que tanto a quantidade quanto a... [qualidade], tanto uma quanto a outra, eu acho que tem sido, assim, de alto nível. A quantidade, em particular, eu acho que chegou um momento de saturação. Nós começamos a receber muitos candidatos, muitos alunos, e o nosso corpo docente vem, assim, aos poucos, diminuindo de tamanho por aposentadorias. Eu acho que na área de pós-graduação a gente não teve nenhum falecimento, mas nós tivemos algumas perdas com aposentadorias e temos mais à vista. Então, a quantidade, nós nos demos conta de que se a gente não segurasse um pouco os ingressantes, a gente estaria saturando o programa, a gente estaria indo um pouco além da capacidade de comportar esses alunos, de atender esses alunos. Quanto à qualidade, isso tem sido... a avaliação da CAPES tem sido muito positiva nesse sentido, e a produção... uma coisa que sempre chama muito a atenção é essa possibilidade de a gente atrelar, não só nas áreas performáticas, mas na própria criação, na própria... nos fundamentos teóricos, em muitos trabalhos a gente tem uma produção artística vinculada. Seja ela pelo próprio aluno, ou seja produzindo isso com outros colegas, com outros grupos que regem, enfim. Mas, isso é uma característica muito forte, e tem dado um resultado muito positivo, nesse sentido. Outra coisa é a própria inserção no mercado dos nossos alunos. Esses alunos têm uma inserção bastante significativa no mercado acadêmico. Nós temos ex-alunos e alguns alunos, mas muitos ex-alunos atuando em universidades federais e escolas estaduais também.

\section{C.E.S.}

6) Qual a importância que a Pesquisa em Práticas Interpretativas ocupa atualmente no Programa de Pós-Graduação da UNICAMP?

\section{A.G.K.}

A área de Práticas Interpretativas é muito forte na UNICAMP, sempre foi. A preocupação nossa sempre foi de equacionar essa produção artística ao pensar e à sistematização, à reflexão sobre essa produção. Agora, sem dúvida, a [área de] Práticas Interpretativas, seja ela enquanto Área de Concentração, como ela é hoje, mas seja ela 
como produto também de outras Áreas de Concentração, ela é muito forte. É uma coisa, é uma característica emblemática da nossa pós-graduação, essa preocupação com a produção artística, ou a práxis interpretativa vinculada a essa reflexão.

\section{C.E.S.}

7) De que maneira as pesquisas em Práticas Interpretativas relacionam-se com as Áreas de Concentração e as Linhas de Pesquisa atuais?

\section{A.G.K.}

Bom, Práticas Interpretativas de fato é uma Área de Concentração em si, do nosso programa. Mas, como eu estava dizendo, nós temos diferentes Linhas de Pesquisa, dentro da área de Concentração de Práticas Interpretativas, e também nós temos algumas Linhas de Pesquisa nas outras Áreas de Concentração nas quais você tem a possibilidade de ter como produto complementar, ou um produto, vamos dizer, paralelo, não é muito correto isso, mas como produto... a própria produção artística. Então ela existe enquanto Área de Concentração por si, mas ela também existe como parte de um resultado nas outras Áreas de Concentração também.

\section{C.E.S.}

8) Como a Senhora considera que pesquisas em Práticas Interpretativas influenciam verdadeiramente na Performance?

\section{A.G.K.}

Olha, eu acho que a questão da pesquisa em Práticas Interpretativas traz um tipo de reflexão, um tipo de compromisso com o fazer artístico, o fazer artístico refletido, refletido historicamente, refletido analiticamente; a produção, ela ganha uma... um... peso não é a palavra certa, mas ela ganha elementos a mais, que justifiquem a sua compreensão daquela obra. Passa um pouco, transcende o "eu gosto de", "o fulano faz assim e eu também gosto", é uma questão do refletir na estrutura, na composição, na concepção, na questão histórica, e traz elementos que agregam, que complementam nesse fazer artístico. 


\section{C.E.S.}

9) Há um formato recorrente perceptível nas pesquisas que tratam das Práticas Interpretativas na UNICAMP?

\section{A.G.K.}

Agora me lembrei, eu olhei essa questão e fiquei pensando um pouquinho, durante o dia. Eu não acho que tem uma... pelo que eu estou entendendo da sua questão, eu não acho que tem um tipo de olhar nas áreas performáticas, [se] é isso que você está perguntando. Eu acredito que nós temos as abordagens mais diversas. Não pode se esquecer que também nós temos a música popular, e inclusive o fazer artístico dentro da música popular. Então, eu não consigo perceber um formato recorrente, realmente não. Se existe algum tipo de formato recorrente, talvez seria a produção artística desse aluno ser bastante voltada para aquilo que ele está pesquisando naquele momento, mas isso não pode ser considerado como um formato. As produções são muito variadas, realmente são muito variadas, são olhares, até entre os próprios docentes, seus orientandos, são muito diversas. É uma coisa que inclusive atrapalha um pouco a concepção de um grupo de pesquisa, porque a gente acaba, pelo menos falo por mim aqui, a gente acaba abarcando uma produção muito diversa e acaba prejudicando um foco mais fechado, num assunto mais específico, numa pesquisa mais fechada. Então, não estou querendo dizer com isso que a pesquisa é toda dispersa, mas você ter uma linha de..., um formato, uma abordagem mais cercada, isso nós não temos. E eu acho que seria até um luxo no Brasil ainda a gente pensar numa pós-graduação muito fechada, muito hermética, diante de necessidades tão diversas e tão grandes, dentro da pesquisa em música. Então eu não consigo ver nenhum formato específico dentro da UNICAMP e acho difícil a gente, pelo menos nesse momento, pensar nisso, porque a demanda é muito grande.

\section{C.E.S.}

10) Que importância a Senhora atribui à análise como ferramenta que ampara a interpretação?

\section{A.G.K.}

A importância é enorme. Aliás, eu estou dando um curso nesse semestre exatamente sobre diferentes aspectos analíticos voltados à performance. Então eu acho que é 
fundamental a análise. Agora, depende que repertório, que linha analítica você vai seguir. Mas, certamente a análise musical é primordial para você fundamentar uma interpretação.

\section{C.E.S.}

11) Como é visto pela Senhora o fato de que instrumentistas, tanto professores quanto alunos, quando ligados à universidade, tenham que, de alguma maneira, relacionar sua interpretação às práticas acadêmicas?

\section{A.G.K.}

Eu já fui em todas as direções com essa questão. Eu já, em alguns momentos, resisti muito a essa produção acadêmica. Aí, por outro lado, fui na outra direção e valorizei demais a produção acadêmica em si, e deixei a artística de lado. Hoje em dia, com a convivência, com a experiência e com a vivência, eu percebo que as duas coisas são importantes, e não vejo como priorizar uma sobre a outra. Eu acho que priorizar no sentido de eu me definir enquanto musicólogo [a], enquanto... se eu sou da área de performance, sim, mas a minha produção não pode ser exclusivamente de um ou de outro. E a gente tem uma, eu sinto que, na UNICAMP, a gente tem uma relação bastante saudável entre essas duas produções, tanto entre os docentes e pelos próprios docentes, por docentes, por cada docente. Eu acho uma convivência saudável, você ter essa preocupação acadêmica e essa preocupação performática. Eu acho que elas se complementam.

\section{C.E.S.}

12) Que papel ocupa o Programa de Pós-Graduação da UNICAMP em relação às outras universidades estaduais paulistas? Há um perfil específico?

\section{A.G.K.}

Essa também foi difícil, difícil a gente falar. Eu acho que a UNICAMP, junto com as outras universidades paulistas, nós temos tido nos últimos anos uma troca de experiência, uma troca de docentes, assim, bastante saudável. Talvez, acho que uma característica particular da UNICAMP, não que as outras universidades não tenham, mas é uma característica muito forte da própria UNICAMP, é o fato da presença da música popular. Não necessariamente com aquele perfil etnomusicológico, mas com a 
produção de uma música popular, a música popular brasileira, não exclusivamente música popular brasileira, mas a música popular no seu fazer, na sua história, ela está bem presente também no programa. Eu não sei se daria para... eu não tenho números na cabeça, não chega acho que a 50\% erudito e 50\% popular, mas é uma porcentagem bastante alta de uma produção de uma área de pesquisa, ou melhor, de pesquisa dentro da música popular. Então talvez essa seja uma distinção entre as duas universidades, entre as três, aliás, mas nós temos tido uma troca de experiência, tanto com docentes da UNESP, com alunos, eu pessoalmente tive experiência de alunos meus assistirem, fazerem algumas disciplinas na UNESP e vice-versa. Então essa troca tem sido bastante saudável. Não sei se eu respondi à pergunta.

\section{C.E.S.}

13) Quais os principais desafios a serem ainda enfrentados pelo Programa de PósGraduação em Música da UNICAMP?

\section{A.G.K.}

Bom, essa é a minha opinião. Eu acho que uma coisa que eu acho que nós vamos ter que pensar, e já estamos começando a identificar, é a necessidade de cercar mais os projetos, em função, os projetos dos alunos, em função de um projeto do docente. Alguns docentes têm isso um pouquinho mais desenvolvido já, outros não. Mas eu acho que para o bem do programa e para a gente realmente ter um direcionamento mais claro dos projetos de pesquisa individuais, dentro de um temático maior, coordenado por um docente, por um grupo de docentes, essa necessidade talvez de focalizar um pouco mais o perfil, o objetivo das pesquisas. É o que eu sinto nesse momento.

\section{C.E.S.}

14) Qual é a avaliação geral que a Senhora faz do Programa desde a sua criação até os dias de hoje?

\section{A.G.K.}

Eu acho que o programa vem apurando ou depurando a sua estrutura, o seu oferecimento de disciplinas, os próprios projetos que são desenvolvidos dentro do programa. Eu percebo assim que o nosso processo seletivo está muito mais eficiente, está muito mais objetivo, mais claro e mais eficiente na sua aplicação. As disciplinas 
oferecidas têm sido melhor direcionadas à demanda dos próprios alunos. Não que a gente tenha que atender a essa demanda direta, mas nós tivemos um momento no começo, não da música, mas quando a gente estava no mestrado em artes como um todo, as disciplinas eram muito distantes de alguns dos projetos, de alguns dos interesses dos alunos. Então, isso tem melhorado também bastante. Eu acho que os alunos conseguem aproveitar das disciplinas, aproveitar, direta ou indiretamente, esse conhecimento na sua pesquisa. Então isso, é exatamente isso um dos objetivos do oferecimento dessas disciplinas. E, acho que, basicamente, é isso aí, deixe eu ver, deixe eu relembrar a pergunta aqui... É, a projeção também dessa produção, nós temos conseguido cada vez mais, apesar de precisarmos trabalhar melhor isso e investir mais nisso, mas nós estamos conseguindo cada vez mais levar essa produção para fora, tanto a acadêmica, quanto a artística, ou conjuntamente, levar para os congressos, a gente está tendo uma participação cada vez maior em congressos, tanto nacionais quanto internacionais. Então acho que a gente está conseguindo.

\section{C.E.S.}

15) Que outras informações a Senhora gostaria de acrescentar?

\section{A.G.K.}

Eu acho que a gente já esgotou bastante o assunto. Em relação à pesquisa, tem alguns momentos que eu percebo que é mais em função do programa, coisas mais objetivas, e alguns outros momentos são realmente opiniões mais pessoais. Eu acho importante deixar claro que eu não sou coordenadora do programa. Eu fui, na sua criação, coordenadora do programa, e hoje eu faço parte da comissão da pós-graduação, mas não sou coordenadora. Então, possivelmente eu posso estar refletindo uma opinião pessoal, mas que pode não estar refletindo a vontade desse coordenador, ou que esse futuro coordenador (nós estamos exatamente numa mudança agora), almeje para o programa. Acho que isso é importante deixar claro. E é isso.

\section{C.E.S.}

Obrigada pela entrevista. 